\title{
ESTUDO COMPARATIVO DA CULTURA ORGANIZACIONAL ENTRE A ÁREA DE VENDAS E AS ÁREAS DE SUPORTE DE UMA EMPRESA DE GRANDE PORTE
}

\section{Ana Caroline de Souza Kozlowski}




\title{
ESTUDO COMPARATIVO DA CULTURA ORGANIZACIONAL ENTRE A ÁREA DE VENDAS E AS ÁREAS DE SUPORTE DE UMA EMPRESA DE GRANDE PORTE
}

\section{Ana Caroline de Souza Kozlowski}

\author{
Professora Orientadora: \\ Prof ${ }^{a}$ Dra. Maria de Fátima Bruno de Faria
}

"Trabalho apresentado em cumprimento às exigências acadêmicas parciais da disciplina Estágio Supervisionado em administração para a obtenção do grau de Administradora" 
Kozlowski, Ana Caroline.

Estudo comparativo da cultura organizacional entre a área de vendas e as áreas de suporte de uma empresa de grande porte / Ana Caroline Kozlowski. - 2009.

73 f. : il.

Monografia (Graduação) - Universidade de Brasília, Departamento de Administração, 2009.

Orientação: Prof. Dra . Maria de Fátima Bruno de Faria, Departamento de Administração

1. Administração. 2. Gestão de Pessoas. 3. Cultura Organizacional. I. Título. 
Universidade de Brasília

Faculdade de Economia, Administração, Contabilidade e Ciências da Informação e Documentação

DEPARTAMENTO DE ADMINISTRAÇÃO

ESTUDO COMPARATIVO DA CULTURA ORGANIZACIONAL ENTRE A ÁREA DE VENDAS E AS ÁREAS DE SUPORTE DE UMA EMPRESA DE GRANDE PORTE

A Comissão Examinadora, abaixo identificada, aprova o Trabalho de Conclusão do Curso de Administração da Universidade de Brasília da aluna

\section{Ana Caroline de Souza Kozlowski}

Maria de Fátima Bruno de Faria, Dr ${ }^{\mathrm{a}}$

Professora-Orientadora

Domingos Spezia, MSc.

Professor-Coordenador

Brasília, 7 de julho de 2009 
Aos meus pais, pelo apoio que me deram antes de entrar na UnB e, ao longo do meu curso, pelo esforço que sempre tiveram para proporcionar uma vida melhor à nossa família e por sempre acreditarem em mim e no meu potencial.

Ao meu namorado, Hermanno Ribeiro, que sempre esteve do meu lado me apoiando, me ajudando e me incentivando a tornar uma pessoa e uma profissional melhor a cada dia.

À minha amiga, Clarissa Schmidt, companheira em todos os momentos vividos na UnB e essencial no desenvolvimento do projeto de monografia.

A empresa na qual trabalho, local onde a Cultura Organizacional é incrível, e por isso, foi a inspiração para o tema dessa monografia. 


\section{AGRADECIMENTOS}

À gerência da empresa pesquisada, por acreditar no meu trabalho e ter proporcionado a realização dessa monografia.

Aos funcionários da empresa pesquisada, por tornarem possível o desenvolvimento da monografia respondendo o questionário.

À Professora Doutora Maria de Fátima Bruno de Faria, pela excelente orientação, disponibilidade, ajuda e transmissão de conhecimento.

À AD\&M Consultoria Empresarial, por toda a aprendizagem, formação, feedback, desafios, contribuição e desenvolvimento proporcionados.

À minha turma de Administração ( $2^{\circ}$ semestre de 2005), em especial, Vitor, Clarissa, Lucas, Gabriela, Dandara, Hermanno, Michel, Marcos, Matheus, Henrique, Braulio, Felipe e Renaud, que durante todo o curso ajudaram na minha formação por meio de discussões enriquecedoras e compartilhamento de conhecimento.

À minha avó Anna e à minha família, por sempre acreditarem em mim e me proporcionarem meios para conquistar o que queria. 


\section{RESUMO}

Este trabalho teve como objetivo comparar a percepção de profissionais da área fim e das áreas de suporte de uma empresa de grande porte em relação à cultura organizacional. A cultura é formada por valores e práticas do dia-a-dia que podem ser percebidos ou não pelos funcionários. Os valores, definidos pelo instrumento utilizado, são: profissionalismo cooperativo, profissionalismo competitivo e individualista e satisfação e bem-estar dos empregados. E as práticas são: integração externa, recompensa e treinamento e promoção do relacionamento interpessoal. Com base na literatura sobre o tema e a partir de Instrumento Brasileiro para Avaliação da Cultura Organizacional (IBACO), foi possível realizar a pesquisa sobre o tema na organização escolhida. A metodologia de pesquisa teve caráter misto, sendo parte dela qualitativa e parte, quantitativa. A pesquisa qualitativa forneceu informações sobre a cultura da empresa por meio da pesquisa documental. Já a pesquisa quantitativa utilizou a técnica de levantamento de dados, survey, por meio de um questionário validado cientificamente, o IBACO. A população era de 200 funcionários, sendo que 53 deles responderam o questionário. As estatísticas utilizadas para análise dos resultados foram média, desvio-padrão e as correlações de Pearson. De acordo com os resultados obtidos, as médias finais dos fatores variaram de 3,40 a 4,11 em um intervalo de 1 a 5 . Isso indica que o valor Profissionalismo cooperativo e a prática Integração externa são fatores da cultura da empresa bastante aplicáveis à realidade e, portanto, estão mais disseminados, percebidos e compartilhados pelos seus membros. Os fatores Satisfação e bemestar dos empregados e Recompensa e treinamento foram avaliados como razoavelmente presentes, podendo, então, ser melhor desenvolvidos. E, por fim, a prática Promoção do relacionamento interpessoal e o valor Profissionalismo competitivo e individualista foram os que apresentaram menores médias. Pode ser interessante para empresa que o valor Profissionalismo competitivo e individualista esteja menos presente, porém a prática Promoção do relacionamento interpessoal avaliada como pouco presente precisa ser trabalhada pela organização. Observouse também que a área de Recursos Humanos foi a que apresentou melhores resultados, seguida da área de Vendas (área fim) e logo depois, Marketing. As demais apresentaram menores médias e por isso, precisam desenvolver tais valores e práticas da cultura da empresa.

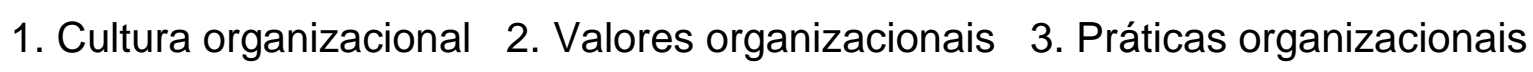




\section{SUMÁRIO}

1. INTRODUÇÃO

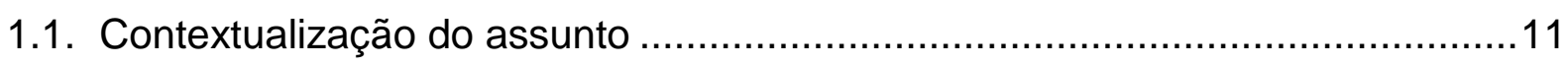

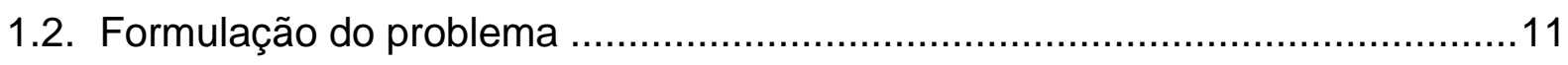

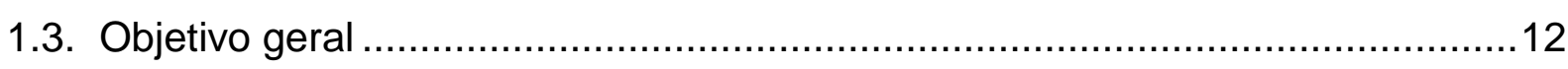

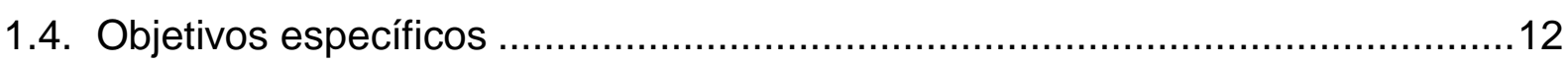

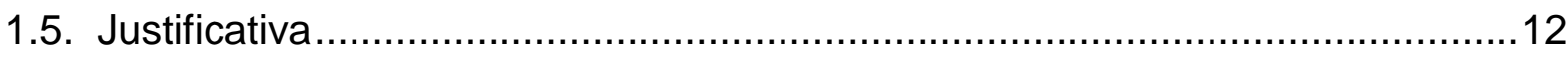

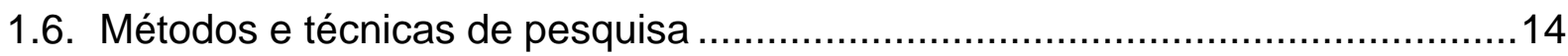

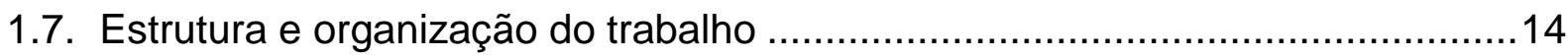

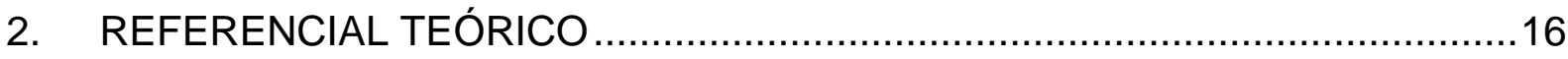

2.1. Conceitos e definições de cultura organizacional.........................................16

2.2. Diferentes abordagens de cultura organizacional .........................................19

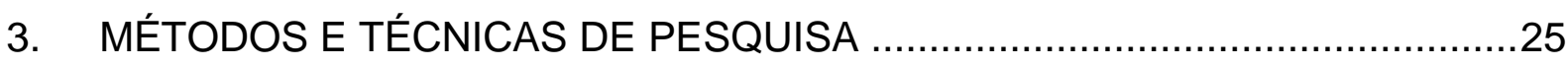

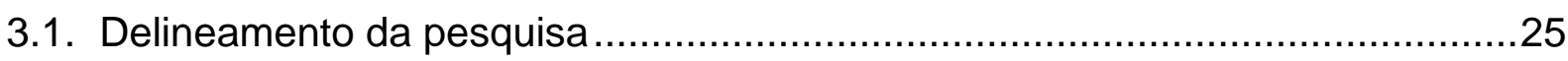

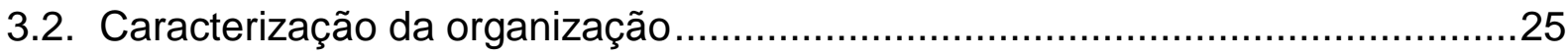

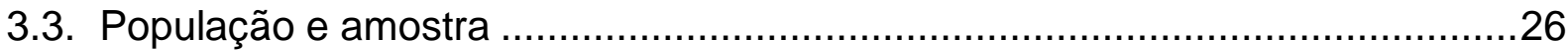

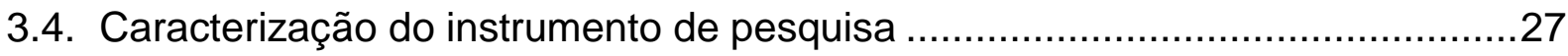

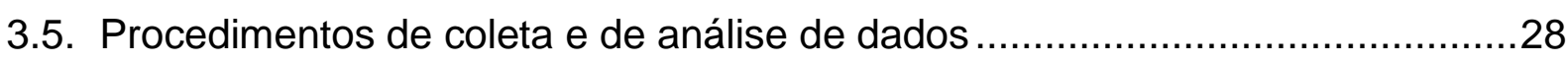

4. APRESENTAÇÃO E DISCUSSÃO DOS RESULTADOS DA PESQUISA .........31

4.1. Cultura organizacional para a empresa.......................................................

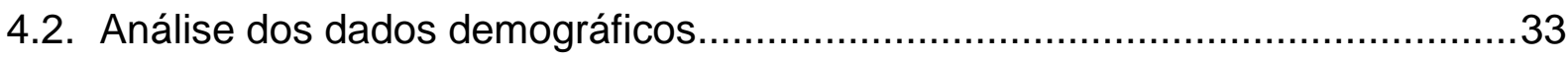

4.3. Resultados e análise dos fatores de cultura organizacional............................37

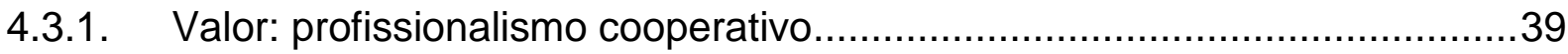

4.3.2. Valor: satisfação e bem-estar dos empregados ..........................................42

4.3.3. Valor: profissionalismo competitivo e individualista....................................46

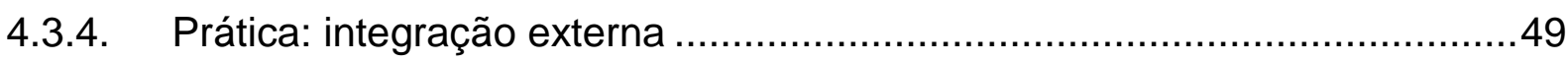

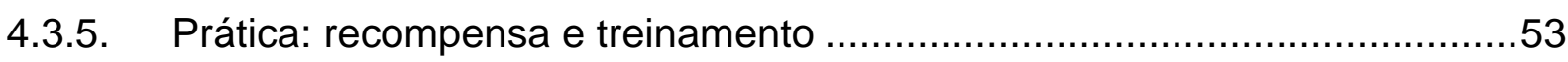

4.3.6. Prática: promoção do relacionamento interpessoal .................................57

4.4. Correlações entre fatores e dados demográficos ..........................................60

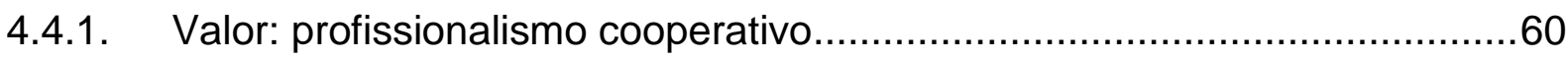

4.4.2. Valor: satisfação e bem-estar dos empregados ..........................................

4.4.3. Valor: profissionalismo competitivo e individualista...................................62 


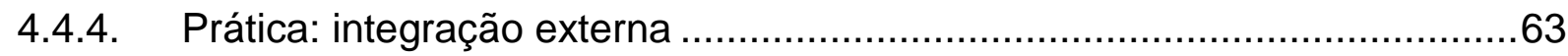

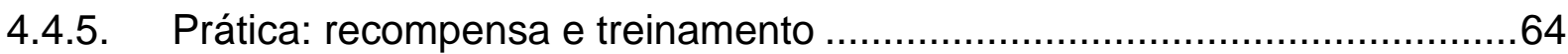

4.4.6. Prática: promoção do relacionamento interpessoal ..............................65

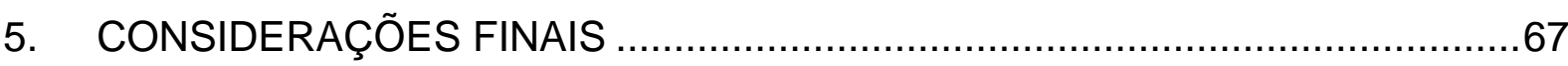

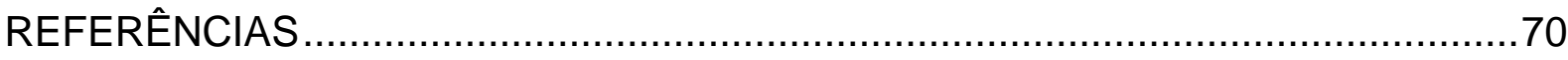

ANEXO A: Instrumento Brasileiro para Avaliação da Cultura Organizacional (IBACO) 


\section{LISTA DE ILUSTRAÇÕES}

Gráfico 1 - Distribuição dos funcionários por área ……......................................... 33

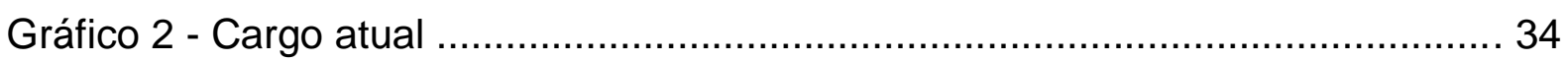

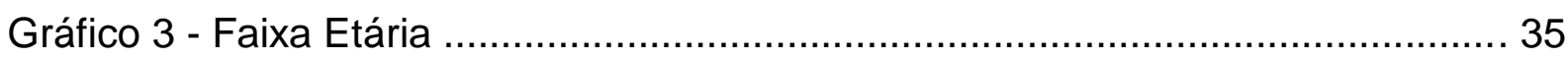

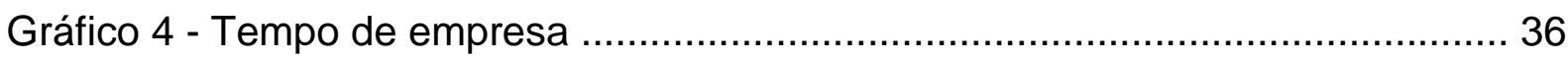

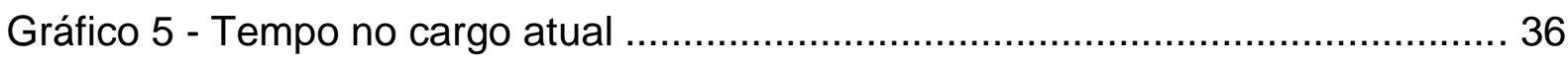

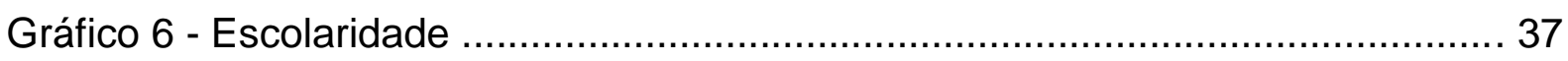

Gráfico 7 - Percentuais do item 17 ............................................................. 40

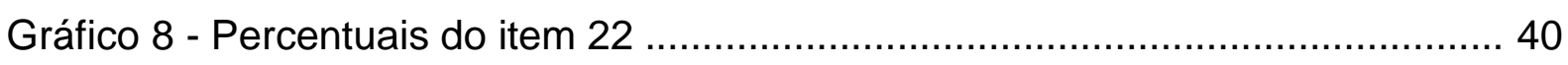

Gráfico 9 - Percentuais do item 14 ............................................................. 41

Gráfico 10 - Percentuais do item 21 ............................................................. 41

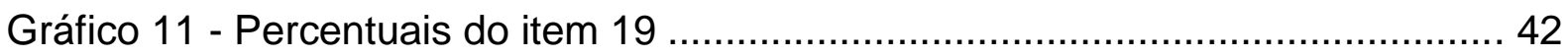

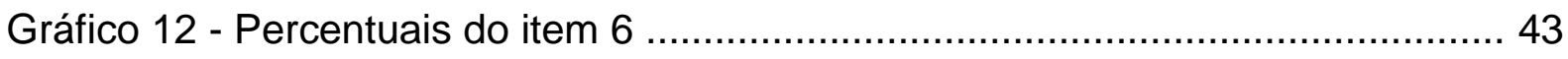

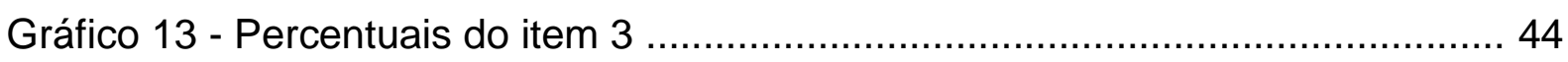

Gráfico 14 - Percentuais do item 12 ............................................................ 44

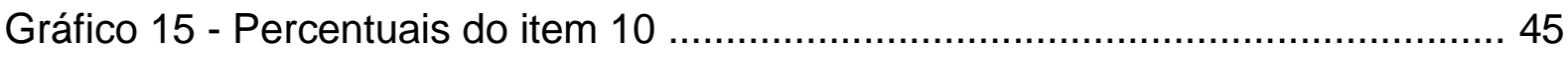

Gráfico 16 - Percentuais do item 18 ............................................................ 45

Gráfico 17 - Percentuais do item 25 .......................................................... 47

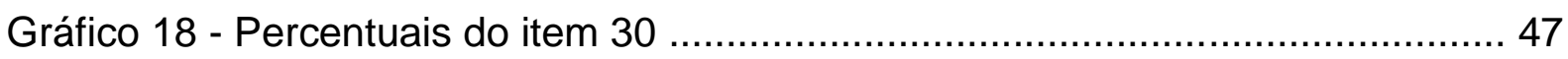

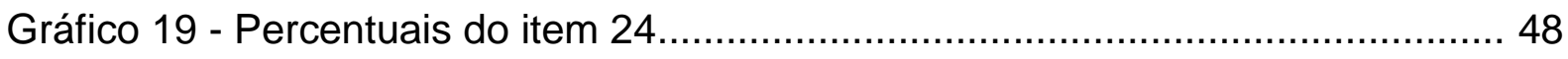

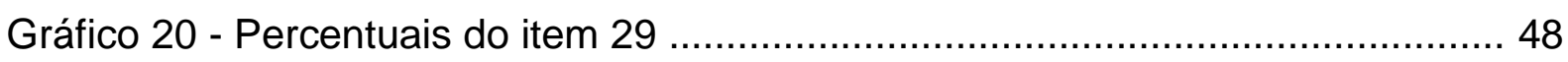

Gráfico 21 - Percentuais do item 23 ............................................................ 49

Gráfico 22 - Percentuais do item 4 .............................................................. 51

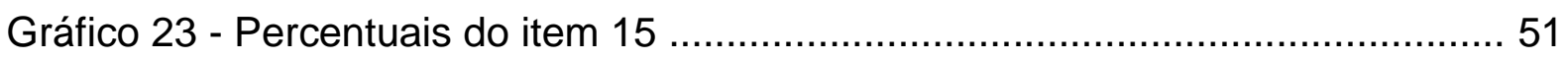

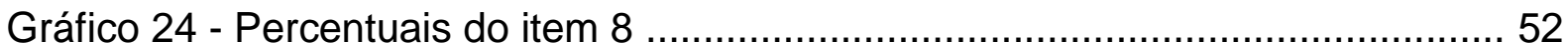

Gráfico 25 - Percentuais do item 2 ............................................................. 52

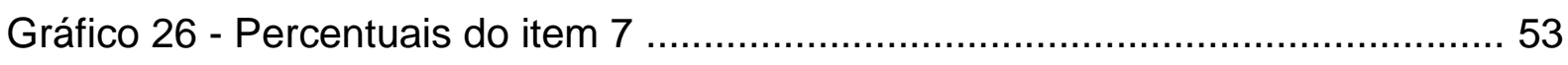

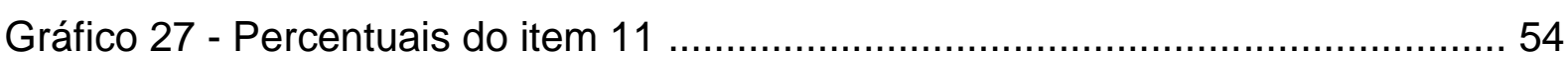

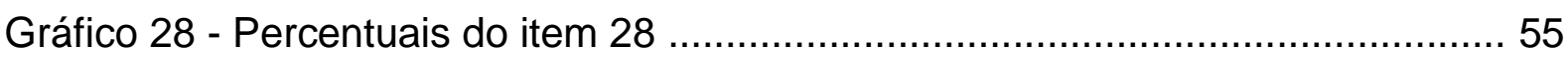

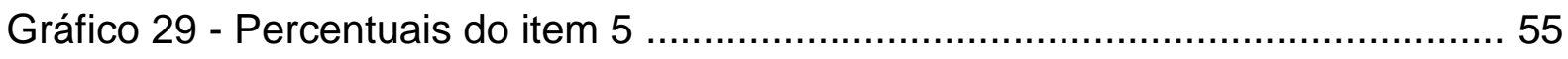

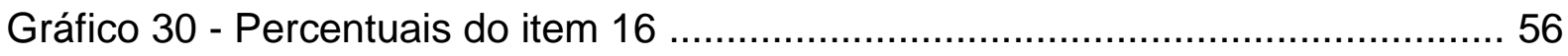

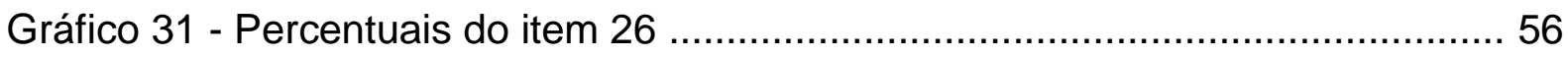

Gráfico 32 - Percentuais do item 13 ............................................................. 58 


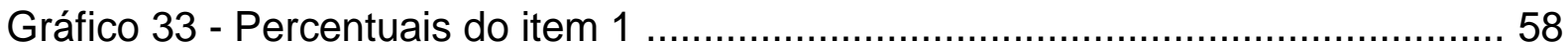

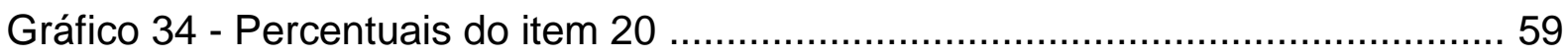

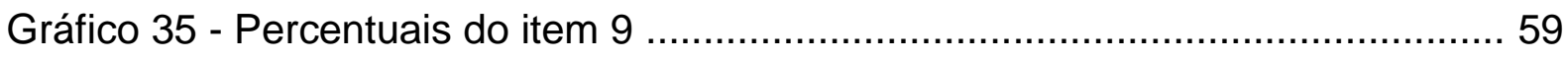

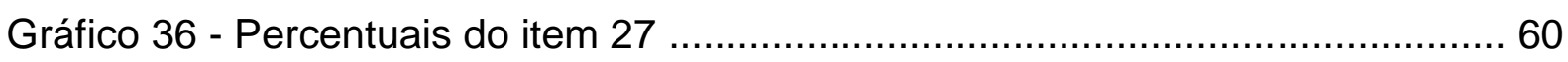

Gráfico 37 - Média das áreas para o fator Profissionalismo cooperativo ................ 60

Gráfico 38 - Média das áreas para o fator Satisfação e bem-estar dos

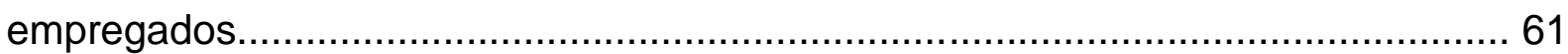

Gráfico 39 - Média das áreas para o fator Profissionalismo competitivo e

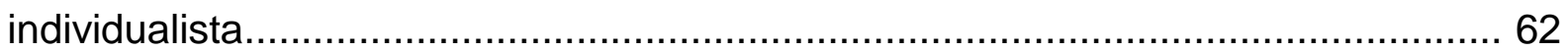

Gráfico 40 - Média das áreas para o fator Integração externa ............................... 63

Gráfico 41 - Média das áreas para o fator Recompensa e treinamento .................. 64 Gráfico 42 - Média das áreas para o fator Promoção do relacionamento interpessoal. 65 


\section{LISTA DE TABELAS}

Tabela 1 - Distribuição dos funcionários por área ........................................... 34

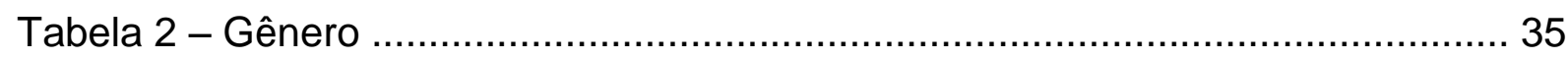

Tabela 3 - Médias e desvios padrão dos itens que compõem 0 dados

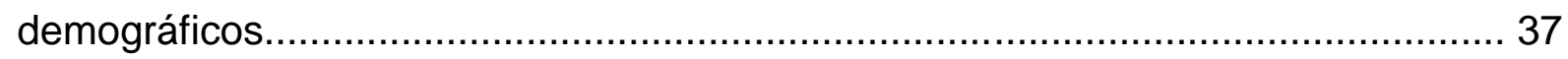

Tabela 4 - Médias e desvios padrão dos fatores de cultura organizacional de acordo com o IBACO 38

Tabela 5 - Médias e desvios padrão dos itens que compõem o fator profissionalismo cooperativo 39

Tabela 6 - Médias e desvios padrão dos itens que compõem o fator satisfação e bem-estar dos empregados

Tabela 7 - Médias e desvios padrão dos itens que compõem o fator profissionalismo competitivo e individualista 46

Tabela 8 - Médias e desvios padrão dos itens que compõem o fator integração externa 50

Tabela 9 - Médias e desvios padrão dos itens que compõem o fator recompensa e treinamento.

Tabela 10 - Médias e desvios padrão dos itens que compõem o fator promoção do relacionamento interpessoal 


\section{INTRODUÇÃO}

\subsection{Contextualização do assunto}

É vasto o número de estudos realizados acerca do tema "cultura organizacional", que, por sua vez, é relacionado a uma série de outros aspectos organizacionais como gestão do conhecimento, comunicação, desempenho.

A cultura de uma organização é vital para a continuidade e alcance de seus objetivos, pois faz com que todos estejam em uma mesma direção. Ela mostra como devem agir e que valores devem ter e partilhar. Para isso, é importante que todos percebam a organização de uma mesma forma.

A cultura organizacional refere-se à maneira pela qual os funcionários percebem as características da cultura da empresa, e não ao fato de gostarem ou não delas (ROBBINS, 2005, p.376).

Com isso identifica-se a necessidade de avaliar como essa cultura está disseminada dentro dos diferentes níveis da organização e das diferentes áreas, uma vez que a maior inconveniência percebida dentro das empresas é a falta de congruência entre os valores partilhados pelos membros e os valores contidos no papel, como destacam Tamayo et al. (2000, p. 292).

A partir do momento que se identificam as maiores dualidades entre as percepções dos funcionários da empresa acerca da cultura organizacional, podemse traçar caminhos que reduzam esta divergência e gerem melhor performance para a organização.

\subsection{Formulação do problema}

Partindo do princípio que cultura organizacional é um tema importante para muitas empresas, principalmente para empresas de grande porte, pois faz com que elas se diferenciem umas das outras, podendo contribuir para o alcance de vantagem competitiva no mercado no qual estão inseridas, surgiu o interesse pelo o tema em questão. Procurou-se então, uma empresa de grande porte que fosse avaliada por seus executivos e concorrentes como tendo uma cultura forte. A 
finalidade dessa procura foi analisar se a cultura era percebida por todos os funcionários da mesma maneira como fora pensada inicialmente. Ao conhecer a empresa e observar a realidade das áreas, percebeu-se que funcionários da área fim passavam maior parte do seu horário de trabalho em contato direto com o mercado e eles eram, em grande parte, responsáveis por mostrar e divulgar a cultura da organização para clientes, consumidores, concorrentes e sociedade de modo geral. Ao contrário da área fim, as áreas de suporte passavam todo o seu tempo trabalhando internamente. A partir dessa situação e não encontrando estudos comparativos de cultura organizacional de empresas com realidade semelhante ao da pesquisada, surgiu o questionamento: será que a área fim da empresa percebe a cultura da organização da mesma forma que as áreas de suporte, que realizam suas atividades internamente na organização?

\subsection{Objetivo geral}

Comparar a percepção de cultura organizacional entre profissionais da área fim e de suporte de uma empresa de grande porte.

\subsection{Objetivos específicos}

- Analisar fatores que compõem a cultura para diferentes autores;

- Caracterizar a área fim da empresa e suas áreas de suporte;

- Analisar os pontos relevantes da cultura da empresa que são divulgados por meio da internet;

- Caracterizar os fatores que compõem a cultura organizacional nas áreas fim e meio da organização objeto de estudo.

\subsection{Justificativa}

Cultura organizacional é um tema relevante para muitas empresas, principalmente para as de grande porte, pois em muitos casos mantêm relação direta com o alcance da vantagem competitiva. Essa relação da cultura com a estratégia da empresa é abordada por Barney (1986). Ele a relaciona com o 
desempenho financeiro superior da organização. E para que a cultura contribua com esse desempenho, é necessário satisfazer três pontos: a cultura deve criar valor econômico, precisa ser rara e ser de difícil imitação. Sendo assim, a cultura é definida para Barney (1986) como um componente da vantagem competitiva da empresa. Organizações que tenham cultura forte e esses três pontos satisfeitos, são capazes de ter melhores resultados que as concorrentes.

Ao estudar uma organização deve-se considerar o ambiente interno e externo nos quais ela está inserida. Essa interação influencia tanto a organização quanto o ambiente. Assim, todos os funcionários de uma organização "contribuem para esse intercâmbio constante, sendo seus valores componentes para a formação da cultura da organização" (PIRES; MACÊDO, 2006, p.87).

As organizações também, segundo Silva e Zanelli (2004, p.413), produzem artefatos e elementos culturais, como rituais, lendas, entre outros que dão regularidade e previsibilidade às relações dos funcionários com a empresa e fazem que eles se adaptem ao ambiente. Então, "a cultura é compreendida como um instrumento que regula e adapta pessoas e organizações" (SILVA; ZANELLI, 2004, p.413).

"O estudo da cultura é importante por ser determinante no desempenho individual, no desempenho no trabalho e na produtividade da empresa" (TAMAYO et al., 2000, p. 290) e pode ser entendida como uma percepção comum mantida pelos membros da organização. Assim, espera-se que "indivíduos com diferentes históricos e em níveis diversos da organização descrevam a cultura organizacional em termos semelhantes" (ROBBINS, 2005, p.376).

Contudo, nem sempre a cultura é percebida por todos na organização da mesma maneira. Tamayo et al. (2000, p. 292) argumentam que "o maior inconveniente [...] é a falta de congruência entre os valores estabelecidos no papel e os realmente partilhados pelos membros".

Se ela não está disseminada em todos os níveis hierárquicos, os funcionários não correspondem às expectativas por não saberem como devem agir ou o que deles é esperado. Então o que fazer nesse caso? Os líderes das organizações são responsáveis por moldá-la e disseminá-la por meio das práticas diárias da organização e, além disso, os funcionários precisam conhecer e partilhar os valores culturais (HOFSTEDE, 1998 apud FERREIRA; ASSMAR, 2008). 
Além disso, Silva e Zanelli (2004, p.413) acrescentam que se os líderes das organizações compreendessem o comportamento, as expectativas, os pensamentos e os sentimentos dos funcionários, poderiam utilizar melhores técnicas para o controle e para o aumento da produtividade.

Também não foram encontrados estudos que abordassem a relação entre cultura organizacional e a percepção de funcionários de diversas áreas da empresa que exercem atividades tanto no meio externo, quanto interno à empresa. Percebese então a relevância do presente trabalho, a fim de identificar os principais pontos de diferenciação, buscando maneiras de atingir todos os níveis e todas as áreas de forma eficiente, garantindo a disseminação da cultura.

\subsection{Métodos e técnicas de pesquisa}

Para identificar as diferenças de percepção da cultura organizacional entre a área de Vendas e as áreas que dão suporte a ela, foi necessário, primeiramente, revisar os principais conceitos de cultura organizacional e analisar os fatores que a compõem do ponto de vista de diferentes autores. Logo após, foi preciso entender a realidade das áreas da organização pesquisada, tanto a área de Vendas quanto às áreas que dão suporte a ela, como: Recursos Humanos, Marketing, Administrativo Financeiro e Logística, a partir da análise de documentos internos da organização. Para identificar a percepção dos funcionários de diferentes áreas, foi realizado levantamento de dados (survey) a partir da aplicação de um instrumento construído e validado por Ferreira et al. (2002). Assim, foi possível, por meio do uso do questionário, coletar os dados sobre a percepção dos funcionários em relação à cultura da empresa. Os resultados encontrados foram comparados entre a área de Vendas e as outras áreas, e com essa comparação foi possível perceber as diferenças entre a cultura das áreas. A análise foi realizada também com base nos pontos relevantes da cultura divulgados pela empresa através da internet.

\subsection{Estrutura e organização do trabalho}

No referencial teórico será estudada a origem sobre a cultura organizacional e, em seguida, serão revisados e comparados conceitos e definições de diversos autores a respeito do tema. Diferentes abordagens de cultura organizacional serão 
analisadas, assim como os fatores que compõem a cultura e aspectos que devem ser levados em consideração para definir a cultura de uma organização segundo vários autores.

Após a análise da produção nacional sobre o tema, será apresentada a metodologia empregada no estudo objetivando identificar possíveis diferenças de percepção da cultura organizacional entre as diferentes áreas da empresa.

Em seguida, serão apresentados e analisados os resultados da pesquisa.

E, por fim, serão expostas considerações importantes a respeito do estudo realizado, além de apresentar as referências das obras citadas nesse trabalho e o anexo com o questionário utilizado. 


\section{REFERENCIAL TEÓRICO}

\subsection{Conceitos e definições de cultura organizacional}

Segundo Ferreira e Assmar (2008, p.125) os estudos sobre cultura organizacional começaram nos anos de 1980 com o grande desempenho das empresas japonesas e com a crença de que o principal fator para o sucesso das organizações era o envolvimento dos funcionários com os valores e filosofia das mesmas. A partir disso, muitos estudos começaram a ser realizados para verificar as reais implicações da cultura para as organizações.

Outros autores também explicam o porquê da origem dos estudos sobre cultura organizacional, assim como Candido e Junqueira (2003, p.9) que explicam que o conceito de cultura corporativa e de cultura organizacional surgiram após a Segunda Guerra Mundial, no final da década de 70 e durante 1980, para responder às questões sociológicas emergentes até então não respondidas pelas organizações.

Segundo Morgan (1996, p.115) a palavra cultura, antigamente, se restringia à ideia de cultivo, processo de desenvolver a terra, agricultura. Mais tarde passou-se a utilizar também a palavra refletindo ideologia, valores, leis e rituais de sistemas sociais de conhecimento. "Ambos os usos derivam das observações do século XIX a respeito das sociedades 'primitivas' ao transmitir a ideia de que diferentes sociedades manifestam diferentes níveis e padrões de desenvolvimento social."

"A inquietação com a necessidade de compreender as diferenças dos comportamentos de grupos e entre nações foi progressivamente conferindo outro sentido à palavra cultura" (SILVA; ZANELLI, 2004, p.407). Esse outro significado dado à palavra cultura é hoje utilizado no contexto das organizações.

Para Pires e Macêdo (2006, p.84) em um ambiente dinâmico e globalizado como os das empresas atuais, "onde as interações sociais ocorrem entre pessoas de diferentes regiões e países, a palavra cultura emerge como uma das variáveis fundamentais para a compreensão do fenômeno organizacional" e por isso passa a ser um tema relevante a ser estudado. 
Como citado por Moorhead (2007), um curioso aspecto da cultura organizacional é que seu conceito não possui uma única definição, dessa forma, cada autor desenvolve sua própria definição, que varia da mais específica a mais ampla.

Cândido e Junqueira (2003) destacam a dificuldade de compreender a cultura organizacional por ela ter caráter intangível e assim não há um consenso teórico sobre ela. Quando os autores citam o caráter intangível da cultura, se referem à subjetividade, à simbologia e ao significado da organização. Com isso são estabelecidos valores e comportamento, ou seja, pressupostos que devem ser seguidos por todos e que foram desenvolvidos ao longo do tempo pela interação entre as pessoas, entre as pessoas e a organização e entre a organização e seu ambiente.

Assim como Cândido e Junqueira, Schein (1986, p. 47 apud FLEURY, 1989, p.20) também aborda a interação existente na organização que desenvolve pressupostos básicos, a saber: "cultura organizacional é o conjunto de pressupostos básicos que um grupo inventou, descobriu ou desenvolveu ao aprender como lidar com os problemas de adaptação externa e integração interna". Ele acredita que esses pressupostos "funcionaram bem o suficiente para serem considerados válidos e ensinados a novos membros como a forma correta de perceber, pensar e sentir, em relação a esses problemas". Dessa forma, a cultura refletirá o que o grupo aprendeu ao resolver problemas ao longo de sua história e tendo sucesso, os valores serão repetidos, reforçando a cultura.

Torquato (1991, p.3) define cultura como o "somatório dos inputs técnicos, administrativos, políticos, estratégicos, táticos, misturados às cargas psicossociais, que justapõe fatores humanos individuais, relacionamentos grupais, interpessoais e informais". Dessa maneira, é impossível definir uma cultura apenas a partir de sua estrutura formal, é necessário ainda levar-se em consideração todos seus aspectos informais.

Torquato (1991, p.5) destaca a necessidade da identificação da cultura interna, para que as decisões a respeito das diretrizes administrativas estejam embasadas no conhecimento dos problemas que afetam a comunidade e assim possam transpor dificuldades. Daí, a necessidade de se identificar as diferentes visões que se possa ter sobre uma mesma cultura, a fim de alinhá-las. 
Para Pires e Macêdo (2006, p.83) "a cultura é um dos pontos-chave na compreensão das ações humanas", pois cada grupo age, sente, pensa e tem maneiras de percepção características de seu grupo. Dessa forma, há um padrão coletivo onde existem regras, hábitos e artefatos. Porém, mais do que isso, eles acreditam que a "cultura significa construção de significados partilhados pelo conjunto de pessoas pertencentes a um mesmo grupo social". Os autores também destacam que "a cultura implica estabilidade, enfatiza demonstrações conceituais, serve como fator aglutinador para levar os membros do grupo em direção ao consenso". Todos esses pressupostos levam a um padrão coletivo, como citado anteriormente.

Segundo Pires e Macêdo (2006, p.83-84), a cultura possibilita que um grupo se fortaleça ou se desintegre, pois para uma pessoa possuir a cultura de um grupo, primeiro ela precisa se adaptar à realidade do grupo no qual está inserido. Portanto, a cultura expressa valores e crenças de um grupo. "Tais valores manifestam-se por meio de símbolos, como mitos, rituais, histórias, lendas e uma linguagem especializada, orientando os indivíduos de uma referida cultura na forma de pensar, agir e tomar decisões".

"O indivíduo é essencialmente um ser de cultura. Nesse sentido, a cultura torna possível a transformação da natureza e faz com que os povos se diferenciem pelas suas elaborações culturais, invenções e diferentes resoluções e encaminhamentos dos problemas" (PIRES; MACÊDO, 2006, p.84). A partir dessa citação, é possível perceber que ao mesmo tempo em que a cultura unifica certo grupo de pessoas ou organização, ela também faz com que o grupo ou a organização se diferenciem dos demais, pois cada um tem seus valores, suas formas de agir e de tomar decisões.

Ainda para Pires e Macêdo (2006) a cultura é um conjunto complexo e multidimensional cujos componentes são compartilhados e transmitidos pelos membros de um dado grupo.

Quanto ao compartilhamento da cultura, Torres (2008, p.183) acredita que quanto maior o grau de partilha entre os trabalhadores da organização, mais forte e consensual será a cultura. Ele também explica o que representa o padrão de conformidade ideal da cultura para organização: "reduz-se a um conjunto de símbolos, crenças, valores, mitos e outros factores pertencentes à ordem do 
simbólico, que representam o padrão da conformidade ideal e que, por isso, se deseja interiorizar (ou inculcar) prioritariamente a todos os atores da organização".

\subsection{Diferentes abordagens de cultura organizacional}

Assim como há uma diversidade de conceitos relacionados à cultura organizacional, muitos autores também possuem diferentes visões quanto aos níveis da cultura organizacional ou quanto aos fatores culturais existentes.

De acordo com Torquato (1991, p.4), existem quatro principais tipos reforçadores de culturas organizacionais, são eles: o aspecto histórico, a natureza técnica da empresa, seu modelo de gestão e o chamado "osmose geográfica".

O primeiro, para Torquato (1991, p.4), é relacionado aos anos de experiência que a empresa possui, os velhos costumes que são conservados devido aos anos e a solidez difícil de ser modificada por elementos do presente. O segundo aspecto, relacionado à natureza técnica da empresa: "geralmente algumas organizações são influenciadas devido a sua atividade fim, por exemplo, o setor metalúrgico conta com intensa atividade de sindicatos, e propicia grande rede informal".

No aspecto modelo de gestão da organização, consideram-se fatores como autocracia, democracia etc. Cada um desses fatores traduz um tipo de cultura diferente. Por último, a osmose geográfica, que significa os aspectos da região onde a organização se encontra e que são naturalmente influenciadores de sua cultura. "As organizações de uma mesma região, geralmente tendem a se comportar de forma similar" (TORQUATO, 1991, p.4).

Já Robbins (2005) sugere sete características básicas da essência da cultura de uma organização. São elas: inovação e assunção de riscos; atenção aos detalhes; orientação para os resultados; orientação para as pessoas; orientação para a equipe; agressividade; estabilidade.

Para Katz e Kahn (1978 apud TAMAYO, 2000, p.291) a cultura apresenta três componentes que orientam o funcionamento da empresa, são eles: os papéis, as normas e os valores. Os autores definem papéis como formas de comportamento que o funcionário deve ter ao realizar certas tarefas, assim diferenciam funções e cargos na empresa. "As normas são expectativas transformadas em exigências" e os valores são ideologias da empresa de forma generalizada. Esses dois últimos são fatores integradores, ou seja, que toda organização compartilha. 
Tamayo et al. (2000) utilizam uma medida chamada de Inventário de Valores Organizacionais para avaliar os valores de uma organização em três dimensões bipolares. São elas: autonomia versus conservadorismo, hierarquia versus igualitarismo e domínio versus harmonia. A primeira diz respeito à relação do indivíduo com a organização (coletivo) em que os interesses são diferentes. Já a segunda refere-se à estrutura da empresa. É fato que ela é fundamental para o funcionamento da organização, pois define as funções e as relações existentes. Porém, a partir dela é criada a ideia de hierarquia e com isso, autoridade. Algumas organizações utilizam essa abordagem. Outras preferem uma estrutura igualitária, o que implica em poucos níveis de autoridade e gestão participativa. Alguns exemplos de valores culturais típicos de estrutura igualitária citados por Tamayo (2000, p. 301) são: justiça social, igualdade, responsabilidade e equidade. A terceira e última, é a relação que certa organização tem com seus concorrentes. No pólo domínio, os valores encontrados se relacionam diretamente com os esforços para obter controle do mercado. No pólo harmonia, os valores predominantes são cooperação e integração com o ambiente.

Já Schein (1986 apud FLEURY, 1989, p.20) acredita que a cultura pode ser entendida como tendo vários níveis: "nível dos artefatos visíveis, nível dos valores que governam o comportamento das pessoas e nível dos pressupostos inconscientes".

O primeiro nível, para Schein (1986 apud FLEURY, 1989), refere-se ao ambiente da organização, arquitetura, layout, padrões de comportamento, maneira dos funcionários se vestirem, entre outros. Ou seja, rituais, símbolos, estrutura e processos da organização. Segundo Schein, esse é o nível mais fácil de observar, porém é o mais difícil para se compreender a lógica do comportamento do grupo por ser superficial.

Não é fácil observar diretamente o segundo nível, por isso, para identificá-lo é necessário entrevistar membros da organização ou analisar documentos formais da mesma. São os valores compartilhados pelos membros ou pelo menos o que eles acham como sendo razão para se comportarem de tal forma. Porém, muitas vezes essa razão se confunde com idealizações do que a organização espera de seus funcionários (SCHEIN, 1986 apud FLEURY, 1989). Além das maneiras que o autor cita como possíveis para identificação do segundo nível, há também o survey que poderia ser utilizado para alcançar o mesmo objetivo. 
É no terceiro nível que as razões do comportamento dos membros da organização são especificadas. Schein (1986 apud FLEURY, 1989) considera que são as crenças, percepções e sentimentos inconscientes, ou seja, como as pessoas percebem, pensam e sentem. Quanto mais os valores são compartilhados por todos, mais os comportamentos são direcionados para o que a organização entende como cultura e assim, esses pressupostos vão se tornando cada vez mais inconscientes e mais enraizados.

Pires e Macedo (2006, p. 91) criticam a abordagem de Schein (1985 apud PIRES; MACÊDO, 2006), pois destacam que "a definição de Schein é considerada de certo modo limitada na medida em que não considera o contexto global no qual o grupo ou a organização em questão está inserida".

Hofstede (1994, p.180 apud PIRES; MACÊDO, 2006, p. 91) considera, além dos aspectos internos da organização, o contexto global e a influência de todo o ambiente na formação da cultura. Para ele, "não se pode tornar inteligível a dinâmica humana nas organizações sem conhecer a cultura e a sociedade na qual ela se insere".

Pires e Macêdo (2006, p. 91) comparam ainda a abordagem de Schein com a de Hofstede, que será citada posteriormente, e observam que Schein (1985, p.247 apud PIRES; MACÊDO, 2006) "enfatiza a cultura organizacional como o resultado da dinâmica de uma determinada organização e [...] Hofstede, que considera a cultura organizacional como o resultado de uma dinâmica cultural maior da sociedade na qual esta organização se insere".

A relação entre a cultura organizacional e a nacional foi estabelecida a partir de estudos que Hofstede (1980 apud SILVA; ZANELLI, 2004) realizou em vários países entre 1968 e 1972 com 72 escritórios diferentes da IBM, aplicando 116 mil questionários. Os resultados da pesquisa mostraram quatro dimensões da cultura nacional e, mais tarde, através de outros estudos, Hofstede identificou a quinta dimensão. São elas: distância do poder, evitar incertezas, individualismo versus coletivismo, masculinidade versus feminilidade e orientação de curto prazo versus orientação de longo prazo.

Distância do poder refere-se a como o poder é distribuído nas organizações. Hofstede (1980 apud SILVA; ZANELLI, 2004, p.421-422) acredita que é possível perceber como o poder é distribuído analisando as relações formais de hierarquia: "A distância de poder entre um gerente e um funcionário pode ser compreendida 
como a diferença entre o limite no qual o gerente pode determinar o comportamento do funcionário e o limite no qual o funcionário pode determinar o comportamento do gerente".

A dimensão "evitar incertezas" refere-se ao nível de aceitação das pessoas para situações incertas. Hofstede (1980 apud SILVA; ZANELLI, 2004, p.422) explica que por isso são utilizadas tecnologias e são criadas leis que regulamentam 0 comportamento das pessoas. "Um país com baixo índice de enfrentamento de incertezas, a tendência é a de que a dificuldade seja menor para conviver com esse tipo de situação [...] nas organizações, a tendência é a de que os papéis e as regras não sejam detalhadas e a obediência não seja rígida".

$\mathrm{Na}$ dimensão individualismo versus coletivismo a principal questão é se a natureza humana é boa ou má, se for boa, as pessoas tendem a confiar mais nas outras, e se for má, pressupõe-se que as pessoas são mais egocêntricas. "Quanto maior o grau de confiança entre as pessoas em uma sociedade, menor é o grau de controle necessário nas organizações", de acordo com Hofstede (1980 apud SILVA; ZANELLI, 2004, p.421).

Quanto à dimensão masculinidade versus feminilidade, Hofstede (1980 apud SILVA; ZANELLI, 2004) destaca que dependendo do gênero, há comportamentos associados a cada papel. Dessa forma, o objetivo dessa categoria é avaliar os valores sociais dominantes para cada sexo: assertividade, dinheiro e bens materiais ou bem-estar das pessoas.

A última dimensão, orientação de curto prazo versus orientação de longo prazo, refere-se ao conceito de tempo e a partir dele podem ser estabelecidas prioridades e metas. A ênfase pode ser no passado, presente ou futuro. O exemplo dado é que culturas que dão maior importância ao futuro valorizam o planejamento de longo prazo em suas organizações (HOFSTEDE, 1980 apud SILVA; ZANELLI, 2004).

A partir de novos estudos, Hofstede et al. (1990 apud FERREIRA; ASSMAR, 2008, p. 127-128) "desenvolveram um questionário com a finalidade de identificar os valores e as práticas que caracterizam a cultura organizacional". Para os valores foram identificadas as seguintes dimensões: necessidade de segurança, centralidade do trabalho e necessidade de autoridade. Já para as práticas, as dimensões foram: orientação para processos versus resultados, orientação para empregado versus tarefa, orientação paroquial versus profissional, sistema aberto 
versus fechado, sistema rígido versus flexível e orientação normativa versus pragmática. O questionário foi aplicado em vinte organizações diferentes de dois países e os resultados que Hofstede e equipe chegaram foram que essas organizações se diferenciavam em relação à maioria das práticas, porém os valores continuavam os mesmos ou tinham pouca alteração. Além disso, foi possível perceber que as práticas se relacionam diretamente com a estrutura da organização, com as tarefas e com o sistema de controle.

Como explicado anteriormente, Hofstede et al. (1990 apud FERREIRA; ASSMAR, 2008, p. 127) entendem que a cultura organizacional se manifesta através de práticas e de valores. Os dois se contrapõem, pois os valores "só se modificam segundo sua própria lógica" e as práticas podem mudar caso seja planejada essa mudança. As práticas incluem os rituais, que são formados pelas atividades coletivas; os heróis, pessoas que são modelo de comportamento para os demais membros de uma organização; e os símbolos, que podem ser palavras, gestos e/ou objetos com significado especial. Já os valores são "representados por sentimentos inconscientes e indiscutíveis, que não podem ser diretamente observados".

De acordo com as ideias de Hofstede (1998 apud FERREIRA; ASSMAR, 2008, p. 127) os fundadores e/ou líderes da organização são responsáveis por moldar a cultura, porém nem sempre seus membros compartilham os valores. Hofstede destaca que os funcionários não precisam compartilhá-los, no entanto, eles precisam, necessariamente, adotar as práticas da organização se quiserem trabalhar nela. Assim, "é por meio das práticas diárias, transmitidas aos membros mediante mecanismos de socialização, que essa cultura afeta seus membros".

Hofstede (1997 apud FERREIRA; ASSMAR, 2008) entende que as práticas são a essência da cultura de uma organização, ou seja, as práticas operacionalizam a cultura, é por meio delas que a cultura é disseminada. Já no caso dos valores, eles operacionalizam a cultura nacional.

Morgan (1996, p.136) destaca que a "estrutura organizacional, regras, políticas, objetivos, missões, descrições de cargos e procedimentos operacionais padronizados" são referências para os funcionários dando sentido para o trabalho das pessoas e podem ser considerados também como artefatos culturais e, portanto, também caracterizam a realidade da organização.

Morgan (1996, p.137) ainda salienta que "valores tribais da sociedade, crenças e tradições podem estar baseados em parentesco ou outras estruturas 
sociais, muitos aspectos de uma cultura organizacional estão, portanto, baseados em aspectos rotineiros das práticas diárias".

Além da cultura da organização, existem as subculturas, que são culturas diferentes para cada unidade da organização. Schein (1986 apud FLEURY, 1989, p.20) observa que freqüentemente "os grupos com background ocupacional semelhante tendem a desenvolver culturas próprias no interior das organizações". Assim, dentro de uma empresa, além da cultura corporativa, pode existir, por exemplo, a cultura da área da Logística, a cultura da área Comercial e assim por diante.

Schein (1986 apud FLEURY, 1989) atribui aos fundadores da organização a responsabilidade de moldar os padrões culturais da mesma. Os líderes apresentam valores pessoais e ao mesmo tempo sabem o papel que a organização deve desempenhar, com isso vão passando a cultura organizacional para os outros membros da organização.

Com isso e de acordo com Ferreira et al.(2002) percebe-se a importância do tema para as empresas. É interessante investigar o impacto dos valores e práticas colocados em ação pela organização segundo a percepção de seus membros, sejam em relação a suas atitudes no trabalho, comportamento, sua eficiência ou sua eficácia. 


\section{MÉTODOS E TÉCNICAS DE PESQUISA}

\subsection{Delineamento da pesquisa}

O tema principal da pesquisa é a cultura organizacional. O estudo foi realizado em uma empresa de grande porte, onde a cultura organizacional é considerada forte pela administração central e por seus concorrentes. Porém, não se sabe se a percepção dessa cultura é uma só por todas as áreas da empresa ou se há diferença, principalmente pelo fato de a maioria dos funcionários da área de Vendas passarem grande parte do dia no meio externo, ou seja, atendendo clientes.

Levando em consideração os pontos levantados acima, a pesquisa teve caráter misto, sendo parte do trabalho qualitativo e parte, quantitativo. Quanto à pesquisa qualitativa, foi utilizada a pesquisa documental por meio de informações contidas no site da empresa em relação à cultura organizacional. Em relação à pesquisa quantitativa, na coleta de dados foi utilizada a técnica de levantamento de dados, survey, por meio de um questionário que será detalhado adiante.

Quanto aos fins, a pesquisa foi descritiva por "estabelecer correlações entre variáveis e definir sua natureza. Não tem compromisso de explicar os fenômenos que descreve, embora sirva de base para tal explicação." (VERGARA, 2005, p. 47).

Em relação aos meios, a pesquisa se caracterizou por ser uma pesquisa de campo uma vez que foi realizada investigação empírica no local onde ocorre o fenômeno (VERGARA, 2005).

A variável dependente do estudo foi a percepção de cultura organizacional de cada área e as variáveis independentes foram as áreas da empresa como Vendas, Recursos Humanos, Logística, Administrativo Financeiro e Marketing. A caracterização das variáveis foi realizada ao detalhar e ao descrever as características da amostra.

\subsection{Caracterização da organização}

A empresa pesquisada é de grande porte, atua no setor de bebidas, está no mercado há nove anos e é bastante conhecida pela sociedade. Por estar presente 
em grade parte do Brasil, possui várias fábricas e centros de distribuições. Sua cultura é considerada forte pelos concorrentes e pela própria Administração Central e seus produtos são reconhecidos pelo mercado por sua qualidade. A pesquisa foi aplicada no centro de distribuição do Distrito Federal, responsável por atender Brasília e seu entorno. O centro de distribuição conta com 200 funcionários divididos em cinco áreas: Vendas, Recursos Humanos, Administrativo Financeiro, Logística e Marketing. A área de Vendas é sua área fim e todas as outras são definidas como de suporte.

É preciso ressaltar que não foram descritos maiores detalhes para que não fosse identificada a empresa. E, além disso, é importante enfatizar que durante todo o estudo, a empresa será denominada por apenas "empresa" para que seja mantido o sigilo de seu nome, conforme acordado com seus dirigentes.

\subsection{População e amostra}

O universo de estudo caracterizou-se por uma população de 200 funcionários de um centro de distribuição da referida empresa situada no Distrito Federal. A população em questão é dividida na área fim e em suas áreas de suporte, além de possuírem os seguintes cargos: analista, auxiliar, conferente, coordenador, gerente, supervisor, técnico, vendedor.

A área fim da empresa é a área de Vendas com 130 funcionários e com as funções de vendedores, supervisores e gerentes. Durante grande parte do dia, a maior parte dos funcionários dessa área não trabalha internamente na empresa, pois visita os clientes em seus pontos de venda.

As áreas de suporte contem 70 funcionários e inclui: Marketing, Recursos Humanos, Logística e Administrativo Financeiro. A área de Marketing possui auxiliares, supervisores e gerente. A área de Recursos Humanos possui técnicos, analistas e gerente. $\mathrm{Na}$ área de Logística trabalham conferentes, técnicos, analistas, supervisores, coordenadores e gerente. E, por fim, o Administrativo Financeiro possui técnicos, analistas, supervisor e coordenador. Todos os funcionários dessas áreas passam o dia na própria empresa, sem contato com o meio externo durante o horário de trabalho. 
Os cargos de vendedor, auxiliar, conferente e técnico somam 155 pessoas e têm profissionais com formação completa no Ensino Médio e podem estar cursando o Ensino Superior.

Para os cargos de analista, supervisor e coordenador, todos devem possuir Ensino Superior completo. Esses cargos somam 36 funcionários.

Há seis gerentes na Empresa pesquisada e alguns requisitos para esse cargo são ensino superior completo e mais de três anos na empresa tendo assumido outros cargos anteriormente.

A amostra foi composta por 97 funcionários da área de vendas e 61 funcionários das outras áreas para que se mantivesse 0 índice de 0,05 de confiabilidade.

Para seleção dessas pessoas nas diversas áreas e níveis, foi utilizada amostra aleatória simples, em que "cada elemento da população tem uma chance determinada de ser selecionado. Em geral, atribui-se a cada elemento da população um número e depois se faz a seleção aleatoriamente, casualmente" (VERGARA, 2005, p.50).

\subsection{Caracterização do instrumento de pesquisa}

Foi utilizada a versão reduzida do Instrumento Brasileiro para Avaliação da Cultura Organizacional (IBACO) de autoria de Ferreira et al. (2002). O questionário é uma avaliação da cultura organizacional por meio de valores e práticas, conforme a opção teórica escolhida e foi validado cientificamente pelos autores e a sua versão reduzida apresenta igual validade científica.

O instrumento original é composto por 94 afirmativas. A versão reduzida contém 30 afirmativas distribuídas igualmente entre os fatores associados a valores e práticas. Dentre os fatores relacionados a valores, têm-se profissionalismo cooperativo, profissionalismo competitivo e individualista e a satisfação e bem-estar dos empregados. Nos fatores relacionados a práticas têm-se a integração externa, a recompensa e treinamento e a promoção do relacionamento interpessoal, conforme quadro a seguir: 


\begin{tabular}{|c|c|c|}
\hline \multicolumn{3}{|c|}{ FATORES } \\
\hline VALORES & Explicação & Itens \\
\hline Profissionalismo cooperativo & $\begin{array}{l}\text { Relacionado à valorização dos empregados que } \\
\text { executam suas tarefas com eficácia e competência, } \\
\text { demonstrando espírito de colaboração, habilidade, } \\
\text { dedicação, profissionalismo e capacidade de iniciativa, } \\
\text { contribuindo, desse modo, para o alcance das metas } \\
\text { comuns da organização. }\end{array}$ & $14,17,19,21$ e 22 \\
\hline $\begin{array}{l}\text { Profissionalismo competitivo } \\
\text { e individualista }\end{array}$ & $\begin{array}{l}\text { Relacionado à valorização prioritária da competência, } \\
\text { do desempenho, e da eficácia individuais na execução } \\
\text { de tarefas para obtenção dos objetivos desejados, } \\
\text { ainda que isso implique a necessidade de "passar por } \\
\text { cima" dos colegas. }\end{array}$ & $23,24,25,29$ e 30 \\
\hline $\begin{array}{l}\text { Satisfação e bem-estar dos } \\
\text { empregados }\end{array}$ & $\begin{array}{l}\text { Relacionado à valorização do bem-estar, da satisfação, } \\
\text { e da motivação dos empregados, isto é, à humanização } \\
\text { do local de trabalho, de modo a torná-lo agradável e } \\
\text { prazeroso. }\end{array}$ & $3,6,10,12,18$ \\
\hline PRÁTICAS & Explicação & Itens \\
\hline Integração externa & $\begin{array}{l}\text { Relacionado a práticas voltadas para o planejamento } \\
\text { estratégico, a tomada de decisão e o atendimento ao } \\
\text { cliente externo, com foco, portanto, nos escalões } \\
\text { superiores da organização. }\end{array}$ & $2,4,7,8$ e 15 \\
\hline Recompensa e treinamento & $\begin{array}{l}\text { Relacionado a práticas vinculadas aos clientes internos } \\
\text { e aos sistema de recompensas e treinamento adotados } \\
\text { pela empresa. }\end{array}$ & $5,11,16,26$ e 28 \\
\hline $\begin{array}{l}\text { Promoção do relacionamento } \\
\text { interpessoal }\end{array}$ & $\begin{array}{l}\text { Relacionado a práticas orientadas para promoção das } \\
\text { relações interpessoais e satisfação dos empregados, } \\
\text { favorecendo, assim, a coesão interna. }\end{array}$ & $1,9,13,20$ e 27 \\
\hline
\end{tabular}

Quadro 1 - Estratificação Fatorial do IBACO

Fonte: Ferreira et al. (2002, p. 275-279), com adaptações.

A primeira parte do questionário foi composta pelas instruções de preenchimento da pesquisa e explicação do objetivo. A segunda parte inclui itens que representavam os fatores que podem expressar o dia-a-dia da empresa e foram respondidos a partir da escala de 1 a 5, sendo: 1 "não se aplica de modo nenhum", 2 "pouco se aplica", 3 "aplica-se razoavelmente", 4 "aplica-se bastante" e 5 "aplica-se totalmente". A terceira parte abrangeu os dados demográficos, como: cargo atual, gênero, faixa etária, tempo na empresa, tempo no cargo atual e escolaridade.

\subsection{Procedimentos de coleta e de análise de dados}

O questionário foi aplicado no próprio local de trabalho durante o horário comercial. Não houve marcação de horário para a aplicação do mesmo. Ela foi individual com tempo para preenchimento livre. 
O pedido para participação na pesquisa foi feito pessoalmente aos funcionários de áreas de suporte a Vendas, informando-Ihes o caráter didático do estudo e seu objetivo, enfatizando que não seria necessário se identificar e que as informações coletadas seriam mantidas em sigilo.

Quanto à área de Vendas, o pedido de aplicação da pesquisa foi feito aos gerentes e aos supervisores que estavam trabalhando internamente nos dias de aplicação do questionário, pois eles mantêm contato diário com todos os funcionários. Esses solicitaram para aqueles que estiverem trabalhando externamente que preenchessem o questionário e entregassem à área de Recursos Humanos. Foi solicitado ainda que explicassem o caráter acadêmico da pesquisa e o sigilo das informações.

Todas as informações sobre a empresa foram retiradas da internet, local em que todos têm acesso, pois é proibida a utilização de informações extras por serem consideradas sigilosas.

As estatísticas utilizadas para análise dos dados do IBACO foram o desviopadrão e a média. Os dados foram tabulados no software Statistical Package for Social Sciences (SPSS), versão 17.0.

A média simples foi utilizada para o cálculo de cada fator que expressou 0 profissionalismo cooperativo, o profissionalismo competitivo e individualista, a satisfação e bem-estar dos empregados, a integração externa, a recompensa e treinamento e a promoção do relacionamento interpessoal. Com isso foi possível saber a percepção dos respondentes em relação a cada um dos fatores que caracterizam a cultura organizacional.

Segundo Ferreira et al. (2002), o grau de percepção de cada fator pode variar de 1 a 5, sendo que quanto maior o resultado, maior a percepção e a presença da prática na organização.

Sendo assim, valores entre 4 e 5 mostraram que o fator analisado era bastante ou totalmente percebido e presente no dia-a-dia dos funcionários. Valores entre 3 e 3,9 indicaram que o fator estava razoavelmente percebido e presente na vida profissional dos membros. Já resultados entre 2 e 2,9 mostraram que o fator pouco se aplicava ao cotidiano dos membros e era pouco percebido. E valores entre 1 e 1,9 indicaram que o fator não era percebido de modo algum pelos membros da organização. 
Foram utilizadas ainda as correlações de Pearson entre os fatores e as seguintes variáveis demográficas: cargo, área, gênero, faixa etária, tempo na empresa, tempo no cargo atual e escolaridade. 


\section{APRESENTAÇÃO E DISCUSSÃO DOS RESULTADOS DA PESQUISA}

Nesta seção, são apresentados os resultados obtidos através de informações no site da empresa e do questionário aplicado. A pesquisa documental descreve os pontos de cultura que a organização julga serem importantes e partilhados por todos os funcionários. As informações obtidas contribuem para análise dos resultados dos questionários.

Quanto ao questionário, primeiramente estão descritos os dados demográficos da amostra. Em seguida, são expostos os resultados dos fatores de cultura organizacional de acordo com a percepção dos participantes da pesquisa. Com isso é possível observar qual valor e qual prática são mais evidentes na organização estudada. Logo após essa etapa, são apresentados os resultados de cada fator individualmente e, para uma análise mais aprofundada, são evidenciados os resultados de cada item que compõem cada um desses fatores. Dessa forma, notam-se os itens que mais contribuíram para o resultado do fator em questão. Por fim, estão presentes as correlações existentes entre os dados demográficos e os fatores de cultura organizacional.

\subsection{Cultura organizacional para a empresa}

Para a empresa ${ }^{1}$, cultura organizacional é o modo da empresa como um todo fazer as coisas, é a combinação dos valores, crenças, práticas e princípios que orientam as ações e o comportamento dos funcionários. É a cultura que a diferencia das demais empresas de seu setor. A empresa acredita que a cultura atual é resultado da interação de todos os funcionários ao longo de sua existência e são eles os responsáveis pela sua manutenção e divulgação. A empresa também ressalta que os funcionários se orgulham de sua cultura e eles têm o compromisso de mantê-la. E a melhor forma de mantê-la é respeitando-a e praticando-a.

De acordo com a organização pesquisada, ela apresenta quatro valores

\footnotetext{
${ }^{1}$ Observa-se que, embora a organização tenha permitido a realização da pesquisa, não foi autorizada a sua identificação. Os dados a seguir foram extraídos do site da empresa, quando textuais foram colocadas aspas.
} 
principais. O primeiro valor mostra que os consumidores estão em primeiro lugar. Para empresa o contato permanente com os consumidores além de parceria com clientes e revendedores é essencial para que o público-alvo seja atendido com qualidade superior e esteja satisfeito com os produtos.

O segundo valor mostra a importância de se ter excelentes funcionários na empresa. Para empresa é imprescindível atrair, desenvolver e manter as melhores pessoas do mercado de trabalho. A empresa acredita que seus funcionários são um diferencial competitivo e para que tudo isso seja possível seu ambiente é informal e meritocrático. Além disso, a empresa, em seu discurso, destaca o crescimento profissional condizente com o desempenho, estimula a criatividade, reconhece e premia ótimos funcionários, valoriza o respeito e confiança. Ela também acredita que o erro honesto é uma oportunidade de aprendizado.

O terceiro valor é sonhar grande e para isso são definidas metas desafiadoras e os funcionários estão sempre focados em resultados. Esse foco leva à priorização do que é relevante para empresa e a um senso de urgência para realização das atividades. Os funcionários são vistos como donos, pois donos assumem as responsabilidades e querem o melhor para o seu negócio.

O quarto e último valor é a liderança. A empresa acredita que o exemplo pessoal do líder é muito importante para equipe e ele deve ser sempre ético em suas ações e ter paixão no que faz. Com isso, a empresa não tolera "malandragens e espertezas", pois a sua reputação tanto referente à qualidade de seus produtos, quanto à sua cultura ou imagem institucional não devem ser trocadas por resultados desonestos. Para liderar é necessário saber lidar com pessoas além de ter conhecimento de processos e do mercado.

A empresa possui seis competências que guiam suas ações. A primeira é o desafio em alcançar resultados extraordinários. Para isso os funcionários devem procurar atingir excelente desempenho e fazer a empresa crescer sem comprometer a qualidade e integridade da organização.

A segunda competência diz respeito ao conhecimento aprofundado do negócio da empresa. Os funcionários aplicam seus conhecimentos no dia-a-dia para gerar valor para os investidores e para sociedade.

Construção de relacionamentos fortes e boas equipes é a terceira competência. Essa competência e a maximização dos recursos utilizados e disponíveis são a base para o sucesso da empresa. 
A quarta competência é o atingimento de metas de forma simples, focado e disciplinado. Colocando em prática essa competência, as pessoas são recompensadas.

A quinta competência é similar a um dos valores da empresa, em que os funcionários pensam e agem como donos. Eles devem "demonstrar paixão e responsabilidade, tomando decisões e agindo em prol dos interesses de longo prazo" da empresa.

Por fim, a demonstração de liderança e o desenvolvimento das melhores pessoas formam a sexta competência. É preciso identificar e desenvolver os futuros líderes, além de preocupar-se com a sociedade e com a contribuição que cada um pode dar a ela. Para empresa é essencial "ter as pessoas certas, nos lugares certos, fazendo as coisas certas".

\subsection{Análise dos dados demográficos}

O questionário contém as seguintes variáveis demográficas: cargo, área, gênero, faixa etária, tempo na empresa, tempo no cargo atual e escolaridade.

Dos 53 respondentes, 50,9\% eram funcionários da área de vendas e 49,1\% funcionários das demais áreas suporte.

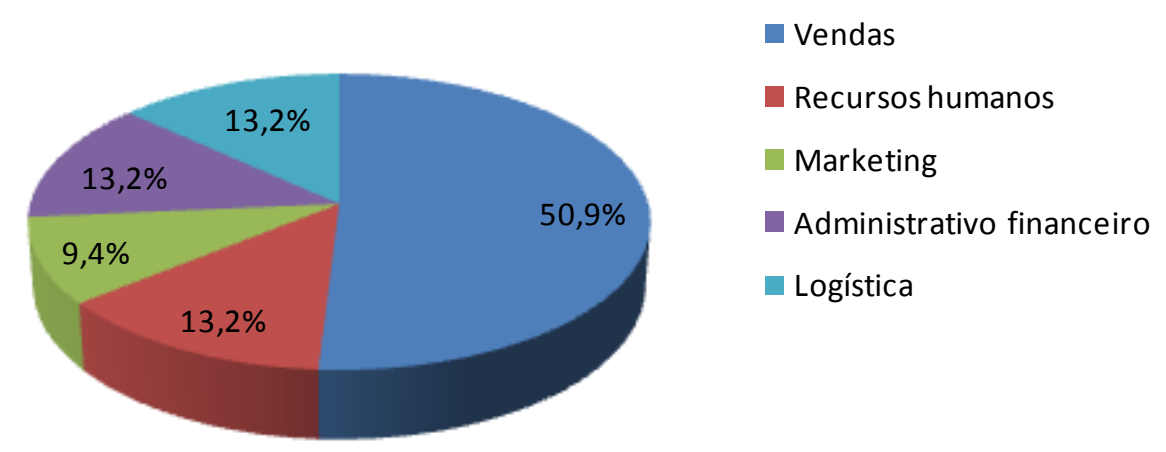

Gráfico 1 - Distribuição dos funcionários por área

$\mathrm{Na}$ área de vendas, 27 pessoas responderam o questionário, nas áreas de suporte às vendas, sete profissionais atuavam na área de Recursos Humanos, cinco 
na área de Marketing, sete do Administrativo Financeiro e sete da Logística de acordo com a Tabela 1.

Tabela 1 - Distribuição dos funcionários por área

\begin{tabular}{l|c|c}
\hline \multicolumn{3}{c}{ ÁREA ATUAL } \\
\hline \multicolumn{1}{c|}{ ÁREA ATUAL } & FREQUÊNCIA & PERCENTUAL \\
\hline Vendas & 27 & $50,9 \%$ \\
\hline Recursos humanos & 7 & $13,2 \%$ \\
\hline Marketing & 5 & $\mathbf{9 , 4 \%}$ \\
\hline Administrativo financeiro & 7 & $13,2 \%$ \\
\hline Logística & 7 & $13,2 \%$ \\
\hline \multicolumn{1}{c|}{ TOTAL } & 53 & $100,0 \%$ \\
\hline
\end{tabular}

Quanto ao cargo atual, $26,4 \%$ dos que responderam a pesquisa eram vendedores, 24,5\% eram supervisores, 18,9\% técnicos, 13,2\% analistas, 5,7\% gerentes, 3,8\% conferentes e 1,9\% coordenadores (vide Gráfico 2).

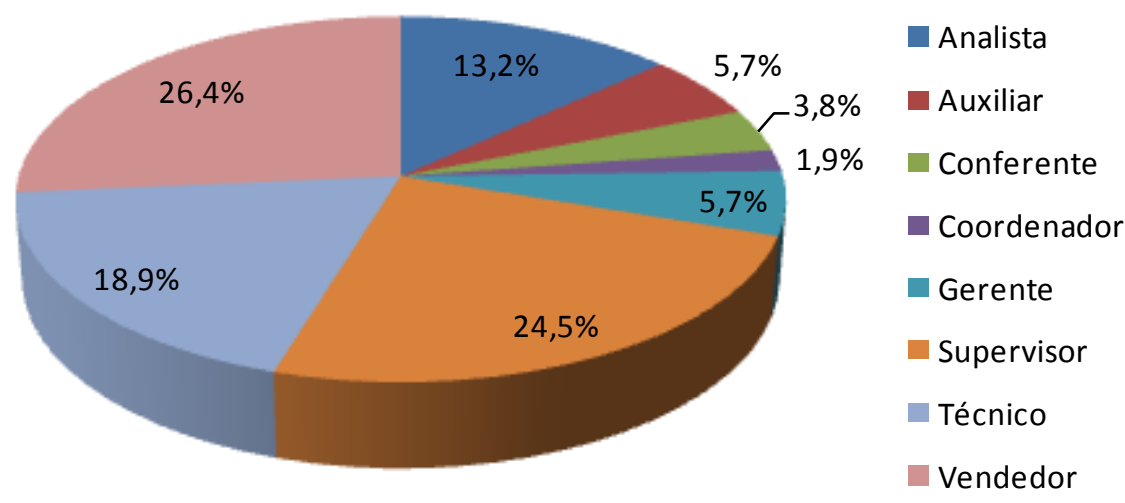

Gráfico 2 - Cargo atual

Pode-se notar, e levando em consideração as características da amostra, que aproximadamente $50 \%$ dos respondentes passam grande parte de seu dia fora da empresa. É possível chegar a essa conclusão por meio dos 14 vendedores e 13 supervisores responderam o questionário considerando que a área de vendas é a que possui maior número de supervisores. 
Dos 53 respondentes e de acordo com a Tabela 2, a maior parte são do sexo masculino com $73,6 \%$ correspondente a 39 homens e as demais respondentes são do sexo feminino totalizando $26,4 \%$, o que corresponde a 14 mulheres.

Tabela 2 - Gênero

\begin{tabular}{c|c|c}
\hline GÊNERO & FREQUÊNCIA & PERCENTUAL \\
\hline Masculino & 39 & $73,6 \%$ \\
\hline Feminino & 14 & $26,4 \%$ \\
\hline TOTAL & 53 & $100,0 \%$ \\
\hline
\end{tabular}

Quanto à faixa etária, a maior parte dos respondentes (77,6\%) tinha entre 20 a 30 anos e 22,6\% situavam-se na faixa dos 30 a 40 anos conforme Gráfico 3.

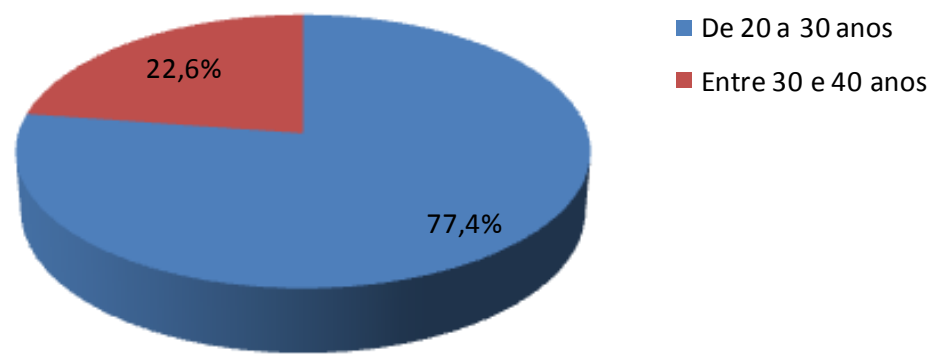

Gráfico 3 - Faixa Etária

A faixa etária de 20 a 30 anos é composta por 41 funcionários e a faixa entre 30 e 40 é composta por 12 pessoas. Não houve respondente abaixo dos 20 anos e acima de 40. Sendo assim, é possível concluir que a empresa é formada por pessoas mais jovens.

Conforme Gráfico 4, dos questionários respondidos, 47,2\% tinham entre 1 a 2 anos de empresa, 22,6 menos de 1 ano, e 15,1\% entre 2 a 4 anos e acima de 4 anos. 


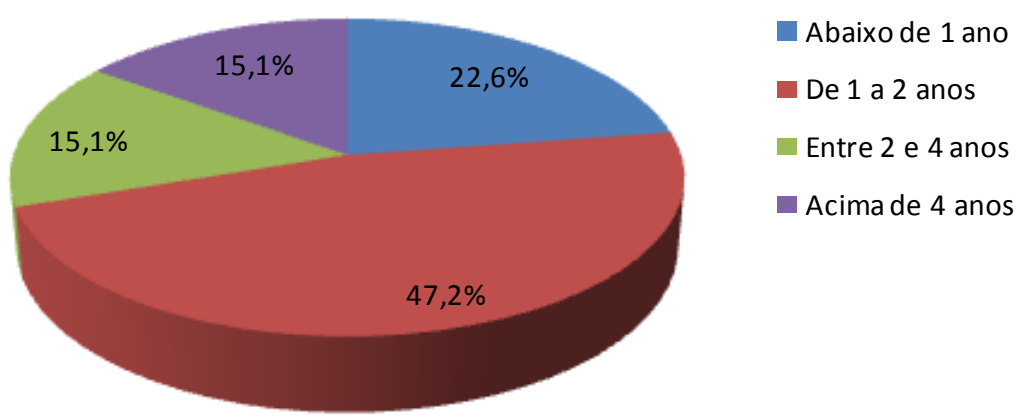

Gráfico 4 - Tempo de empresa

Como a maior parte das respostas encontra-se de 1 a 2 anos, pode-se concluir que os funcionários são relativamente novos na empresa.

Quanto ao tempo no cargo atual, 45,3\% responderam que estavam desempenhando sua função há menos de 1 ano. Já $41,5 \%$ responderam ter de 1 a 2 anos no cargo, 7,5\% entre 2 a 4 anos e os demais, acima de 4 anos como se pode observar a seguir no Gráfico 5.

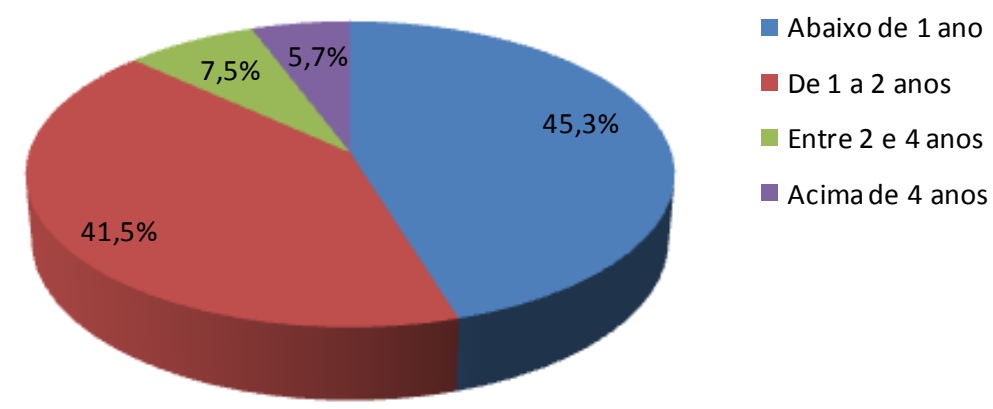

Gráfico 5 - Tempo no cargo atual

Quanto à escolaridade, grande parte dos respondentes, isto é, 75,5\%, possuíam curso superior. Em seguida, com 15,1\% estão os funcionários com Ensino Médio e por último, com 9,4\% estão os funcionários que possuíam pós-graduação. O Gráfico 6 exemplifica melhor os resultados. 


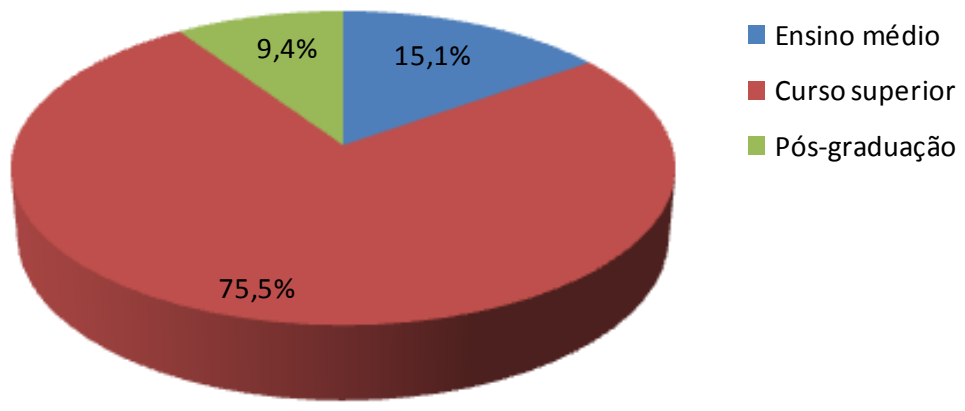

Gráfico 6 - Escolaridade

A Tabela 3 apresenta um resumo do perfil dos respondentes da pesquisa. Percebe-se que grande parte dos funcionários da empresa era jovens, de 20 a 29 anos, entraram na empresa há, no máximo, 2 anos, estava desempenhando sua função atual há menos de 1 ano e possuíam curso superior.

Tabela 3 - Médias e desvios padrão dos itens que compõem o dados demográficos

\begin{tabular}{l|c|c|c|c}
\hline \multicolumn{5}{|c}{ DADOS DEMOGRÁFICOS } \\
\hline & FAIXA ETÁRIA & $\begin{array}{c}\text { TEMPO DE } \\
\text { EMPRESA }\end{array}$ & $\begin{array}{c}\text { TEMPO NO } \\
\text { CARGO ATUAL }\end{array}$ & ESCOLARIDADE \\
\hline Média & $\begin{array}{c}2,23 \\
\text { (De } 20 \text { a } 30 \text { anos) }\end{array}$ & $\begin{array}{c}2,23 \\
\text { (De 1 a 2 anos) }\end{array}$ & $\begin{array}{c}1,73 \\
\text { (Abaixo de 1 ano) }\end{array}$ & $\begin{array}{c}1,94 \\
\text { (Curso Superior) }\end{array}$ \\
\hline Desvio Padrão & 0,42 & 0,97 & 0,84 & 0,50 \\
\hline
\end{tabular}

\subsection{Resultados e análise dos fatores de cultura organizacional}

A versão reduzida do Instrumento Brasileiro para Avaliação da Cultura Organizacional (IBACO) a qual foi utilizada na pesquisa avalia a cultura organizacional por meio de valores e práticas. Por meio da estratificação fatorial chegou- se as seguintes médias e desvios padrão conforme a Tabela 4: 
Tabela 4 - Médias e desvios padrão dos fatores de cultura organizacional de acordo com o IBACO

\begin{tabular}{l|c|c}
\hline \multicolumn{1}{c}{ VALORES } & MEDIA & DESVIO PADRÁO \\
\hline Profissionalismo cooperativo & 4,11 & 0,75 \\
\hline $\begin{array}{l}\text { Satisfação e bem-estar dos } \\
\text { empregados }\end{array}$ & 3,56 & 0,77 \\
\hline $\begin{array}{l}\text { Profissionalismo competitivo e } \\
\text { individualista }\end{array}$ & 3,39 & 0,53 \\
\hline \multicolumn{1}{c|}{ PRÁTICAS } & MÉDIA & DESVO PADRĀO \\
\hline $\begin{array}{l}\text { Integração externa } \\
\text { Recompensa e treinamento }\end{array}$ & 3,92 & 0,63 \\
\hline $\begin{array}{l}\text { Promoção do relacionamento } \\
\text { interpessoal }\end{array}$ & 3,40 & 0,66 \\
\hline
\end{tabular}

De acordo com as médias apresentadas na Tabela 4, pode-se concluir que o valor Profissionalismo cooperativo é bastante presente e predominante na empresa em estudo, pois sua média ficou acima de 4. Isso significa que a organização valoriza os funcionários que executam suas atividades com eficácia e competência, demonstrando colaboração, dedicação, profissionalismo e iniciativa. Além disso, contribuem para o alcance das metas comuns da empresa. Em seguida e razoavelmente presentes estão, primeiramente, o valor Satisfação e bem-estar dos empregados com média 3,56 e logo após, o valor Profissionalismo competitivo e individualista com 3,39.

Quanto à prática mais presente na empresa, a Integração externa foi a que alcançou maior média $(3,92)$. Dessa forma, práticas voltadas para o planejamento estratégico, para a tomada de decisão e para o atendimento ao cliente externo são as mais presentes e o foco dessas ações é de responsabilidade de superiores da organização. A segunda prática avaliada entre razoavelmente presente (3) e aplicase bastante (4) é a Recompensa e treinamento $(3,73)$ e a terceira é a Promoção do relacionamento interpessoal $(3,40)$ que se aplica razoavelmente.

Apesar de o fator profissionalismo cooperativo e o fator satisfação e bemestar dos empregados estarem bastante presentes na organização de acordo com as médias apresentadas, eles são, ao mesmo tempo, os fatores que tiveram maior 
variabilidade de resposta. O fator profissionalismo cooperativo apresentou desvio padrão de 0,75 e o fator satisfação e bem-estar dos empregados, 0,77.

A seguir são descritas as médias dos itens que compõem cada fator.

\subsubsection{Valor: profissionalismo cooperativo}

A partir da Tabela 5, é possível saber quais itens mais contribuíram para que o fator Profissionalismo cooperativo seja o mais presente na organização.

Tabela 5 - Médias e desvios padrão dos itens que compõem o fator profissionalismo cooperativo

PROFISSIONALISMO COOPERATIVO

\begin{tabular}{l|c|c}
\hline \multicolumn{1}{c|}{ AFIRMATIVAS } & MÉDIA & DESVIO PADRÃO \\
\hline $\begin{array}{l}\text { Item 17: O esforço e a dedicação ao trabalho } \\
\text { são qualidades bastante apreciadas. }\end{array}$ & 4,25 & 0,78 \\
\hline $\begin{array}{l}\text { Item 22: Os empregados que demonstram } \\
\text { dedicação e espírito de colaboração são os } \\
\text { melhores modelos a serem seguidos. }\end{array}$ & 4,19 & 0,90 \\
\hline $\begin{array}{l}\text { Item 14: A preocupação do empregado com } \\
\text { a qualidade de seu serviço é bem vista. }\end{array}$ & 4,17 & 0,85 \\
\hline $\begin{array}{l}\text { Item 21: A preocupação em superar as } \\
\text { dificuldades do dia-a-dia é vista como de } \\
\text { grande valor. }\end{array}$ & 3,98 & 1,05 \\
\hline $\begin{array}{l}\text { Item 19: O profissionalismo dos empregados } \\
\text { é visto como uma grande virtude. }\end{array}$ & 3,96 & 1,04 \\
\hline
\end{tabular}

Os itens 17, 22 e 14 foram os que mais contribuíram para que a média fosse 4,11 . Sendo assim, pode-se concluir que os funcionários acreditam que o esforço, a dedicação, a colaboração e a qualidade são importantes para execução de seu trabalho.

Considerando que a empresa julga o companheirismo, confiança e respeito mútuos componentes de sua cultura conforme informações do seu site, conclui-se que seus funcionários compartilham os mesmos valores.

A seguir, são apresentados os percentuais de cada resposta para o item 17: O esforço e a dedicação ao trabalho são qualidades bastante apreciadas, pois $43,4 \%$ responderam que o item se aplica totalmente na empresa. 


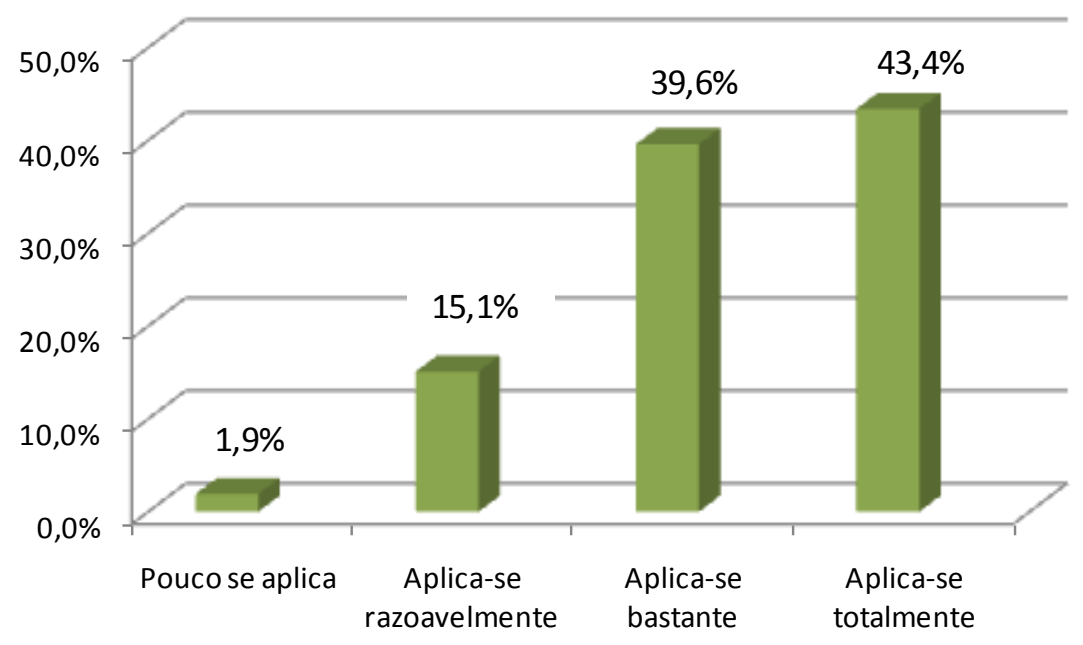

Gráfico 7 - Percentuais do item 17: O esforço e a dedicação ao trabalho são qualidades bastante apreciadas

A seguir são apresentados os percentuais de cada resposta para o item 22: Os empregados que demonstram dedicação e espírito de colaboração são os melhores modelos a serem seguidos, uma vez que $47,2 \%$ dos funcionários responderam que o item se aplica totalmente na empresa.

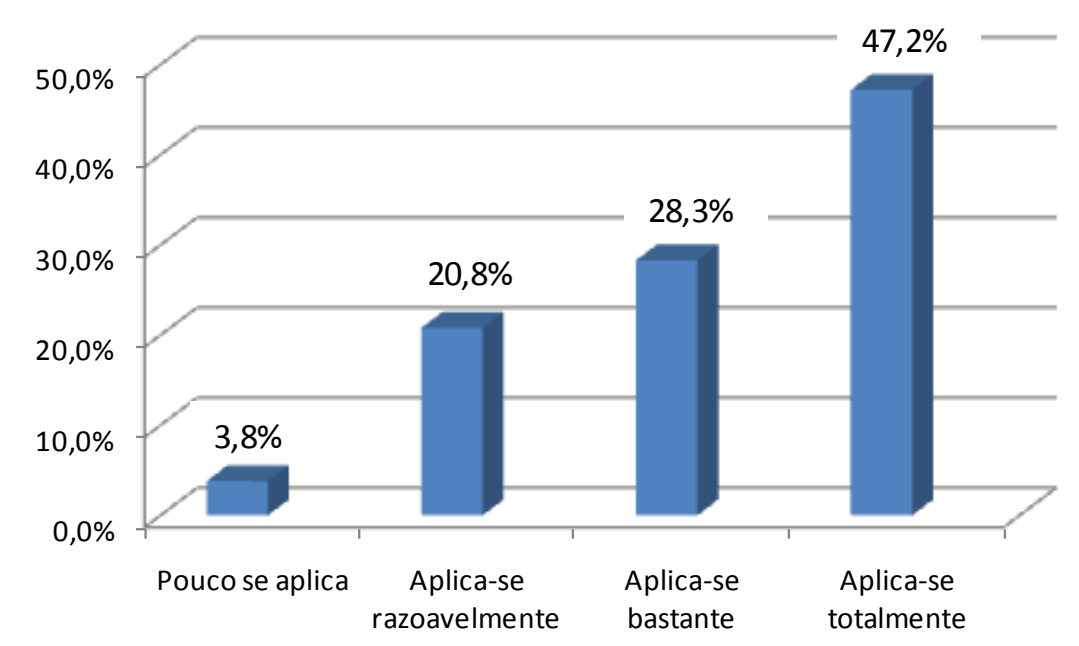

Gráfico 8 - Percentuais do item 22: Os empregados que demonstram dedicação e espírito de colaboração são os melhores modelos a serem seguidos

Já no Gráfico 9 são apresentados os percentuais de cada resposta para o item 14: A preocupação do empregado com a qualidade de seu serviço é bem vista. Constatou-se que $43,4 \%$ dos funcionários responderam que 0 item se aplica bastante na empresa. 


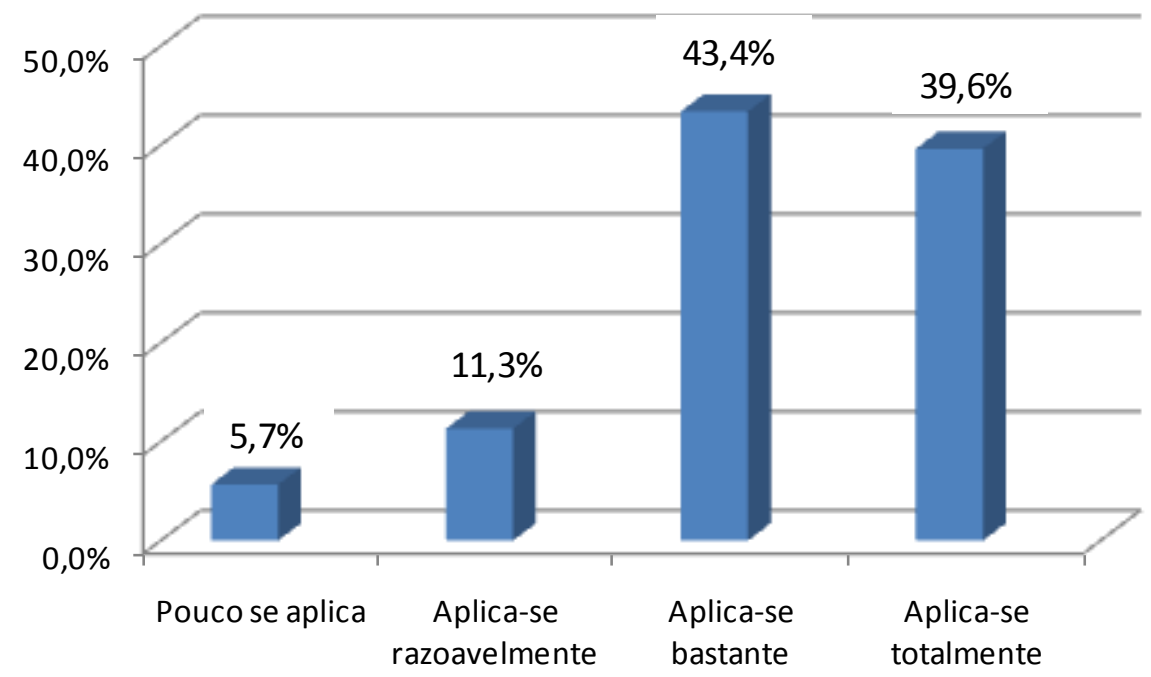

Gráfico 9 - Percentuais do item 14: A preocupação do empregado com a qualidade de seu serviço é bem vista

A seguir são apresentados os percentuais de cada resposta para o item 21: A preocupação em superar as dificuldades do dia-a-dia é vista como de grande valor, pois se observa que $39,6 \%$ dos funcionários responderam que o item se aplica bastante na empresa.

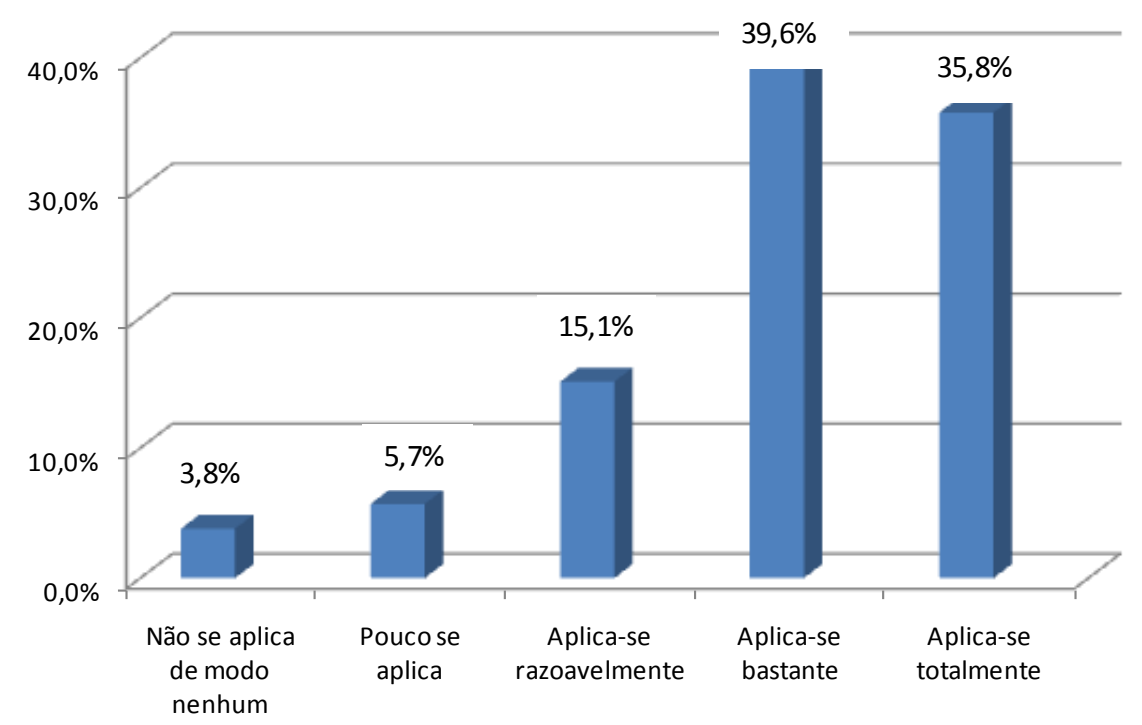

Gráfico 10 - Percentuais do item 21: A preocupação em superar as dificuldades do dia-a-dia é vista como de grande valor

Por fim, no Gráfico 11, são apresentados os percentuais de cada resposta para o item 19: O profissionalismo dos empregados é visto como uma grande virtude, sendo que $35,8 \%$ dos funcionários responderam que 0 item se aplica bastante e se aplica totalmente na empresa. 


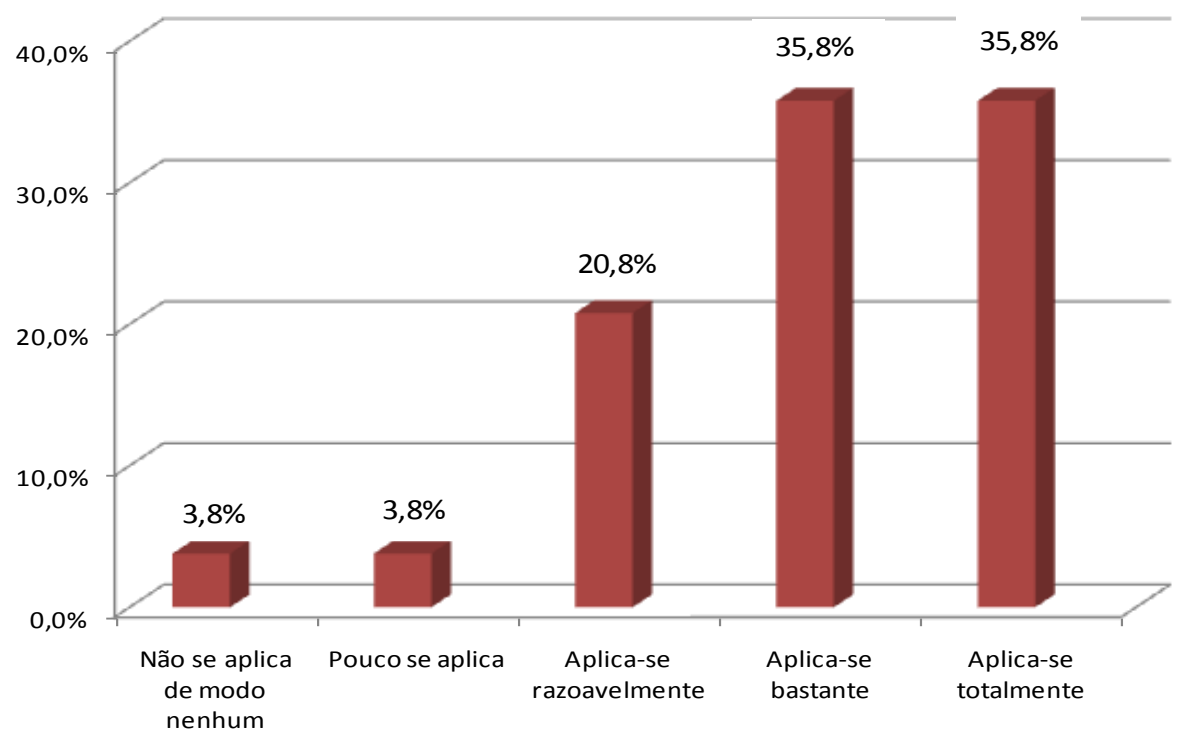

Gráfico 11 - Percentuais do item 19: O profissionalismo dos empregados é visto como uma grande virtude

\subsubsection{Valor: satisfação e bem-estar dos empregados}

A partir da Tabela 6, é possível saber quais itens mais contribuíram para que o fator Satisfação e bem-estar dos empregados fosse o segundo valor mais presente na empresa.

Tabela 6 - Médias e desvios padrão dos itens que compõem o fator satisfação e bem-estar dos empregados

\begin{tabular}{l|c|c}
\hline \multicolumn{1}{c}{ SATISFAÇÃO E BEM-ESTAR DOS EMPREGADOS } \\
\hline \multicolumn{1}{c}{ AFIRMATIVAS } & MÉDIA & DESVIO PADRÃO \\
\hline $\begin{array}{l}\text { Item 6: Investe-se no crescimento } \\
\text { profissional dos empregados. }\end{array}$ & 3,85 & 0,99 \\
\hline $\begin{array}{l}\text { Item 3: As necessidades pessoais e o bem- } \\
\text { estar dos funcionários constituem uma } \\
\text { preocupação constante da empresa. }\end{array}$ & 3,83 & 1,00 \\
\hline $\begin{array}{l}\text { Item 12: Programas para aumentar a } \\
\text { satisfação dos empregados são } \\
\text { regularmente desenvolvidos. }\end{array}$ & 3,62 & 1,06 \\
\hline $\begin{array}{l}\text { Item 10: Os empregados recebem } \\
\text { treinamento para poderem desenvolver a } \\
\text { criatividade. }\end{array}$ & 3,30 & 1,12 \\
\hline $\begin{array}{l}\text { Item 18: Programas destinados a melhorar o } \\
\text { bem-estar dos empregados são } \\
\text { implementados e testados. }\end{array}$ & 3,21 & 0,97 \\
\hline
\end{tabular}


Os itens 3 e 6 foram os que mais contribuíram para que a média fosse 3,56. Dessa forma, pode-se concluir que a empresa investe no crescimento profissional de seus funcionários, o que pode contribuir para um maior aprendizado. Além disso, se preocupa com as necessidades e bem-estar de seus funcionários. Como para empresa, uns dos tópicos importantes de sua cultura é o diferencial competitivo que empregados bem treinados trazem para ela, percebe-se pelo resultado da pesquisa que esse tópico é valorizado e percebido pelos funcionários.

A Tabela 6 também mostra que a empresa se preocupa com o bem-estar dos empregados, porém a média mais baixa foi relativa ao item relacionado à implementação de programas relacionados a esse tema. Com isso, é possível concluir que por mais que a empresa tenha preocupação, ela não desenvolve o tema na prática ou não possui programas com tal finalidade.

A seguir, são apresentados os percentuais de cada resposta para o item 6: Investe-se no crescimento profissional dos empregados, em que 41,5\% responderam que o item se aplica bastante na empresa.

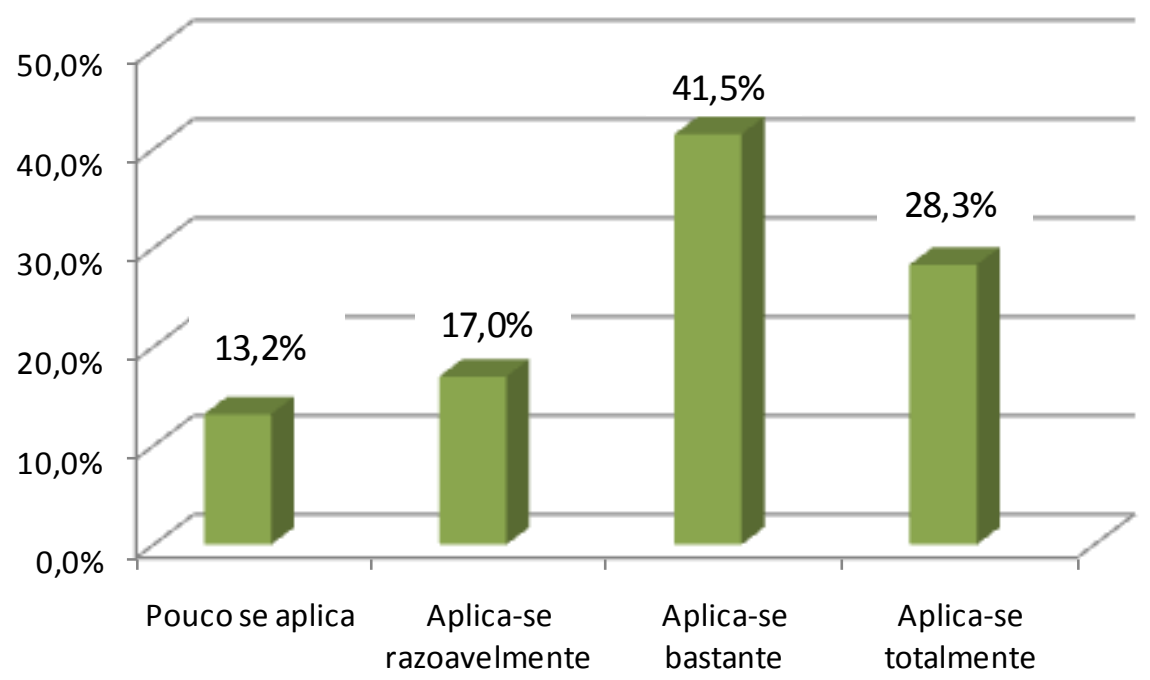

Gráfico 12 - Percentuais do item 6: Investe-se no crescimento profissional dos empregados

Já no Gráfico 13 são apresentados os percentuais de cada resposta para o item 3: as necessidades pessoais e o bem-estar dos funcionários constituem uma preocupação constante da empresa. Dos respondentes, 34\% acreditam que o item se aplica bastante na empresa. 


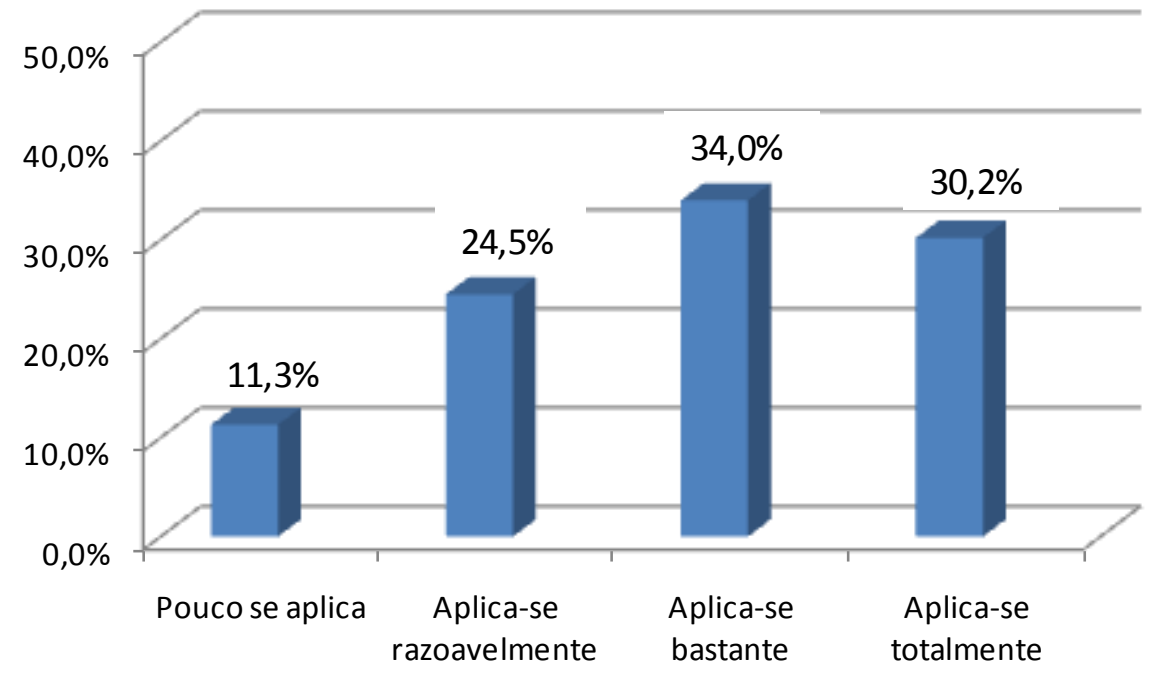

Gráfico 13 - Percentuais do item 3: As necessidades pessoais e o bem-estar dos funcionários constituem uma preocupação constante da empresa

Ao analisar os percentuais de cada resposta para o item 12: programas para aumentar a satisfação dos empregados são regularmente desenvolvidos, nota-se que $39,6 \%$ responderam que o item se aplica bastante na empresa conforme Gráfico 14.

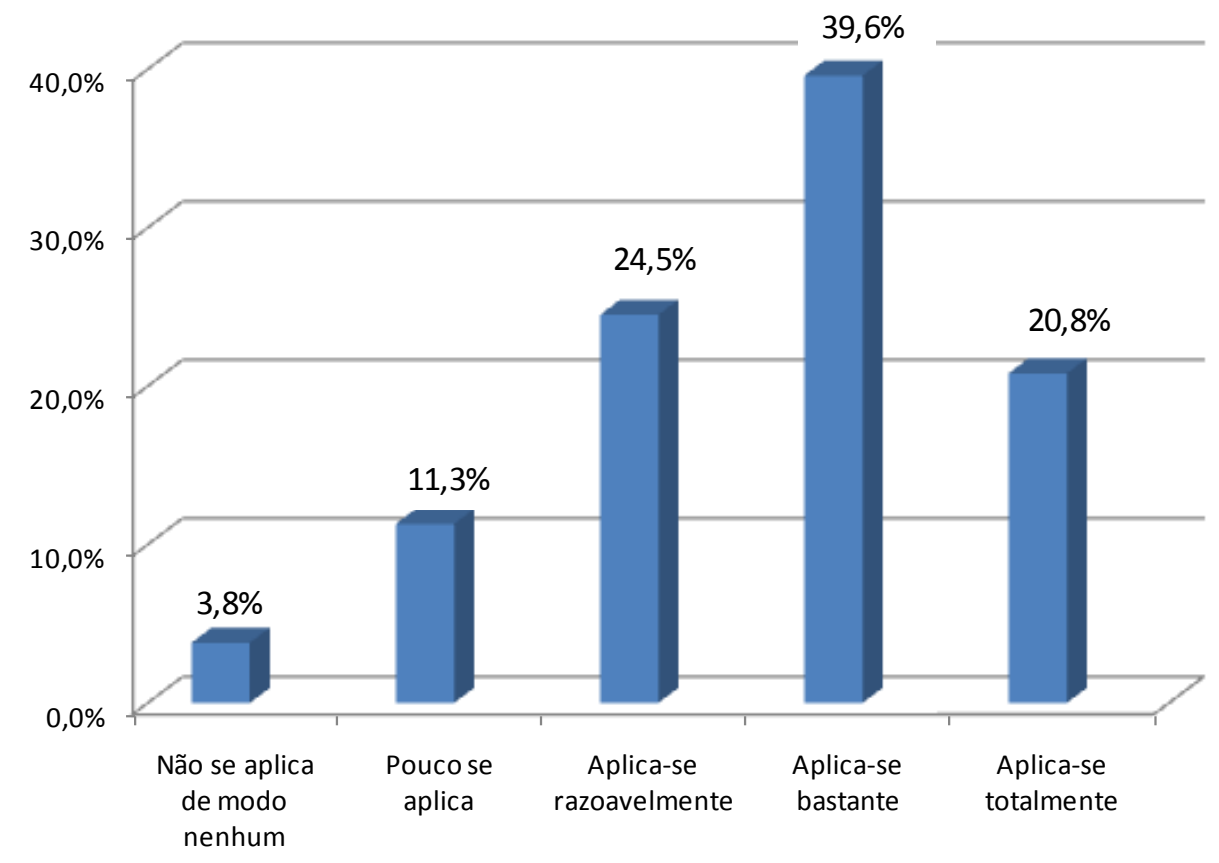

Gráfico 14 - Percentuais do item 12: Programas para aumentar a satisfação dos empregados são regularmente desenvolvidos

A seguir, encontram-se os percentuais de cada resposta para o item 10: os empregados recebem treinamento para poderem desenvolver a criatividade. Dos 
respondentes, 30,3\% acreditam que o item é razoavelmente aplicado na Empresa, o que mostra que a criatividade não é estimulada por meio de treinamento dado pela Empresa o quanto ela gostaria.

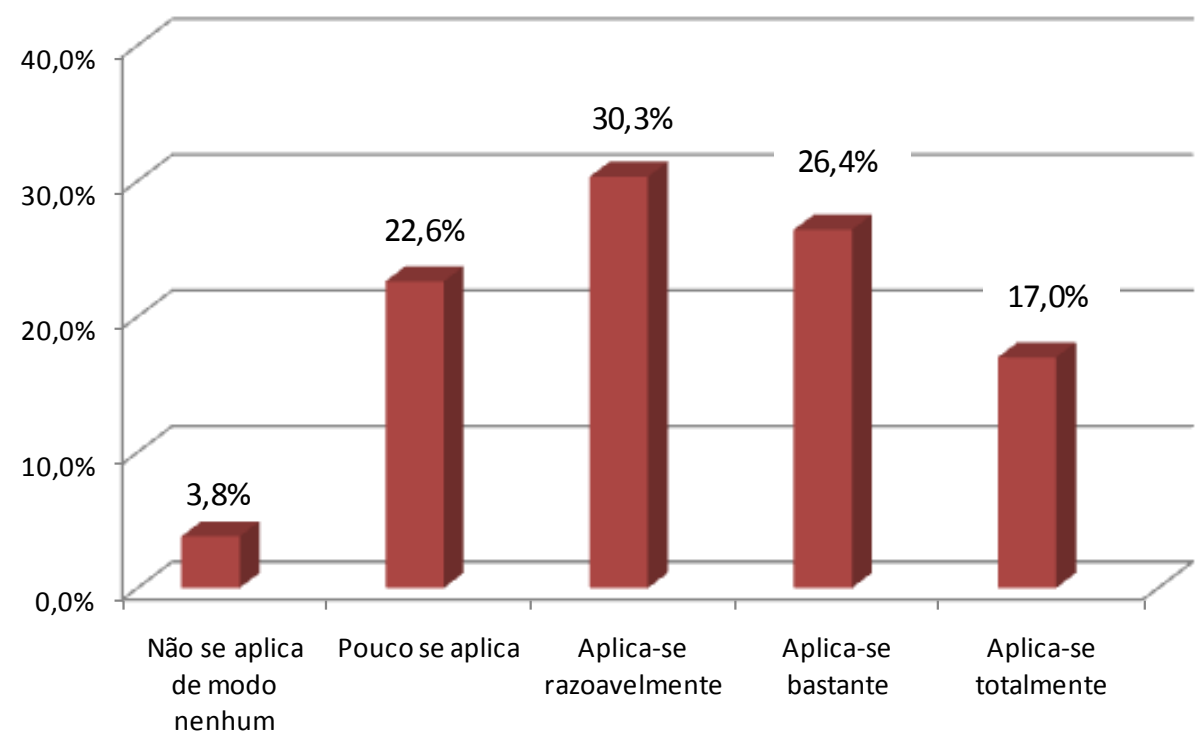

Gráfico 15 - Percentuais do item 10: Os empregados recebem treinamento para poderem desenvolver a criatividade

O Gráfico 16 apresenta os percentuais de cada resposta para o item 18: programas destinados a melhorar o bem-estar dos empregados são implementados e testados. Percebe-se que $49,1 \%$ responderam que o item se aplica razoavelmente na empresa.

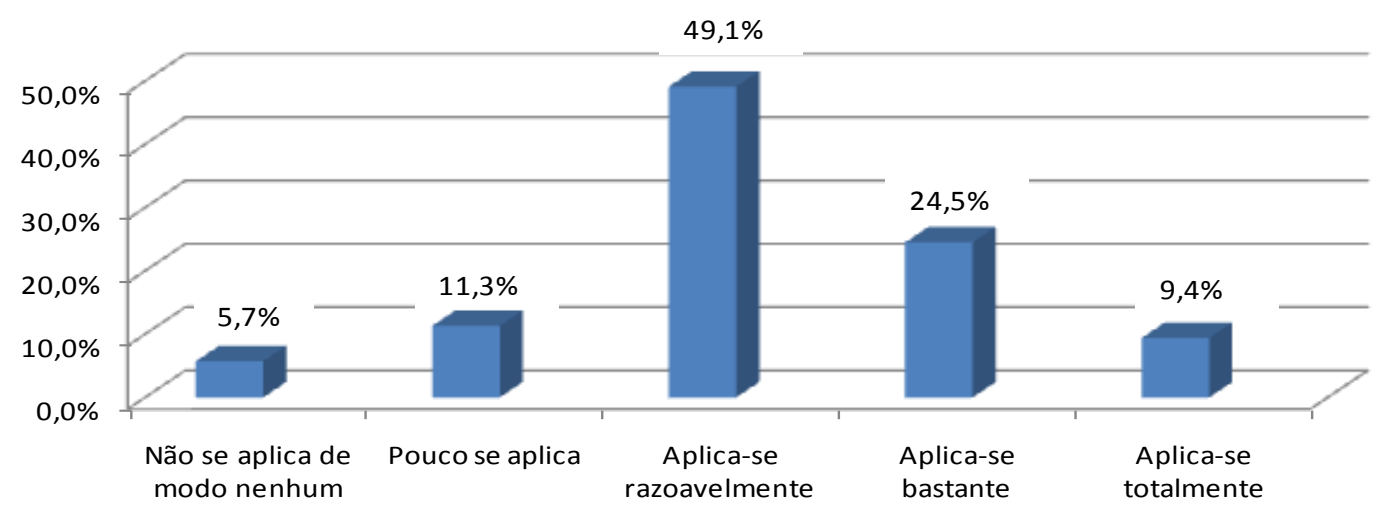

Gráfico 16 - Percentuais do item 18: Programas destinados a melhorar o bem-estar dos empregados são implementados e testados 
4.3.3. Valor: profissionalismo competitivo e individualista

A partir da Tabela 7, é possível saber a contribuição de cada item do fator Profissionalismo competitivo e individualista para que ele alcançasse a média de 3,39, ou seja, o fator menos presente na empresa.

Tabela 7 - Médias e desvios padrão dos itens que compõem o fator profissionalismo competitivo e individualista

\begin{tabular}{l|c|c}
\hline \multicolumn{1}{c}{ PROFISSIONALISMO COMPETITIVO E INDIVIDUALISTA } \\
\hline \multicolumn{1}{c}{ AFIRMATIVAS } & MÉDIA & DESVIO PADRÃO \\
\hline $\begin{array}{l}\text { Item 25: O crescimento profissional é } \\
\text { considerado indispensável à permanência } \\
\text { do empregado na casa. }\end{array}$ & 4,42 & 0,54 \\
\hline $\begin{array}{l}\text { Item 30: A competição é vista como } \\
\text { indispensável à obtenção de bons } \\
\text { resultados. }\end{array}$ & 4,21 & \\
\hline $\begin{array}{l}\text { Item 24: A criatividade é um dos requisitos } \\
\text { básicos para a ocupação de cargos } \\
\text { gerenciais. }\end{array}$ & 3,17 & \\
\hline $\begin{array}{l}\text { Item 29: A competição é valorizada, mesmo } \\
\text { que de forma não sadia, porque o objetivo } \\
\text { maior da empresa é a produtividade e lucro. }\end{array}$ & 2,89 & 1,14 \\
\hline $\begin{array}{l}\text { Item 23: Somente os bons empregados } \\
\text { recebem benefícios que Ihes garantem um } \\
\text { melhor bem-estar. }\end{array}$ & 2,26 & 1,34 \\
\hline
\end{tabular}

Os itens 25 e 30 foram os que mais contribuíram para que a média fosse 3,39. Sendo assim, pode-se concluir que os funcionários acreditam que o crescimento profissional é fundamental para seu trabalho e que há competição no ambiente empresarial e isso auxilia a obtenção de bons resultados.

De acordo com a Tabela 7 , os funcionários acreditam que é fundamental crescer profissionalmente para permanecer na empresa. Isso corrobora com a ideia que a empresa tem de que o crescimento de seus funcionários é importante e acontece de acordo com o mérito de cada um. Quanto à competição, a empresa não valoriza uma forma desleal de concorrência interna corroborando também com ideia defendida pela empresa de que todos devem respeitar regras e não fazer malandragem para atingir melhores resultados. 
A seguir são apresentados os percentuais de cada resposta para o item 25: o crescimento profissional é considerado indispensável à permanência do empregado na casa. 54,7\% responderam que o item se aplica bastante na empresa.

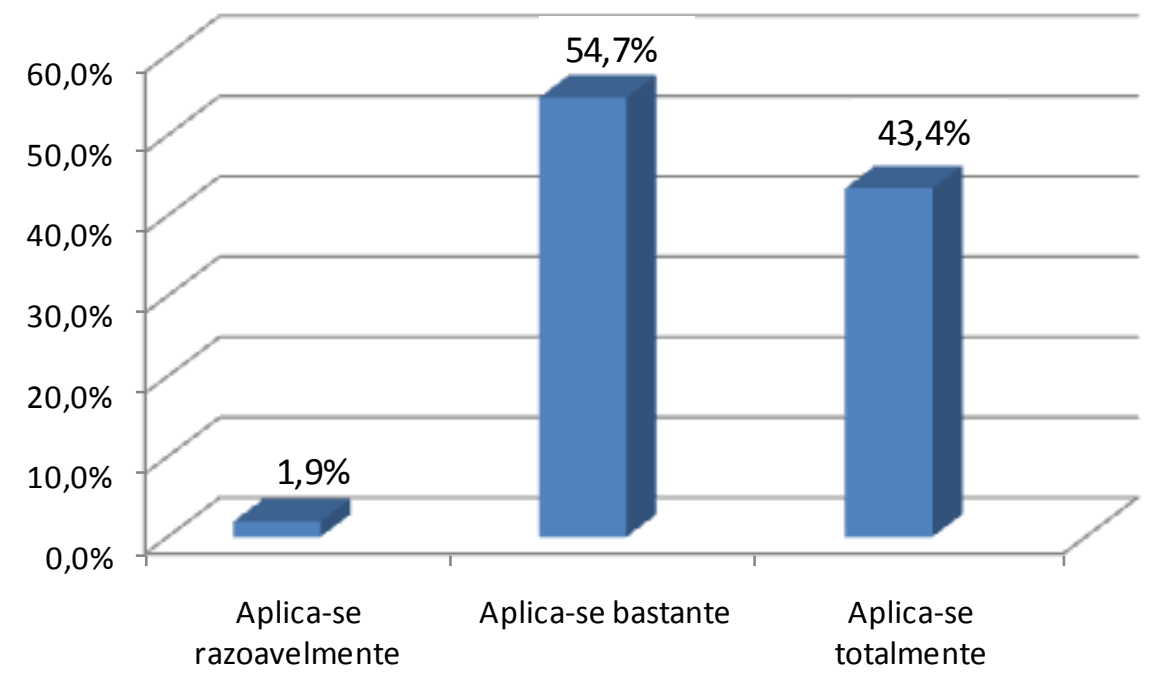

Gráfico 17 - Percentuais do item 25: O crescimento profissional é considerado indispensável à permanência do empregado na casa

No Gráfico 18, os percentuais de cada resposta para o item 30: a competição é vista como indispensável à obtenção de bons resultados, são apresentados. Assim, 47,2\% responderam que o item se aplica totalmente na empresa.

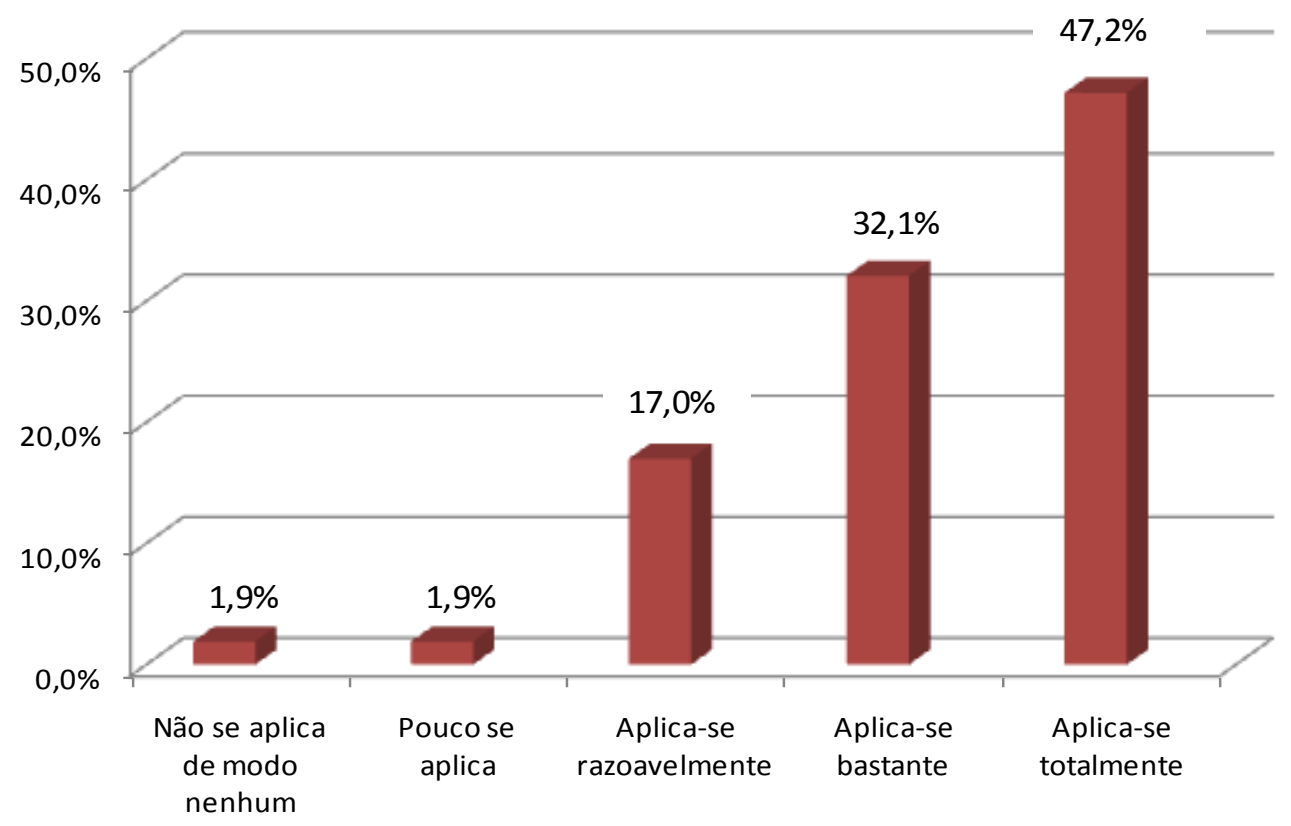

Gráfico 18 - Percentuais do item 30: A competição é vista como indispensável à obtenção de bons resultados 
A partir do Gráfico 19, observa-se que 32,1\% responderam que o item 24: a criatividade é um dos requisitos básicos para a ocupação de cargos gerenciais, se aplica razoavelmente na empresa, pois a natureza da atividade exercida pelos profissionais não exige criatividade.

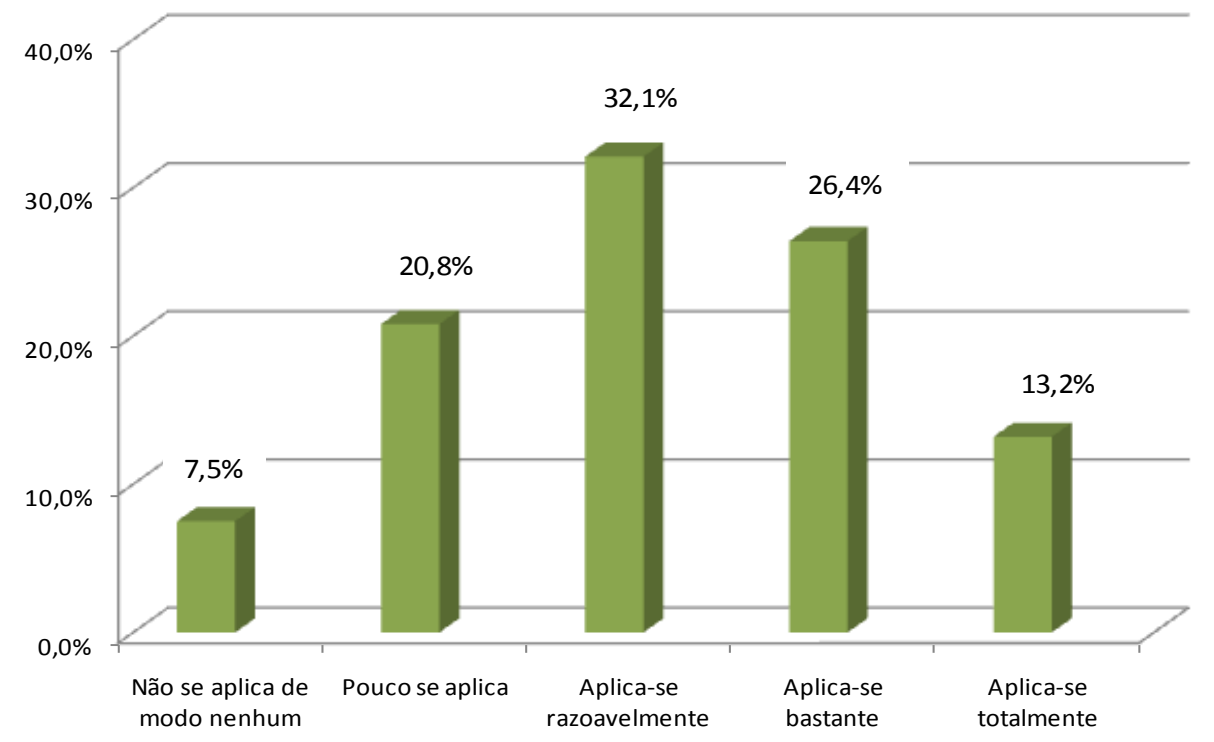

Gráfico 19 - Percentuais do item 24: A criatividade é um dos requisitos básicos para a ocupação de cargos gerenciais

A seguir são apresentados os percentuais de cada resposta para o item 29: A competição é valorizada, mesmo que de forma não sadia, porque o objetivo maior da empresa é a produtividade e lucro. Do total de respondentes, $26,4 \%$ responderam que o item se aplica pouco na empresa e $24,5 \%$ responderam que ele razoavelmente se aplica.

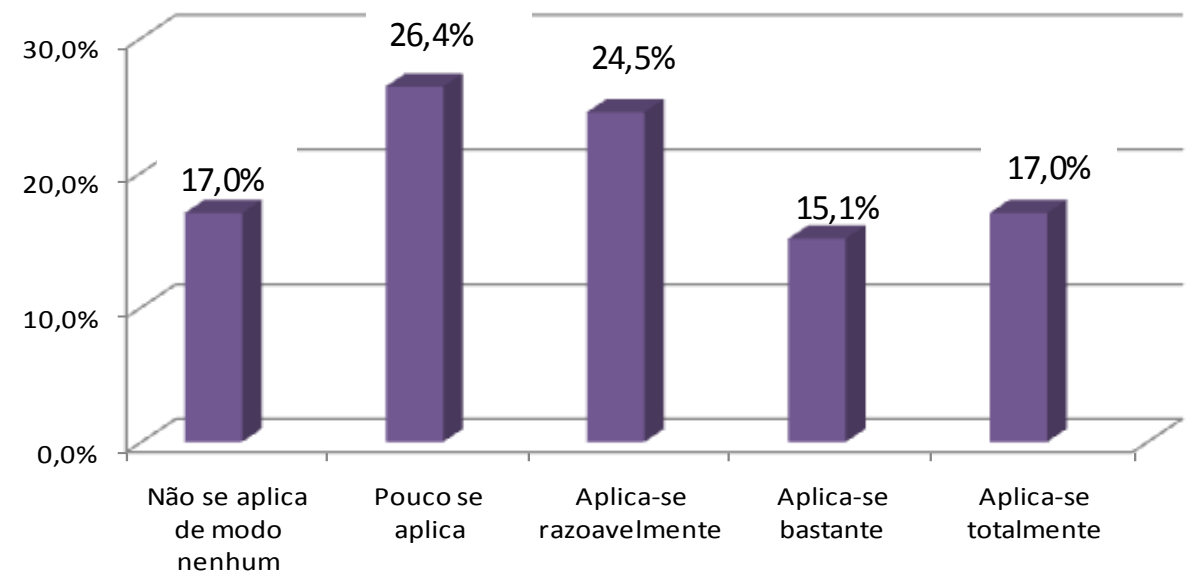

Gráfico 20 - Percentuais do item 29: A competição é valorizada, mesmo que de forma não sadia, porque o objetivo maior da empresa é a produtividade e lucro 
Por último, no Gráfico 21, são apresentados os percentuais de cada resposta para o item 23: somente os bons empregados recebem benefícios que lhes garantem um melhor bem-estar. Dos participantes da pesquisa, 43,4\% acreditam que o item não se aplica de modo nenhum na empresa.

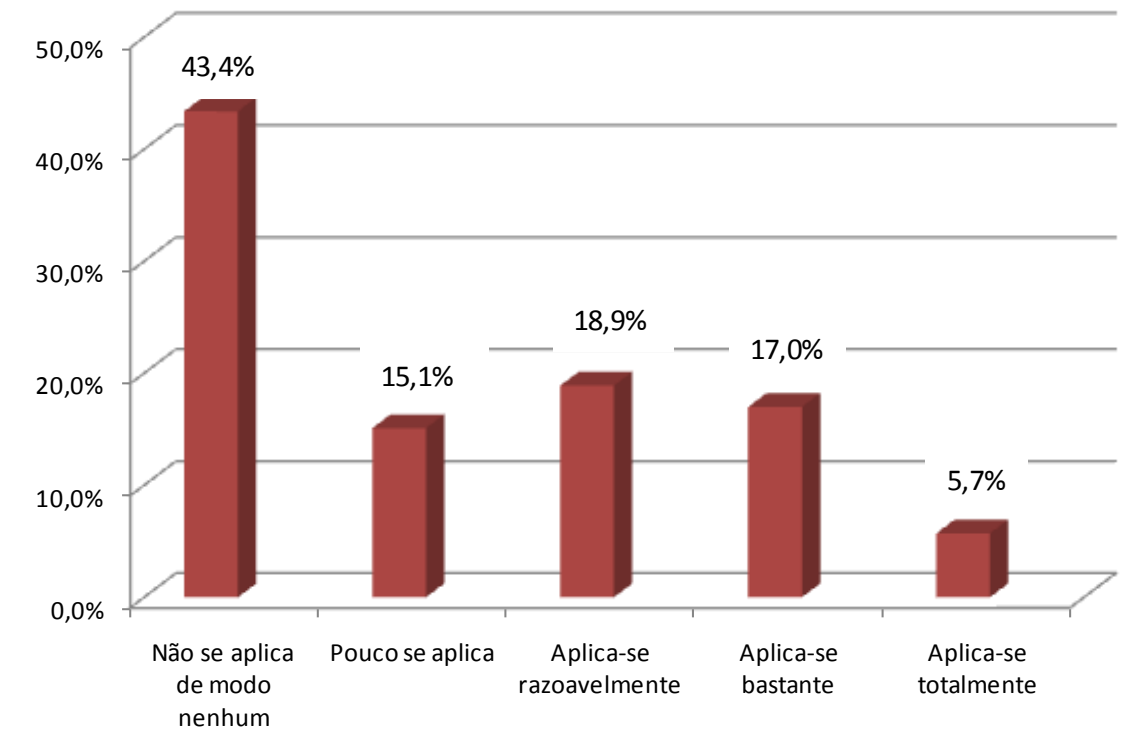

Gráfico 21 - Percentuais do item 23: Somente os bons empregados recebem benefícios que thes garantem um melhor bem-estar

\subsubsection{Prática: integração externa}

A Tabela 8 a seguir apresenta a contribuição de cada item do fator Integração externa para que ele alcançasse a média de 3,92 e com isso se tornasse a prática mais presente na empresa.

Tabela 8 - Médias e desvios padrão dos itens que compõem o fator integração externa 
Tabela 8 - Médias e desvios padrão dos itens que compõem o fator integração externa INTEGRAÇÃO EXTERNA

\begin{tabular}{l|c|c}
\hline \multicolumn{1}{c|}{ AFIRMATIVAS } & MÉDIA & DESVIO PADRÃO \\
\hline $\begin{array}{l}\text { Item 4: Persegue-se a excelência de } \\
\text { produtos e serviços como forma de } \\
\text { satisfazer aos clientes. }\end{array}$ & 4,38 & 0,79 \\
\hline $\begin{array}{l}\text { Item 15: As inovações são em geral } \\
\text { introduzidas para atender às necessidades } \\
\text { do mercado. }\end{array}$ & 4,13 & 0,76 \\
\hline $\begin{array}{l}\text { Item 8: Mantêm-se relações amigáveis com } \\
\text { os clientes. }\end{array}$ & 3,89 & 0,73 \\
\hline $\begin{array}{l}\text { Item 2: O atendimento às necessidades do } \\
\text { cliente é uma das metas mais importantes. }\end{array}$ & 3,72 & 1,01 \\
\hline $\begin{array}{l}\text { Item 7: O acompanhamento e atendimento } \\
\text { das necessidades dos clientes é feito } \\
\text { constantemente. }\end{array}$ & 3,51 & 1,03 \\
\hline
\end{tabular}

As respostas dadas aos itens 4 e 15 foram as que mais contribuíram para que o fator integração externa fosse o segundo fator mais presente na organização e a prática mais percebida por todos. Dessa forma, pode-se concluir que faz parte da cultura da empresa a preocupação com a qualidade de seus produtos e de seu atendimento com o intuito de satisfazer seus clientes e que para isso seja possível, são introduzidas ações que são demandadas pelo mercado.

Um dos itens da cultura da empresa é a preocupação constante com a qualidade dos produtos e com a satisfação dos consumidores e clientes. A partir da Tabela 8 é possível perceber que os funcionários da empresa acreditam que realmente esse item faz parte do dia-a-dia deles, compondo a cultura da empresa.

A seguir são apresentados os percentuais de cada resposta para o item 4: persegue-se a excelência de produtos e serviços como forma de satisfazer aos clientes. A resposta mais recorrente foi "aplica-se totalmente" com 52,8\%. 


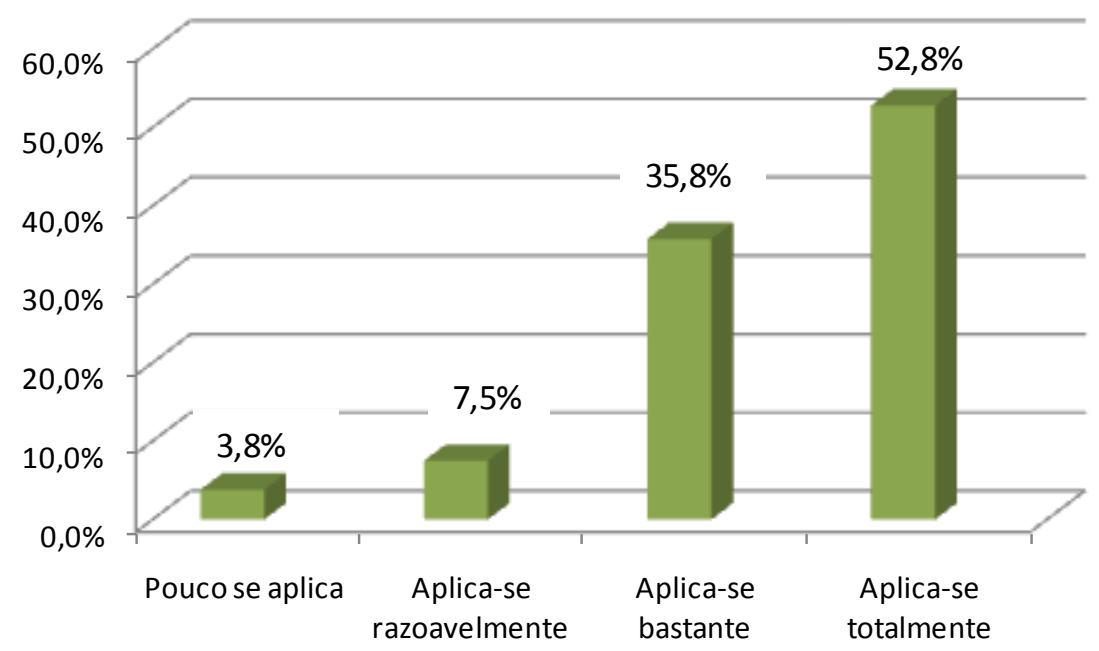

Gráfico 22 - Percentuais do item 4: Persegue-se a excelência de produtos e serviços como forma de satisfazer aos clientes

O Gráfico 23 apresenta os percentuais das respostas para o item 15: As inovações são em geral introduzidas para atender às necessidades do mercado. Do total de sujeitos, $41,5 \%$ responderam que o item se aplica bastante na empresa.

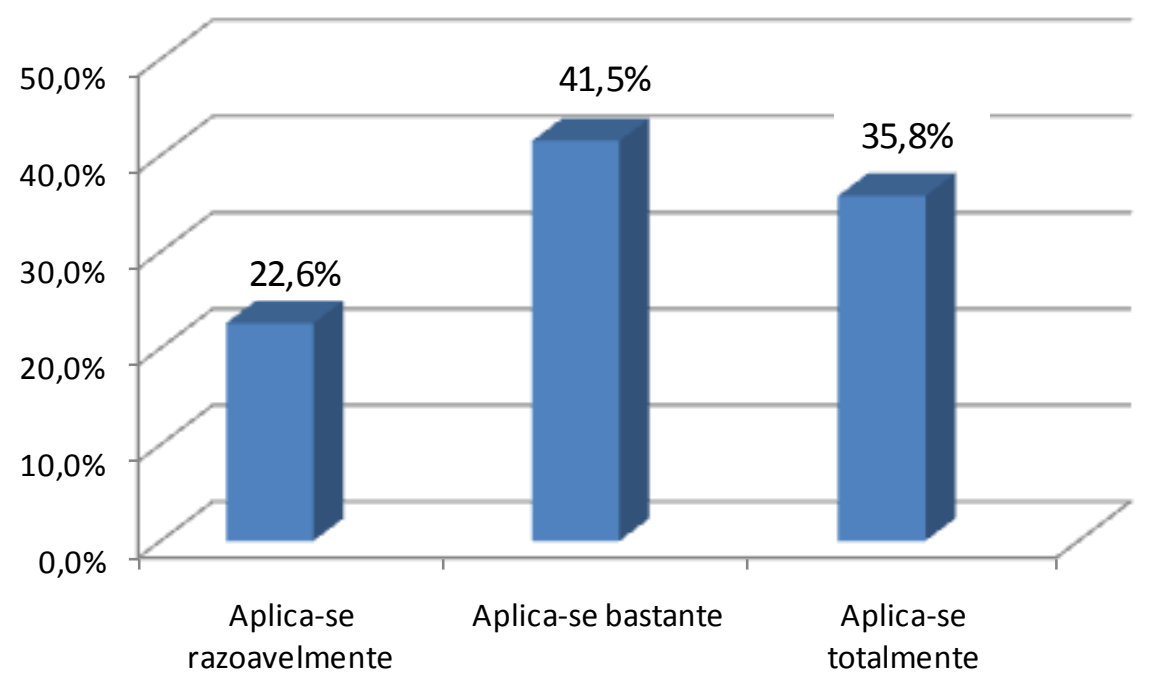

Gráfico 23 - Percentuais do item 15: As inovações são em geral introduzidas para atender às necessidades do mercado

De acordo com o Gráfico 24, 52,8\% dos funcionários responderam "aplica-se bastante" para o item 8, mantêm-se relações amigáveis com os clientes. 


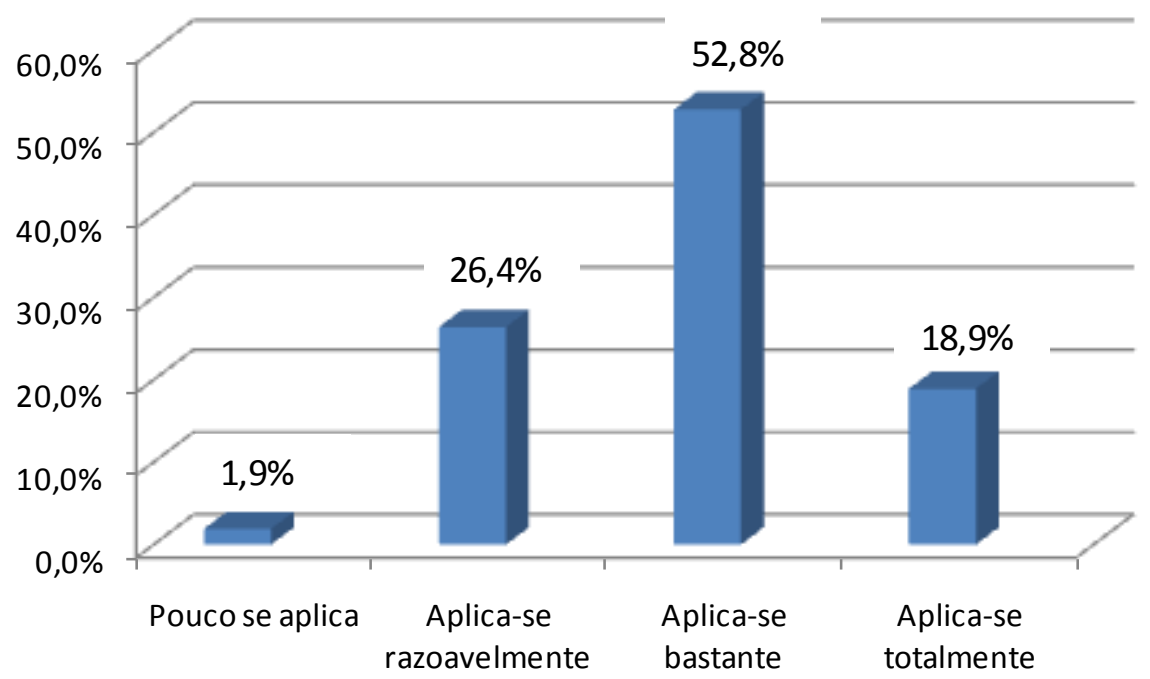

Gráfico 24 - Percentuais do item 8: Mantêm-se relações amigáveis com os clientes

No Gráfico 25 são apresentados os percentuais de cada resposta para o item 2: O atendimento às necessidades do cliente é uma das metas mais importantes. Dos respondentes, 37,7\% acreditam que o item se aplica bastante na empresa.

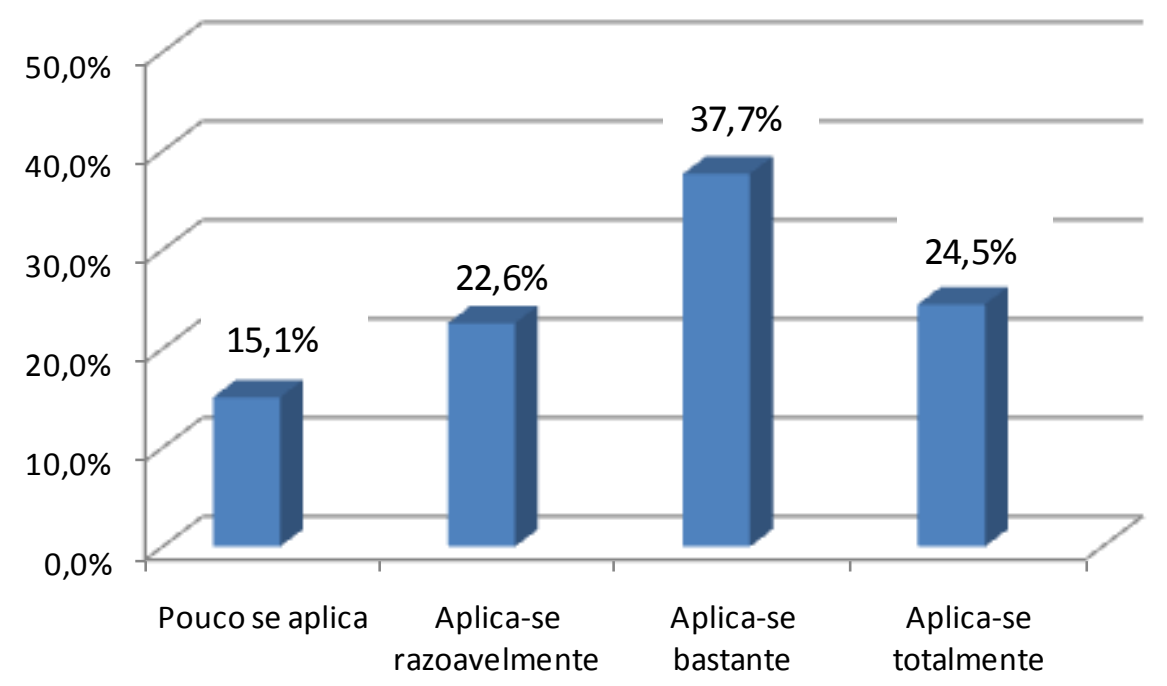

Gráfico 25 - Percentuais do item 2: O atendimento às necessidades do cliente é uma das metas mais importantes

Por fim, são apresentados no Gráfico 26 os percentuais das respostas para o item 7 (o acompanhamento e atendimento das necessidades dos clientes é feito constantemente), em que $37,7 \%$ dos funcionários responderam que o item se aplica razoavelmente na empresa. 


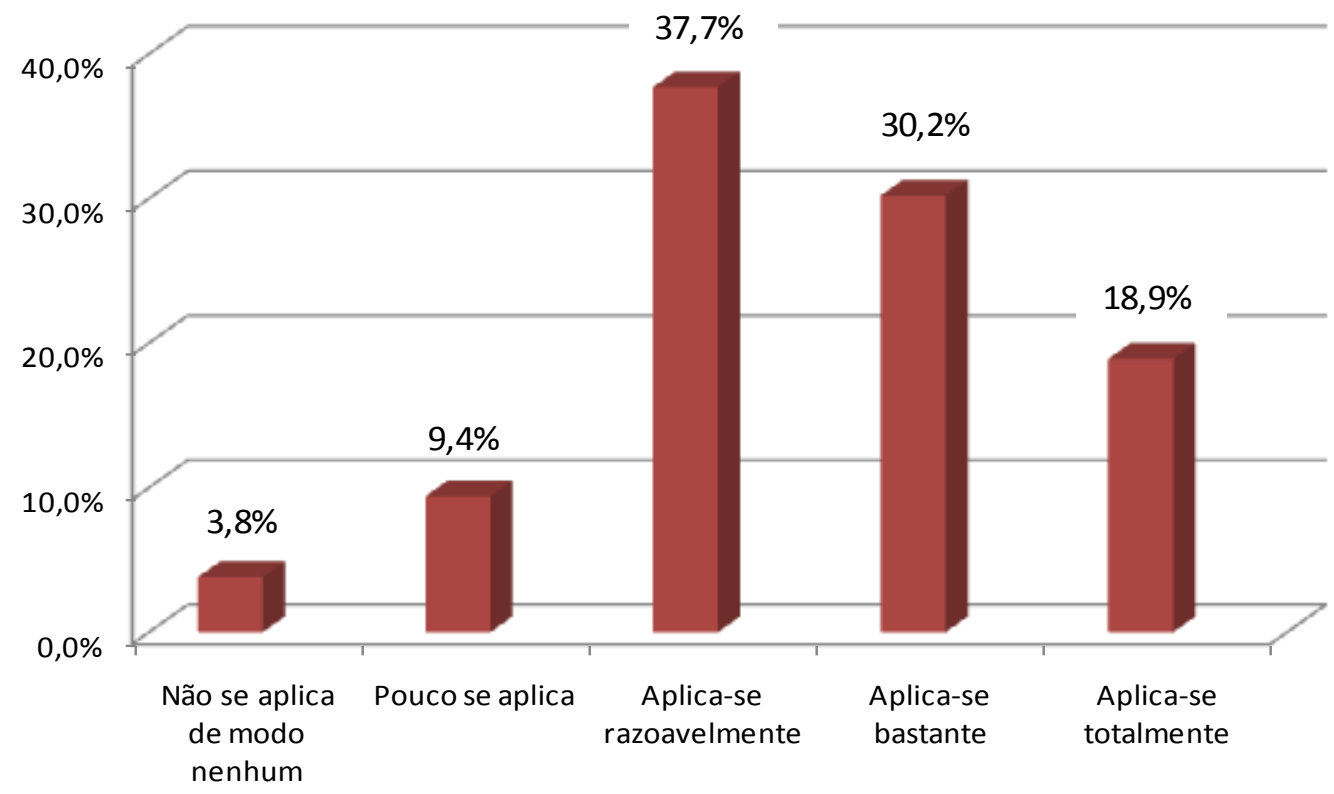

Gráfico 26 - Percentuais do item 7: O acompanhamento e atendimento das necessidades dos clientes é feito constantemente

\subsubsection{Prática: recompensa e treinamento}

Os itens que formam a prática Recompensa e treinamento são apresentados na Tabela 9 com suas respectivas médias. Com isso é possível observar a contribuição desses itens para a média do fator $(3,73)$.

Tabela 9 - Médias e desvios padrão dos itens que compõem o fator recompensa e treinamento RECOMPENSA E TREINAMENTO

\begin{tabular}{l|c|c}
\hline \multicolumn{1}{c|}{ AFIRMATIVAS } & MÉDIA & DESVIO PADRÃO \\
\hline $\begin{array}{l}\text { Item 11: Os empregados são premiados } \\
\text { quando apresentam um desempenho que se } \\
\text { destaca dos demais. }\end{array}$ & 4,30 & 0,87 \\
\hline $\begin{array}{l}\text { Item 28: Os empregados costumam ser } \\
\text { premiados quando alcançam metas pré- } \\
\text { estabelecidas. }\end{array}$ & 4,26 & 1,06 \\
\hline $\begin{array}{l}\text { Item 5: Os empregados que apresentam } \\
\text { idéias inovadoras constumam ser } \\
\text { premiados. }\end{array}$ & 3,68 & 1,03 \\
\hline $\begin{array}{l}\text { Item 16: Eventos sociais com distribuição de } \\
\text { brindes são comumente realizados para os } \\
\text { empregados. }\end{array}$ & 3,23 & 1,12 \\
\hline $\begin{array}{l}\text { Item 26: As inovações costumam ser } \\
\text { introduzidas através de programas de } \\
\text { qualidade. }\end{array}$ & 3,17 & 0,83 \\
\hline
\end{tabular}


As respostas dadas aos itens 11 e 28 foram as que mais contribuíram para que o fator recompensa e treinamento se tornasse a segunda prática mais utilizada na Organização. A partir dos resultados da Tabela 10, percebe-se que a Empresa procura premiar e recompensar os funcionários que atingem metas e têm desempenho muito bom. Os resultados corroboram e confirmam a existência de meritocracia na organização. Premiações estimulam melhores resultados e quem tem bom desempenho é promovido na empresa.

Os três itens com menores médias da Tabela 9 mostram que a empresa precisa investir em treinamento e que apesar desse tema fazer parte da cultura que a empresa deseja cultivar, na prática isso nem sempre acontece. Além disso, os funcionários acreditam que a Empresa não estimula ideias inovadoras, portanto, possivelmente, comprometendo a criatividade.

A seguir são apresentados os percentuais de cada resposta para o item 11: os empregados são premiados quando apresentam um desempenho que se destaca dos demais. A resposta mais recorrente foi "aplica-se totalmente" com 50,9\%.

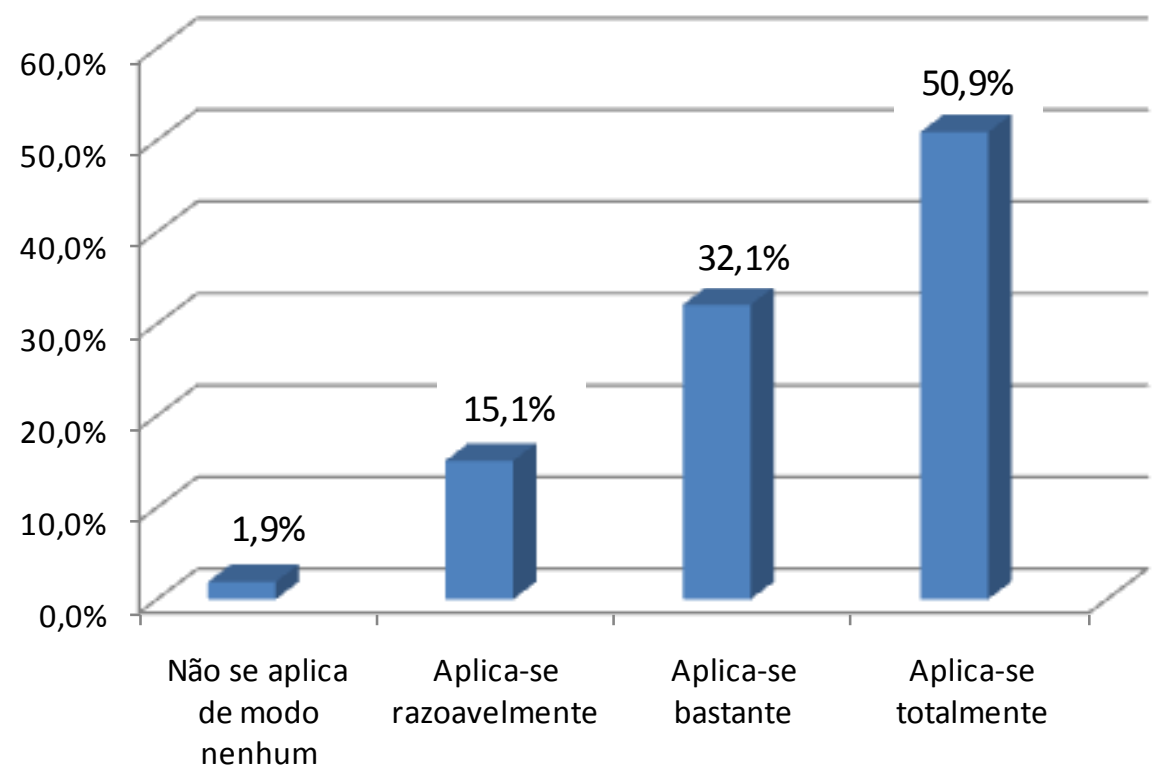

Gráfico 27 - Percentuais do item 11: Os empregados são premiados quando apresentam um desempenho que se destaca dos demais

De acordo com o Gráfico 28 e em relação ao item 28: os empregados costumam ser premiados quando alcançam metas pré-estabelecidas, sendo que $54,7 \%$ dos respondentes acreditam que a afirmativa se aplica totalmente na empresa. 


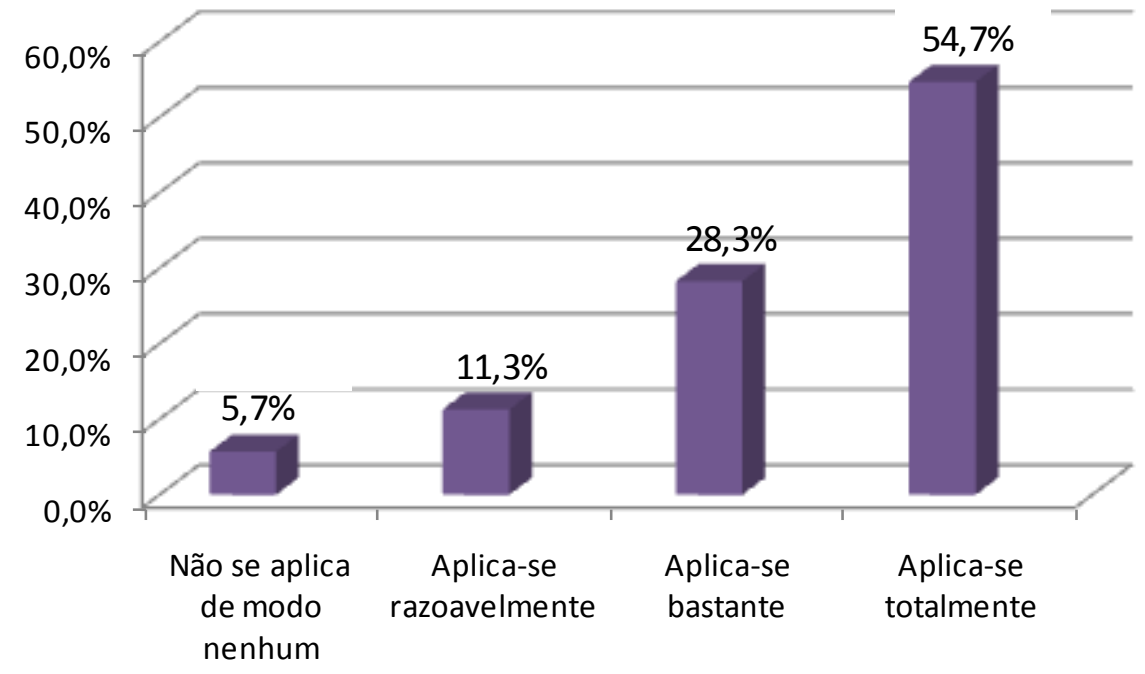

Gráfico 28 - Percentuais do item 28: Os empregados costumam ser premiados quando alcançam metas pré-estabelecidas

Já quanto ao item 5, os empregados que apresentam ideias inovadoras costumam ser premiados, sendo que $43,4 \%$ responderam que aplica-se bastante na empresa, como mostra o Gráfico 29.

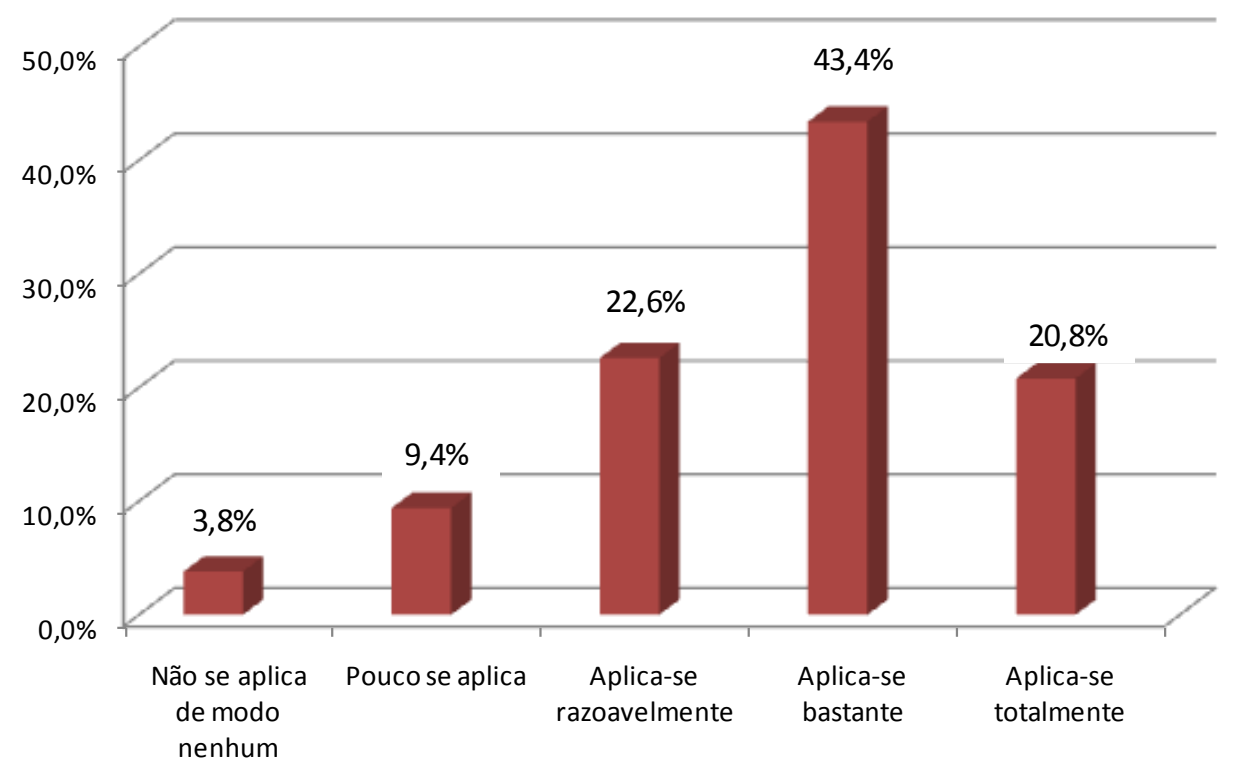

Gráfico 29 - Percentuais do item 5: Os empregados que apresentam ideias inovadoras costumam ser premiados

A partir do Gráfico 30, observa-se que 34\% dos funcionários responderam que o item 16, eventos sociais com distribuição de brindes são comumente realizados para os empregados, aplica-se razoavelmente no dia-a-dia da empresa. 


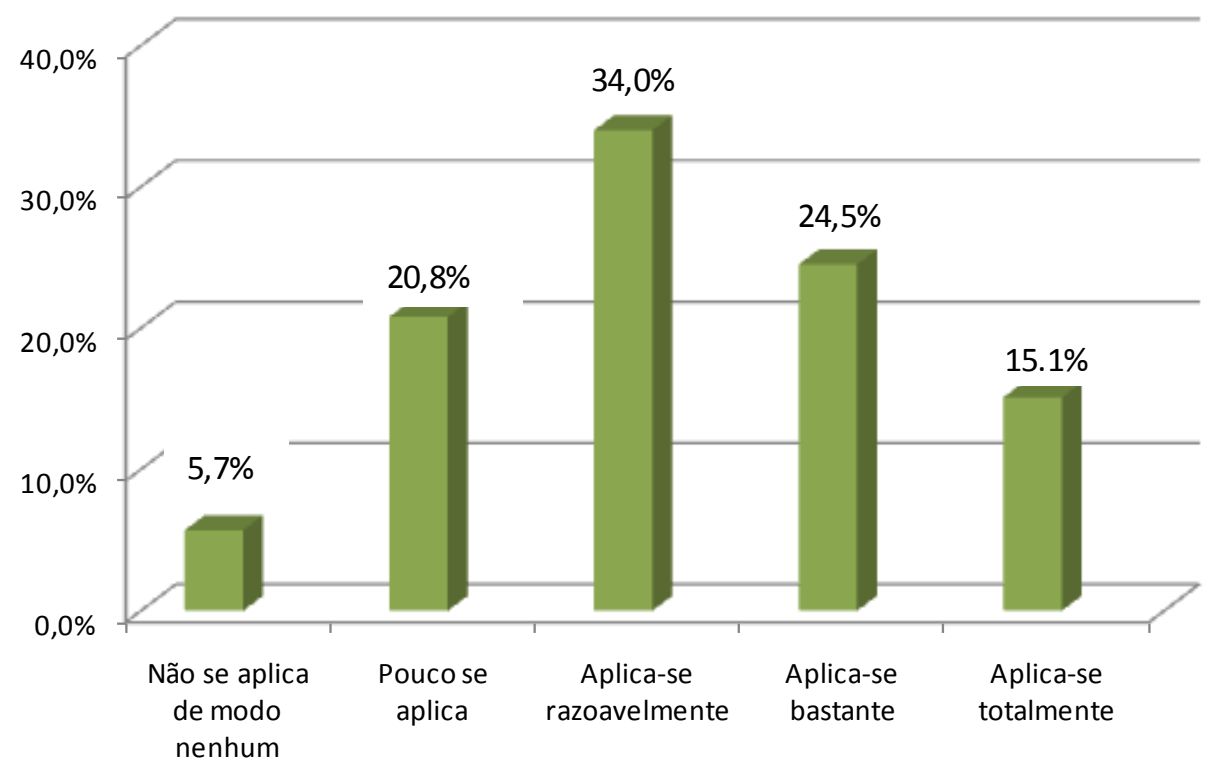

Gráfico 30 - Percentuais do item 16: Eventos sociais com distribuição de brindes são comumente realizados para os empregados

A seguir, no Gráfico 31 relacionado ao item 26 , as inovações costumam ser introduzidas através de programas de qualidade. Do total de funcionários, 47,2\% responderam que a afirmativa se aplica razoavelmente.

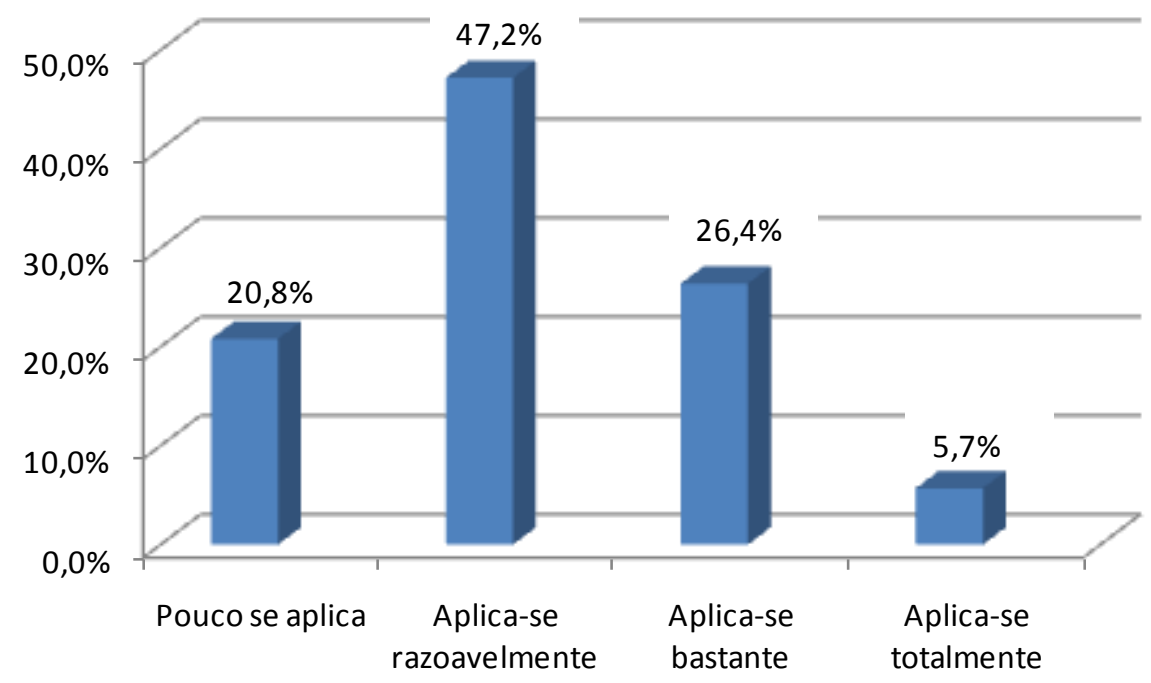

Gráfico 31 - Percentuais do item 26: As inovações costumam ser introduzidas através de programas de qualidade 
4.3.6. Prática: promoção do relacionamento interpessoal

A partir da Tabela 10 é possível observar os itens que mais contribuíram para que a prática Promoção do relacionamento interpessoal alcançasse a média de 3,40 .

Tabela 10 - Médias e desvios padrão dos itens que compõem o fator promoção do relacionamento interpessoal

\begin{tabular}{l|c|c}
\hline \multicolumn{3}{c|}{ PROMOÇÃO DO RELACIONAMENTO INTERPESSOAL } \\
\hline \multicolumn{1}{c|}{ AFIRMAIVAS } & MÉDIA & DESVIO PADRÃO \\
\hline $\begin{array}{l}\text { Item 13: É prática comum a comemoração } \\
\text { dos aniversários pelos empregados. }\end{array}$ & 4,40 & 1,03 \\
\hline $\begin{array}{l}\text { Item 1: Os empregados têm ampla liberdade } \\
\text { de acesso aos diretores. }\end{array}$ & 3,91 & 1,18 \\
\hline $\begin{array}{l}\text { Item 20: As relações entre empregados e } \\
\text { membros do alto escalão são cordiais e } \\
\text { amigáveis. }\end{array}$ & 3,79 & 0,93 \\
\hline $\begin{array}{l}\text { Item 9: Os chefes imediatos são como pais } \\
\text { para os empregados. }\end{array}$ & 2,79 & 1,18 \\
\hline $\begin{array}{l}\text { Item 27: Os empregados se relacionam } \\
\text { como se fossem uma grande família. }\end{array}$ & 2,11 & 0,80 \\
\hline
\end{tabular}

As respostas dadas aos itens 13 e 1 foram as que mais contribuíram para que o fator promoção do relacionamento interpessoal atingisse 3,4\%. Dessa forma, nota-se que a empresa comemora os aniversários dos funcionários e que dá a seus funcionários a liberdade de acesso aos gerentes da empresa. $O$ item 1 mostra que os funcionários percebem uma característica forte da empresa: a liberdade de acesso. Na empresa não há baias nem paredes dividindo o ambiente de trabalho dos gerentes e dos empregados. Esse ambiente estimula as pessoas a conversarem e a questionarem os gerentes quando acharem necessário, além de aumentar o contato com outras áreas.

Grande parte dos funcionários, $66 \%$, respondeu que a prática de comemorar aniversários é totalmente utilizada pela empresa conforme Gráfico 32 que relata as respostas em relação ao item 13: é prática comum a comemoração dos aniversários pelos empregados. 


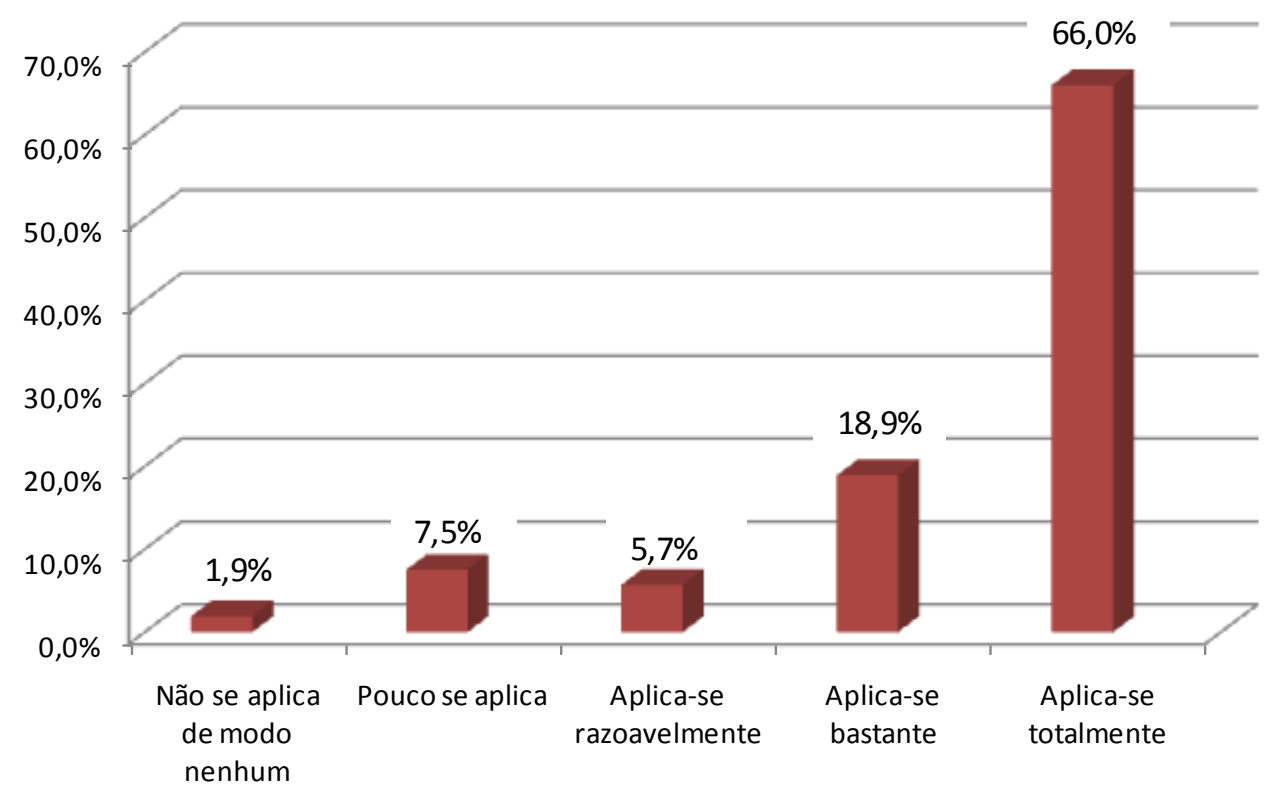

Gráfico 32 - Percentuais do item 13: É prática comum a comemoração dos aniversários pelos empregados

Quanto ao item 1: os empregados têm ampla liberdade de acesso aos diretores, $41,5 \%$ dos funcionários responderam "aplica-se totalmente" na empresa como mostra o Gráfico 33.

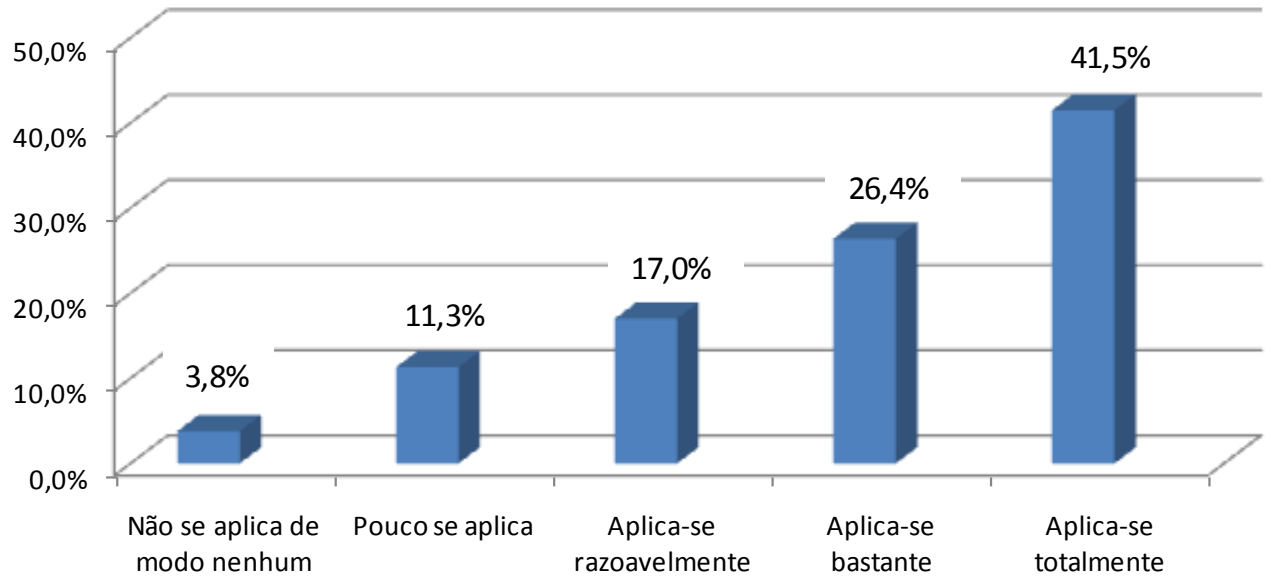

Gráfico 33 - Percentuais do item 1: Os empregados têm ampla liberdade de acesso aos diretores.

O Gráfico 34 mostra que 52,8\% dos funcionários responderam que o item 20: as relações entre empregados e membros do alto escalão são cordiais e amigáveis, aplica-se bastante na empresa. 


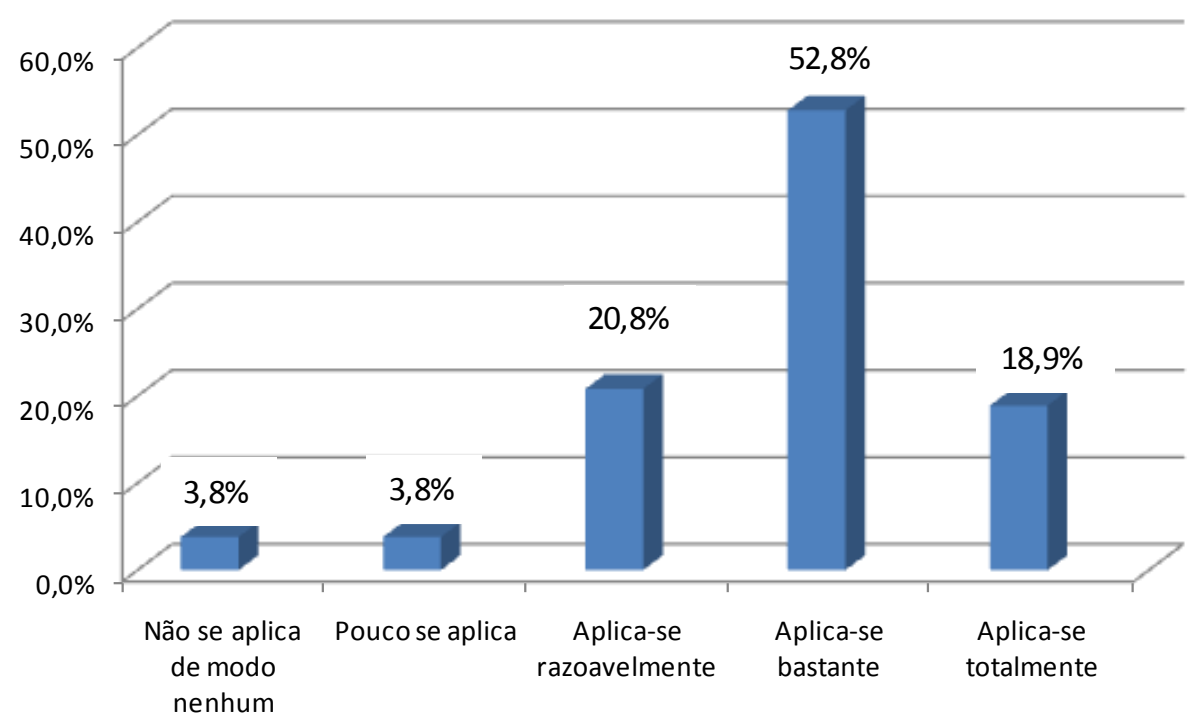

Gráfico 34 - Percentuais do item 20: As relações entre empregados e membros do alto escalão são cordiais e amigáveis

Já o Gráfico 35 mostra que o item 9, os chefes imediatos são como pais para os empregados, aplica-se razoavelmente na empresa com $32,1 \%$ das respostas.

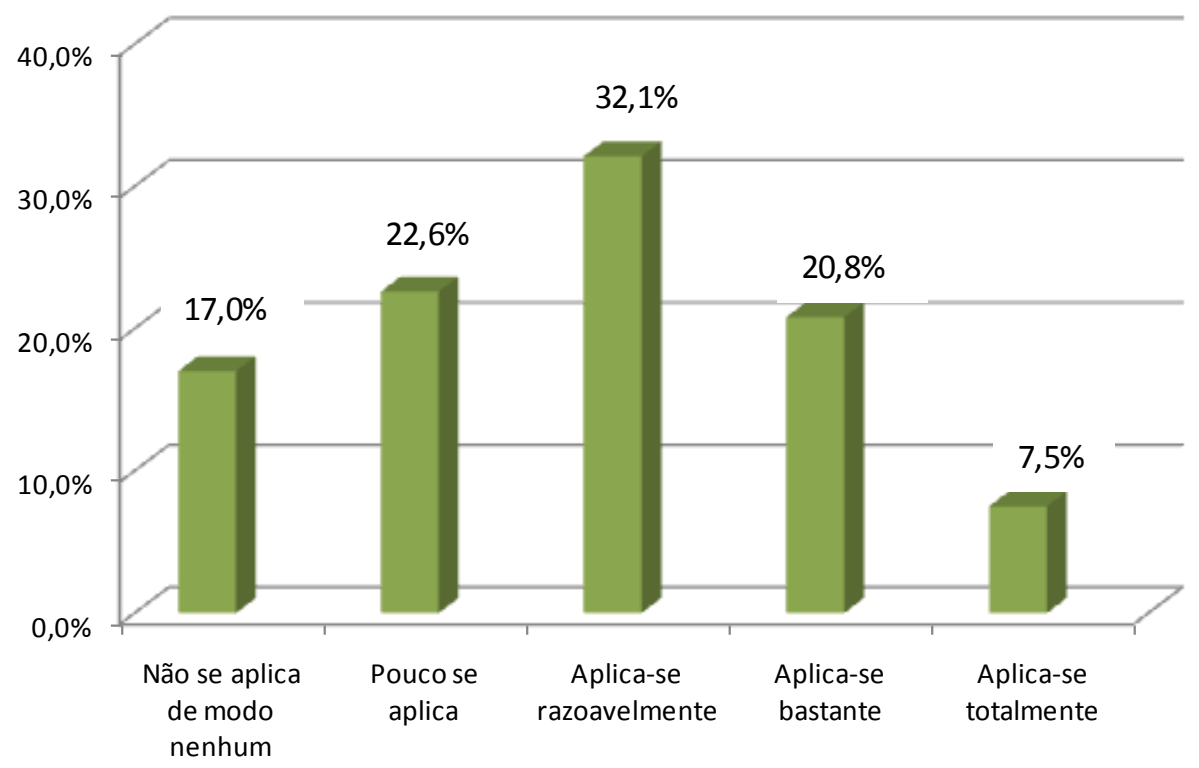

Gráfico 35 - Percentuais do item 9: Os chefes imediatos são como pais para os empregados

Por fim, 41,5\% dos funcionários acreditam que o item 27: os empregados se relacionam como se fossem uma grande família, pouco se aplica na Empresa. A seguir o Gráfico 36 é apresentado. 


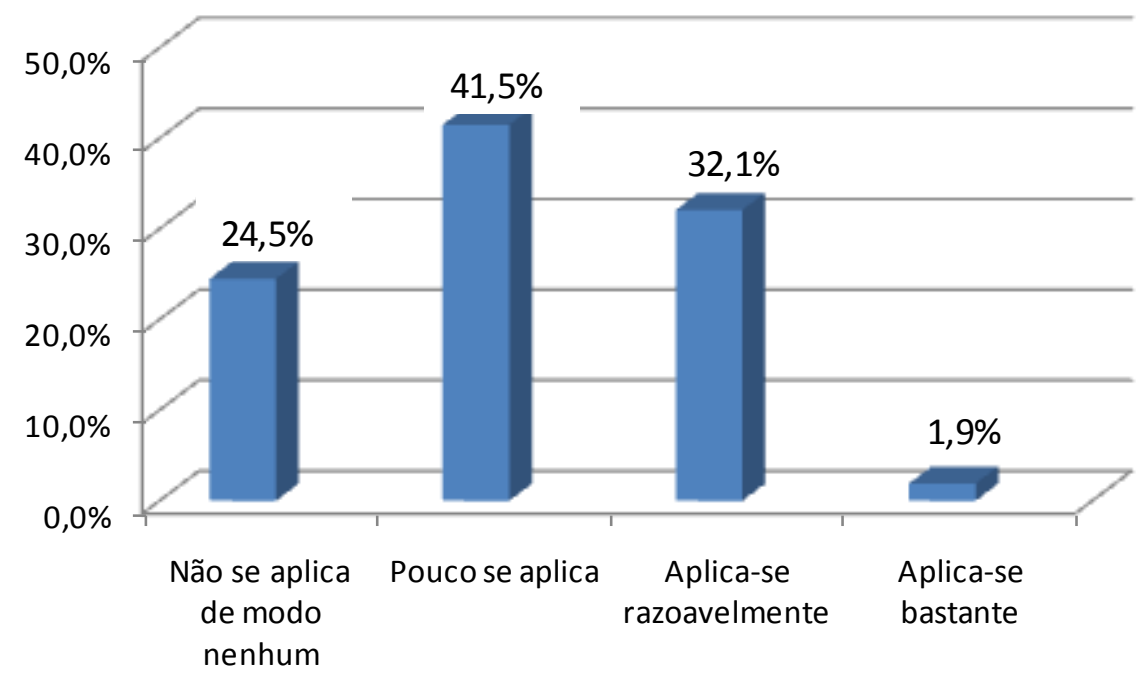

Gráfico 36 - Percentuais do item 27: Os empregados se relacionam como se fossem uma grande família

\subsection{Correlações entre fatores e dados demográficos}

Foram calculadas correlações de Pearson entre os fatores de cultura organizacional e os dados demográficos e, apesar de as correlações não terem sido significativas, percebe-se diferenças de percepção dos fatores de cultura entre as áreas da empresa. Essas diferenças serão apresentadas a seguir.

\subsubsection{Valor: profissionalismo cooperativo}

O Gráfico 37 compara as médias das respostas de cada área para o fator Profissionalismo cooperativo.

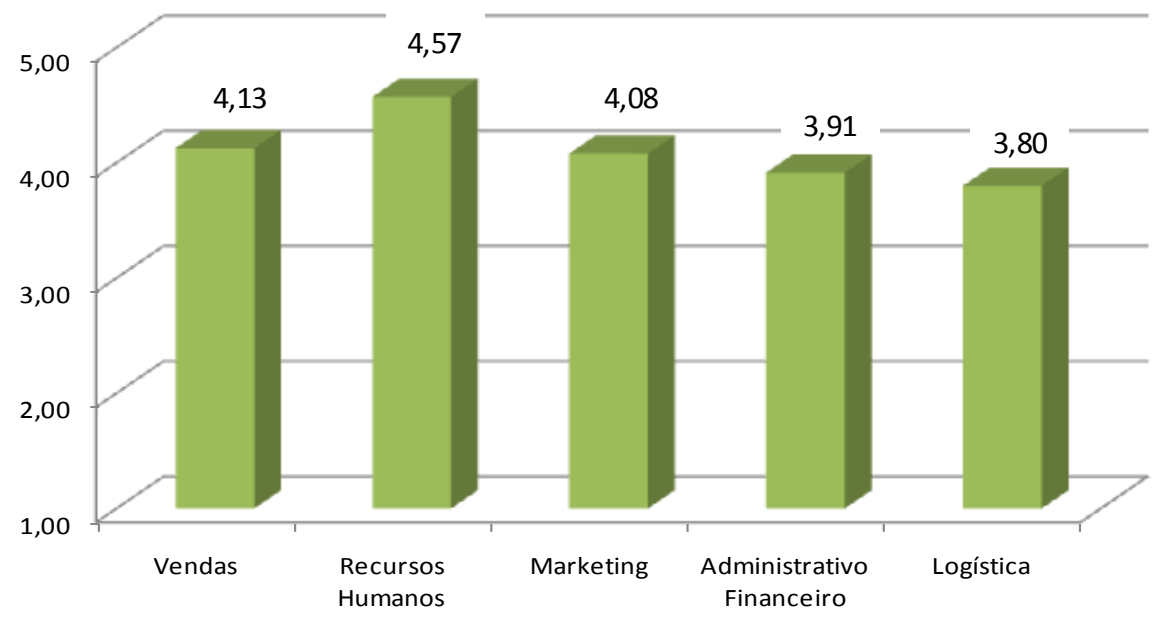

Gráfico 37 - Média das áreas para o fator Profissionalismo cooperativo 
As áreas de Vendas, Recursos Humanos e Marketing foram as que mais apresentaram o valor Profissionalismo cooperativo, tendo suas respostas variado entre "aplica-se bastante" e "aplica-se totalmente". O Administrativo Financeiro e a Logística responderam com maior freqüência que o fator "aplica-se razoavelmente" e "aplica-se bastante".

De acordo com o Gráfico 37, a área que mais apresentou o valor profissionalismo cooperativo foi a área de Recursos Humanos (4,57). Esse resultado pode ser explicado pela natureza das atividades da área e pela função da mesma, pois é relacionada à valorização dos empregados. Ela precisa demonstrar em seu cotidiano eficácia e competência, colaboração e dedicação não somente com a própria área, mas com todos os funcionários para a qual trabalha.

Os funcionários da área de Vendas, mesmo passando grande parte de seu tempo fora da Empresa, foram os segundos a apresentarem valor profissionalismo cooperativo, o que mostra que independentemente de terem contato limitado com o restante da empresa, ele está presente no seu dia-a-dia, guiando as ações. Isso pode ser percebido pela preocupação que essa área tem com as metas da organização e que para superá-las é necessária habilidade, iniciativa e dedicação.

As áreas com menores médias como o Administrativo Financeiro e a Logística têm metas muitas vezes conflitantes com a área fim da empresa e essa situação pode justificar o resultado do Gráfico 37 .

\subsubsection{Valor: satisfação e bem-estar dos empregados}

O Gráfico 38 mostra as médias das respostas de cada área para o fator Satisfação e bem-estar dos empregados.

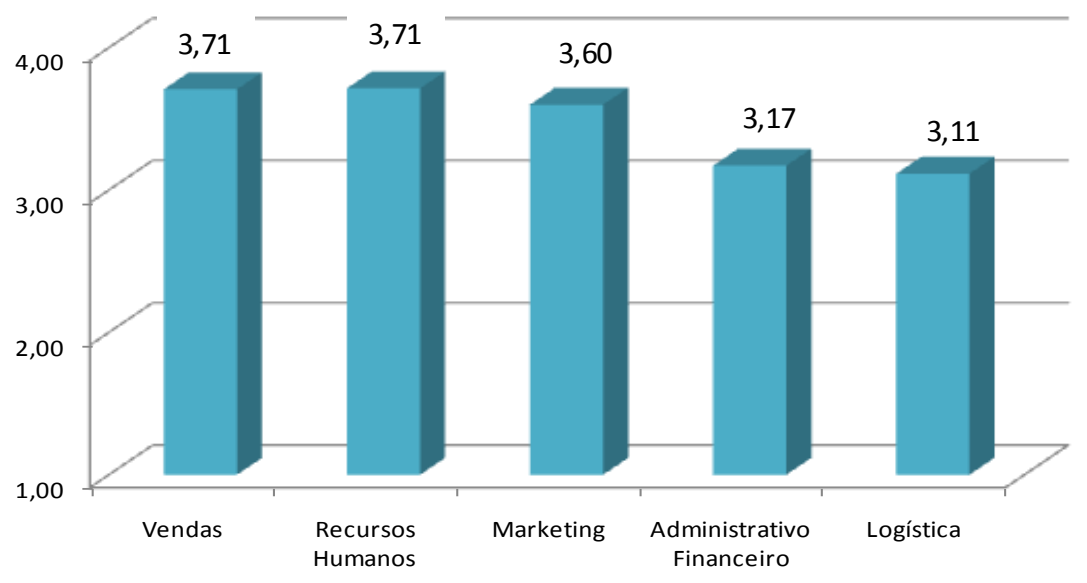

Gráfico 38 - Média das áreas para o fator Satisfação e bem-estar dos empregados 
A área de Vendas e a área de Recursos Humanos foram as que apresentaram maior média, 3,71, variando entre "aplica-se razoavelmente" e "aplicase bastante". Percebe-se, então, que as duas áreas compreendem da mesma forma o valor. Possivelmente porque a área de Recursos Humanos dá suporte às Vendas e é responsável pelo bem-estar, satisfação e motivação dos funcionários.

Como os resultados das outras áreas foram menores, isso significa que elas não percebem da mesma maneira o fator. Sendo assim, a área de Recursos Humanos pode procurar melhorar a satisfação e bem-estar de seus funcionários de modo geral, se preocupando em motivá-los e em tornar o ambiente de trabalho mais prazeroso e agradável. Ela também pode dar maior atenção às demais áreas, principalmente ao Administrativo Financeiro e à Logística.

Parte da equipe da Logística trabalha de madrugada e essa situação dificulta a criação e acompanhamento de ações de bem-estar e satisfação pelo pequeno contato com as outras áreas, principalmente a área de Recursos Humanos.

\subsubsection{Valor: profissionalismo competitivo e individualista}

O Gráfico 39 apresenta as médias das respostas de cada área para o fator Profissionalismo competitivo e individualista.

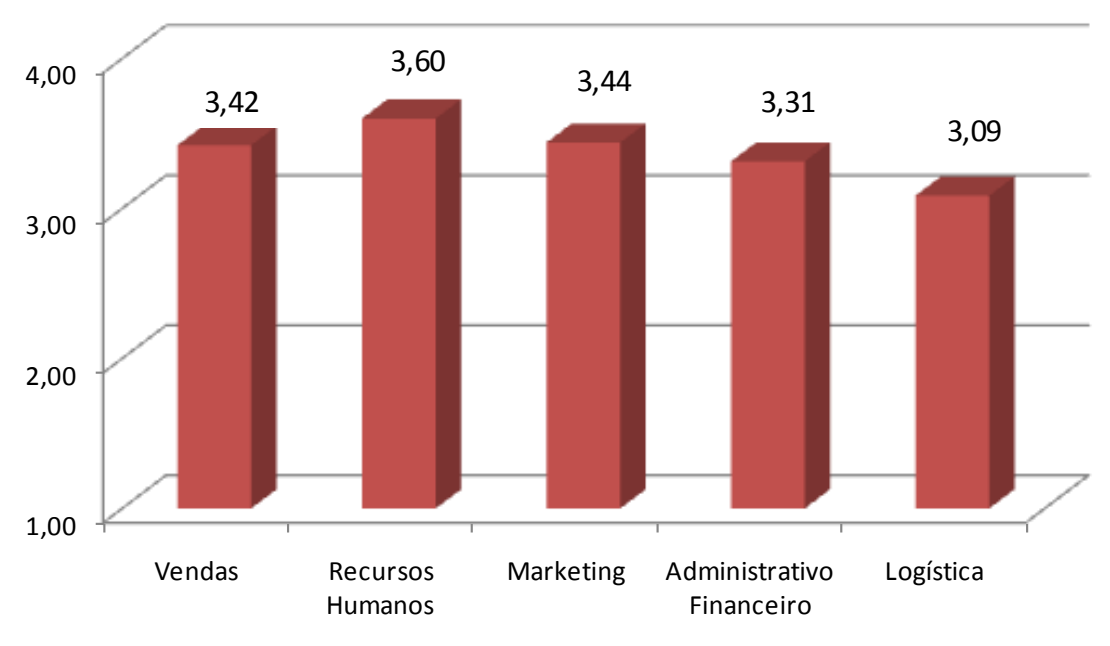

Gráfico 39 - Média das áreas para o fator Profissionalismo competitivo e individualista

Para os itens componentes do valor profissionalismo competitivo e individualista, todas as áreas responderam com maior freqüência "aplica-se razoavelmente". Isso significa que é possível que a empresa valorize o desempenho 
e a eficiência de cada pessoa, de forma individual, na execução das atividades. Além disso, pode ocorrer o fato de que funcionários "passem por cima" de colegas de trabalho. Porém, não é algo desejável pela empresa de acordo com as informações obtidas sobre ela.

A área que obteve maior média foi Recursos Humanos com 3,6. Há possibilidade de o resultado ser explicado pelo acesso que essa área tem a informações sigilosas e pela visão diferenciada que tem de todas as áreas. Assim, ela pode perceber situações em que os funcionários são competitivos e individualistas.

\subsubsection{Prática: integração externa}

O Gráfico 40 apresenta as médias das respostas de cada área para o fator Integração externa.

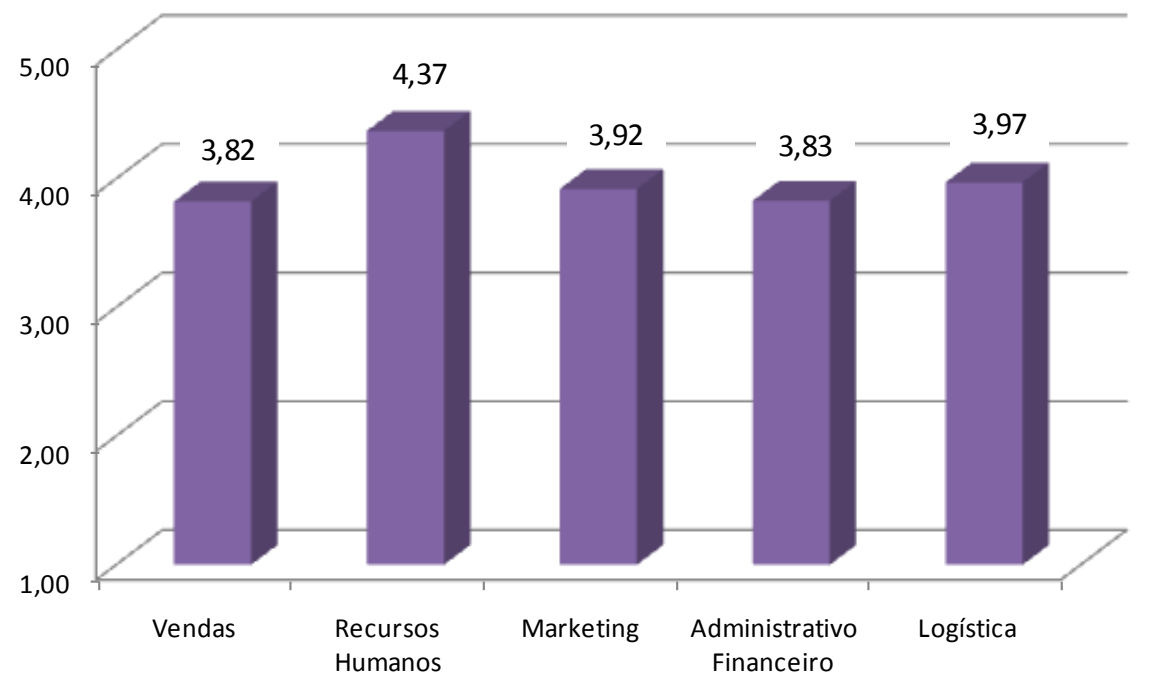

Gráfico 40 - Média das áreas para o fator Integração externa

A área de Recursos Humanos foi a que apresentou a maior média e, portanto, acredita aplicar-se bastante em seu cotidiano o planejamento estratégico e a tomada de decisão por ter bastante contato com gerentes da organização, mesmo não tendo contato direto com o mercado.

A área de Marketing e de Logística apresentaram menores médias que a área de Recursos Humanos, mas ainda assim acreditam que práticas de integração externa se aplicam na realidade vivida por suas áreas, possivelmente pelo fato de terem contato direto com os clientes da empresa. 
As áreas de Vendas e Administrativo Financeiro foram as que apresentaram menores médias. Os funcionários do Administrativo Financeiro executam atividades operacionais e mantêm contato com os clientes apenas por telefone, porém suas atividades não têm como foco o cliente externo, o que explicaria o resultado. Ao analisar o resultado da área de Vendas, percebe-se que os funcionários acreditam que em poucos momentos estão incluídos em ações voltadas para o planejamento estratégico, a tomada de decisão e ao atendimento ao cliente externo. Como a função principal dessa área é atender o cliente, o resultado apresentado pelo Gráfico 40 precisa ser trabalhado pela empresa.

\subsubsection{Prática: recompensa e treinamento}

O Gráfico 41 mostra as médias das respostas de cada área para o fator Recompensa e treinamento.

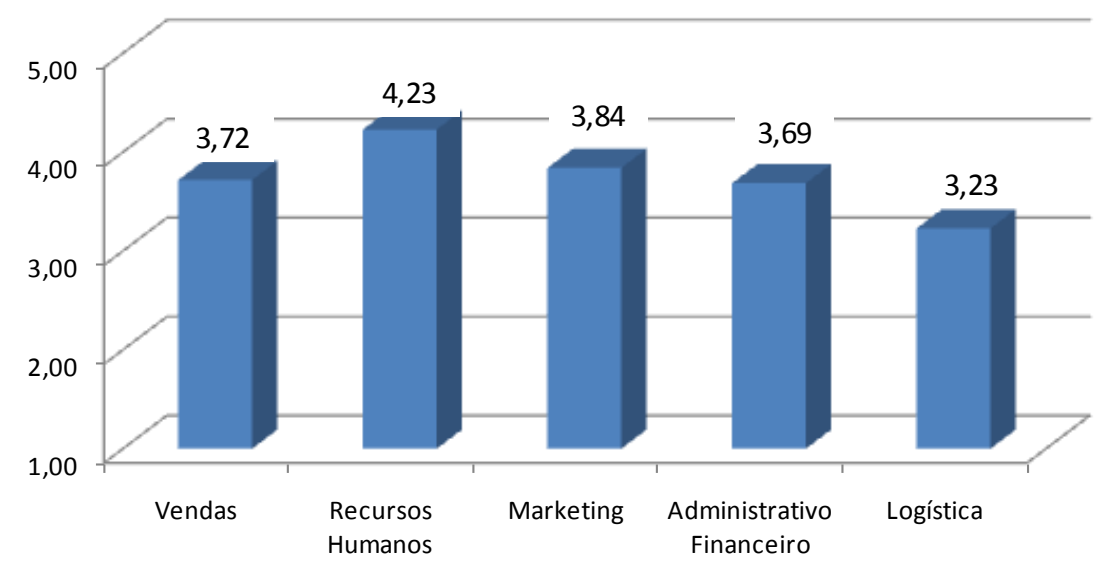

Gráfico 41 - Média das áreas para o fator Recompensa e treinamento

Com média de 4,23, a área de Recursos Humanos foi a que mais percebeu a presença da prática de recompensa e treinamento na organização. É possível concluir que o fato se deve a área ser responsável por esse fator de cultura uma vez que faz parte de sua função. Porém, ao analisar o resultado das outras áreas, notase que elas não percebem a prática tão frequente como a área de Recursos Humanos. Dessa forma, é necessário haver maior foco em treinamentos e ao sistema de recompensa pelo desempenho e atingimento de metas dos funcionários. 


\subsubsection{Prática: promoção do relacionamento interpessoal}

O Gráfico 42 apresenta as médias das respostas de cada área para o fator Promoção do relacionamento interpessoal.

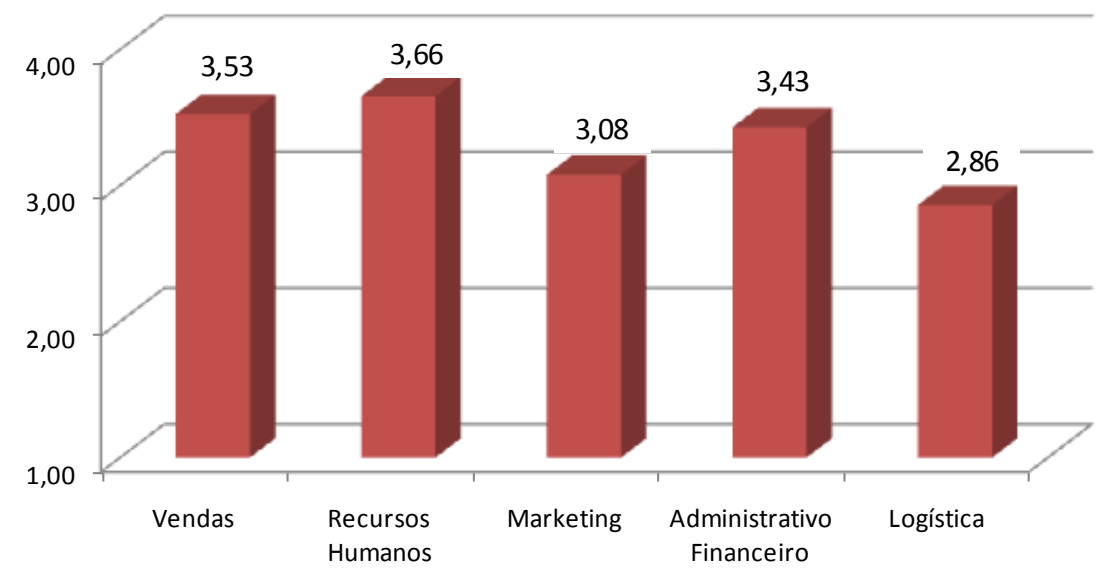

Gráfico 42 - Média das áreas para o fator Promoção do relacionamento interpessoal

As áreas de Vendas, Administrativo Financeiro e, principalmente, Recursos Humanos com a maior média $(3,66)$, foram as que apresentaram maiores médias. Assim conclui-se que elas mantêm práticas que contribuem para a integração da equipe. Como a frequência de resposta variou entre "aplica-se razoavelmente" e "aplica-se bastante", percebe-se que o relacionamento interno das equipes ainda pode melhorar.

As áreas de Marketing e da Logística apresentaram as menores médias, sendo que a maior parte das respostas de funcionários da Logística foi "pouco se aplica" para os itens que compõem a prática promoção do relacionamento interpessoal. A partir desse resultado, há como concluir que não há praticamente nenhuma ação que valorize o relacionamento, a integração e a coesão da equipe da Logística, na percepção dos participantes da pesquisa. Por isso propostas que reuniam toda equipe de forma formal, como reuniões, e informal, como confraternizações ou conversas poderiam ser implantadas para a melhoria do fator.

Percebe-se que os resultados da pesquisa mostraram algumas divergências na percepção da cultura da empresa entre as áreas, apesar de o nível de disseminação não ser diferente pelo fato da natureza do trabalho ser externa ou interna. A partir desses resultados, a organização poderá desenvolver ações para minimizar as divergências atuais. Essa ideia é corroborada por Torquato (1991) que 
destaca a necessidade de identificar a cultura interna para que possam ser tomadas decisões em relação aos problemas existentes. Além disso, de acordo com as informações retiradas do site, é possível observar o quanto o consenso sobre a cultura organizacional é importante para a Empresa e que pessoas que não compartilhem essa cultura não permanecem por muito tempo na organização. Torres (2008) valida a observação por acreditar que quanto maior o grau de partilha entre os funcionários, mais forte e consensual será a cultura.

A empresa apresenta alguns comportamentos que são esperados de seus funcionários, normas que devem ser seguidas por todos diariamente e ideologias que todos devem ter, ou seja, ela apresenta os três componentes da cultura para Katz e Kahn (1978 apud TAMAYO, 2000, p. 291): os papéis, as normas e os valores.

Por fim, é perceptível a existência de práticas como a de Integração externa e valores como o Profissionalismo cooperativo que são mais disseminados na Empresa. Isso mostra que conforme Hofstede et al. (1990 apud FERREIRA; ASSMAR, 2008, p.127) destaca, a cultura organizacional pode se manifestar por meio de valores e práticas e ainda que os líderes são responsáveis por moldar a cultura, o que corrobora com a crença da Empresa de que o exemplo pessoal do líder é muito importante para equipe. 


\section{CONSIDERAÇÕES FINAIS}

Cultura organizacional é um tema relevante para qualquer empresa, pois ela reflete os valores e as práticas utilizadas e isso a identifica e a diferencia das demais. Ela também impacta no desempenho do indivíduo e do grupo e, por isso, é importante que todos os membros da organização entendam, possuam e compartilhem essa cultura. Todos os funcionários de uma organização contribuem constantemente com a caracterização da cultura de uma empresa, pois seus valores ajudam a formar uma cultura maior. Porém, nem sempre ela é percebida por todos da mesma forma e, quando isso acontece, os funcionários não correspondem às expectativas por não saberem como agir. A organização, então, deve procurar disseminar sua cultura aumentando o conhecimento de seus funcionários sobre a empresa e/ou propor práticas diárias e moldar a cultura, a fim de disseminar os valores pretendidos.

O objetivo principal deste trabalho foi comparar se os funcionários da empresa em estudo percebiam a cultura da mesma forma, mesmo muitos deles exercendo suas atividades, na maior parte do seu dia, fora da empresa, interagindo com o ambiente externo a ela.

Ao realizar a pesquisa foram encontradas algumas dificuldades. Primeiramente, quanto à amostra, o número de questionários respondidos foi bastante inferior ao desejável. Essa limitação ocorreu porque o dia-a-dia da empresa é corrido, muitas pessoas não podiam responder o questionário no momento da solicitação. Quanto à área de Vendas (área fim), os funcionários passavam apenas uma hora e meia trabalhando internamente na Empresa. Já parte dos funcionários da Logística, como conferentes, trabalhavam de madrugada, o que também dificultou a aplicação do questionário. Por mais que não tenha sido possível realizar a pesquisa com a amostra desejada, os resultados são relevantes para Empresa e podem ser utilizados para conhecer os pontos fortes e os pontos fracos de sua cultura. Os resultados mostram as percepções de parte dos funcionários, mas norteiam as ações para disseminar a cultura de forma ainda mais efetiva pela empresa.

Outra dificuldade encontrada foi a não liberação por parte da empresa de documentos internos. Isso limitou a análise dos resultados, pois ela foi realizada 
apenas com informações do site. Além disso, a Empresa não autorizou a divulgação de seu nome, limitando, assim, a quantidade de informações que poderiam ser divulgadas para caracterizá-la, já que sua identidade não pode ser revelada. Com isso, o objetivo específico "analisar os pontos relevantes da cultura da empresa que são divulgados por meio da internet' foi atingido, mas os outros dois - caracterizar a área fim da empresa e suas áreas de suporte e caracterizar os fatores que compõem a cultura organizacional na empresa objeto de estudo - foram atingidos em parte. Não foi possível detalhar as atividades executadas diariamente pelas áreas e nem analisar os documentos e as apresentações sobre a cultura que a empresa desenvolveu e que seriam relevantes para esse estudo.

Dos fatores de cultura organizacional analisados, o valor mais presente na empresa é o Profissionalismo cooperativo, ou seja, a Empresa valoriza os funcionários que executam suas atividades com eficácia e competência. Além disso, valoriza quem demonstra colaboração, dedicação ao trabalho, profissionalismo e iniciativa contribuindo para o alcance das metas. E a prática mais presente é a Integração externa, portanto práticas como planejamento estratégico, atendimento de clientes externos e práticas para tomada de decisão são as mais utilizadas.

Razoavelmente presentes estão o valor Satisfação e bem-estar dos empregados e a prática Recompensa e treinamento. O primeiro significa que a empresa se preocupa com a satisfação e motivação dos funcionários, mas isso ainda pode ser melhorado de forma a tornar o local de trabalho mais agradável e prazeroso de se trabalhar. E a segunda mostra que a empresa não está treinando e recompensando os funcionários suficientemente, apesar dela desejar que essa prática faça parte de sua cultura.

A partir dos resultados da pesquisa, observou-se que a prática que a empresa precisa mais trabalhar é a Promoção do relacionamento interpessoal, pois é a menos presente na organização, principalmente nas áreas de Marketing e da Logística. São necessárias ações que valorizem as relações interpessoais e que satisfaçam os empregados. Assim poderá contribuir para uma maior coesão entre os funcionários e tendo em vista que a colaboração é um ponto importante da cultura da empresa, essa prática se torna bastante relevante.

O valor Profissionalismo competitivo e individualista também se mostrou pouco presente na empresa. Apesar de a empresa valorizar a meritocracia, o que pode contribuir para a ocorrência de competição para atingir metas, ela não valoriza 
o pensamento individualista, pois parte do princípio que todos devem se ajudar para que o desempenho da equipe seja excelente.

Quanto às áreas da Empresa, Recursos Humanos foi a que mostrou ter os fatores de cultura mais presentes no seu dia-a-dia. Muitas ações que compõem os fatores são de responsabilidade dessa área e possivelmente por essa razão chegouse a esse resultado. Porém, nem todas as áreas percebem a presença dos valores e das práticas da mesma maneira que Recursos Humanos e esse pode ser um ponto de atenção a ser trabalhado pela Organização.

A segunda área a apresentar os fatores foi a de Vendas e as que tiveram resultados mais divergentes foram o Administrativo Financeiro e a Logística. A partir desse resultado, percebe-se que, por mais que a área de Vendas execute muitas atividades fora da organização e sem contato direto na maior parte do tempo com a empresa, ela apresenta os mesmos valores e práticas de cultura (em alguns casos até mais) que outras áreas que executam atividades internas. Sendo assim, as ações da empresa estão sendo efetivas. Os vendedores entendem a cultura da mesma forma como a organização deseja e, por conseqüência, demonstram no mercado essa cultura e, assim, fazem com que a empresa seja reconhecida e se diferencie das concorrentes.

Por fim, conclui-se que a Empresa possui muitos pontos relevantes na sua cultura, mas que nem todos são disseminados de forma a alcançar todas as áreas e cargos. Algumas práticas são bastante percebidas pelos funcionários e outras não. As que não são tão percebidas precisam ser trabalhadas para que sejam incorporadas no cotidiano das pessoas. E quanto aos valores, que são mais difíceis de trabalhar, além de criar ações para disseminá-los na Empresa, é importante que as contratações feitas sejam de pessoas que apresentem pensamentos, aspirações e valores semelhantes aos da empresa, ou seja, que tenham o perfil da Organização.

É importante também que sejam realizados mais estudos sobre o tema cultura, na empresa, com uma amostra maior e probabilística para que se verifique se há correlação significativa entre as variáveis cultura e áreas de trabalho. Outras variáveis podem ser analisadas em relação à cultura organizacional, a fim de propiciar o desenvolvimento de ações gerenciais voltadas para o desenvolvimento da cultura almejada pela Empresa. 


\section{REFERÊNCIAS}

BARNEY, J. Organizational culture: can it be a source of sustained competitive advantage? Academy of Management Review, v. 11, n. 3, p. 656-665, 1986.

CANDIDO, T.E.; JUNQUEIRA, L.A.P. Influência da Cultura Organizacional na Gestão e Compartilhamento do Conhecimento. eGesta - Revista Eletrônica de Gestão de Negócios, v.2, n.1, p.5-24, jan./mar. 2006. Disponível em:<http://www.unisantos.br/mestrado/gestao/egesta/artigos/52.pdf>. Acesso em: 04 abr. 2009.

FERREIRA, M.C. et al. Desenvolvimento de um instrumento brasileiro para avaliação da cultura organizacional. Estudos de Psicologia, Natal, v.7, n.2, p. 271-280, jul/dez. 2002.

FERREIRA, M.C.; ASSMAR, E.M.L. Cultura organizacional. In: SIQUEIRA, M.M. et al. (Orgs.). Medidas do comportamento organizacional: ferramentas de diagnóstico e de gestão. Porto Alegre: Artmed, 2008. cap. 7.

FLEURY, M.T.L. et al. Cultura e poder nas organizações. 1.ed. São Paulo: Atlas, 1989.

MOORHEAD, G. Organizational behavior. 8.ed. Boston: Houghton Mifflin, 2007.

MORGAN, G. A criação da realidade social: as organizações vistas como culturas. In: . Imagens da organização. 1.ed. São Paulo: Atlas, 1996. cap.5.

PIRES, J.C.S.; MACÊDO, K.B. Cultura organizacional em organizações públicas no Brasil. RAP, Rio de Janeiro, v.40, n.1, p. 81-105, jan./fev. 2006.

ROBBINS, S.P. Comportamento Organizacional. 11.ed. São Paulo: Pearson Prentice Hall, 2005.

SILVA, N.; ZANELLI, J.C. Cultura organizacional. In: ZANELLI, J.C.; BORGESANDRADE, J.E.; BASTOS, A.V.B. (Orgs). Psicologia, organizações e trabalho no Brasil. Porto Alegre: Artmed, 2004. Cap.13. 
TAMAYO, A.; MENDES, A.M.; PAZ, M.G.T. Inventário de valores organizacionais. Estudos de Psicologia, v. 5, n. 2, p. 289-315, 2000.

TORQUATO, G. Cultura, poder, comunicação e imagem: fundamentos da nova empresa. São Paulo: Pioneira, 1991.

TORRES, L.M.L. (Re)Pensar a cultura e a formação em contexto de trabalho: tendências, perspectivas e possibilidades de articulação. Sociologias, Porto Alegre, n.19, p.180-211, jan./jun. 2008. Disponível em:< http://www.scielo.br/pdf/soc/n19/a09n19.pdf >. Acesso em: 04 abr. 2009.

VERGARA, S.C. Começando a definir a metodologia. In: Projetos e Relatórios de Pesquisa em Administração. 6.ed. São Paulo: Atlas, 2005. Cap. 4. 


\section{ANEXO A: Instrumento Brasileiro para Avaliação da Cultura Organizacional (IBACO)}

\section{PESQUISA}

Esse questionário é parte de um trabalho de conclusão do curso de Administração da Universidade de Brasília. Gostaria de contar com a sua colaboração para preenchimento do mesmo.

Não haverá identificação dos participantes da pesquisa, pois os dados serão analisados de forma conjunta. Não há respostas certas ou erradas.

Responda por favor as 30 afirmativas, não deixando nenhuma em branco, de acordo com a escala abaixo.

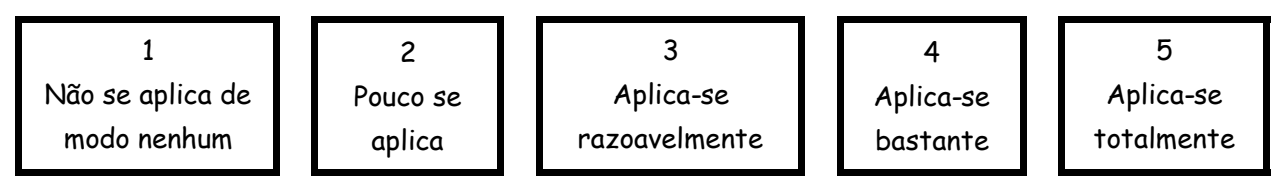

Sua resposta deve refletir o que de fato acontece na empresa e não a sua opinião pessoal ou grau de satisfação com o que ocorre.

Na empresa em que eu trabalho...

1. Os empregados têm ampla liberdade de acesso aos diretores.

2. O atendimento às necessidades do cliente é uma das metas mais importantes.

3. As necessidades pessoais e o bem-estar dos funcionários constituem uma preocupação constante da empresa.

4. Persegue-se a excelência de produtos e serviços como forma de satisfazer aos clientes.

5. Os empregados que apresentam idéias inovadoras constumam ser premiados.

6. Investe-se no crescimento profissional dos empregados.

7. O acompanhamento e atendimento das necessidades dos clientes é feito constantemente.

8. Mantêm-se relações amigáveis com os clientes.

9. Os chefes imediatos são como pais para os empregados.

10. Os empregados recebem treinamento para poderem desenvolver a criatividade.

11. Os empregados são premiados quando apresentam um desempenho que se destaca dos demais.

12. Programas para aumentar a satisfação dos empregados são regularmente desenvolvidos.

13. É prática comum a comemoração dos aniversários pelos empregados.

14. A preocupação do empregado com a qualidade de seu serviço é bem vista.

15. As inovações são em geral introduzidas para atender às necessidades do mercado.

16. Eventos sociais com distribuição de brindes são comumente realizados para os empregados.

17. O esforço e a dedicação ao trabalho são qualidades bastante apreciadas.

18. Programas destinados a melhorar o bem-estar dos empregados são implementados e testados.

19. O profissionalismo dos empregados é visto como uma grande virtude.

20. As relações entre empregados e membros do alto escalão são cordiais e amigáveis.

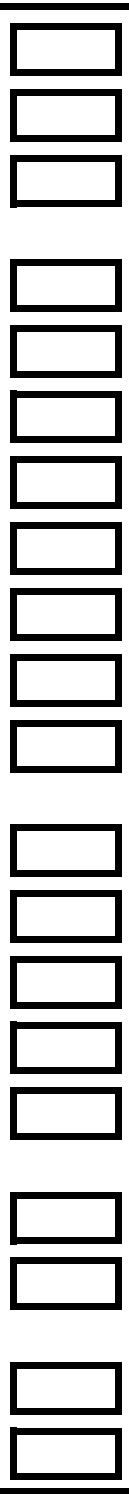


Responda as afirmativas de acordo com a escala abaixo.

\begin{tabular}{|c|c|}
\hline $\begin{array}{c}\text { Não se aplica de } \\
\text { modo nenhum }\end{array}$ & $\begin{array}{c}2 \\
\text { Pouco se } \\
\text { aplica }\end{array}$ \\
\hline
\end{tabular}

\begin{tabular}{c}
\hline 3 \\
Aplica-se \\
razoavelmente \\
\hline
\end{tabular}

\begin{tabular}{|c|}
\hline 4 \\
Aplica-se \\
bastante \\
\hline
\end{tabular}

\begin{tabular}{|c|}
\hline 5 \\
Aplica-se \\
totalmente \\
\hline
\end{tabular}

$\mathrm{Na}$ empresa em que eu trabalho...

21. A preocupação em superar as dificuldades do dia-a-dia é vista como de grande valor.

22. Os empregados que demonstram dedicação e espírito de colaboração são os melhores modelos a serem seguidos.

23. Somente os bons empregados recebem benefícios que lhes garantem um melhor bem-estar.

24. A criatividade é um dos requisitos básicos para a ocupação de cargos gerenciais.

25. O crescimento profissional é considerado indispensável à permanência do empregado na casa.

26. As inovações costumam ser introduzidas através de programas de qualidade.

27. Os empregados se relacionam como se fossem uma grande família.

28. Os empregados costumam ser premiados quando alcançam metas pré-estabelecidas.

29. A competição é valorizada, mesmo que de forma não sadia, porque o objetivo maior da empresa é a produtividade e lucro.

30. A competição é vista como indispensável à obtenção de bons resultados.

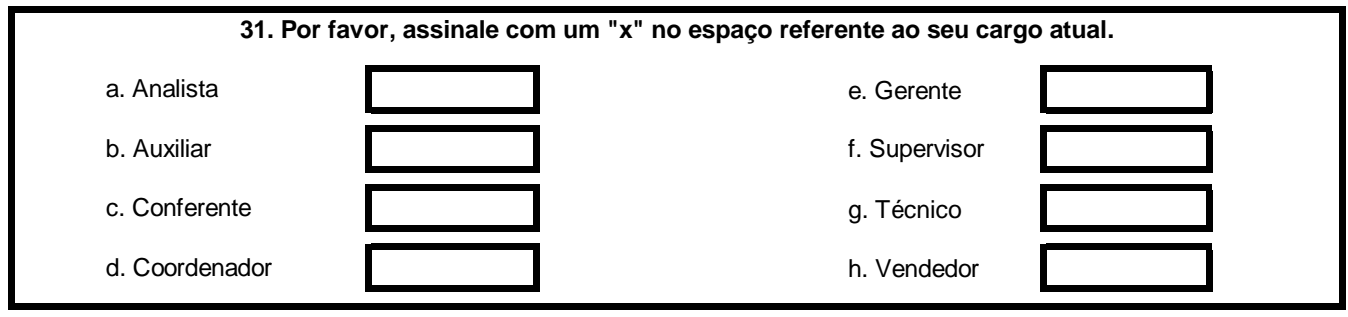

Assinale no espaço em branco a letra correspondente a suas informações.

32. Gênero:

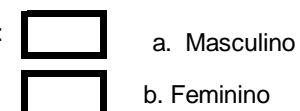

33. Faixa Etária:

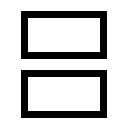

a. Abaixo de 20 anos

b. De 20 a 30 anos

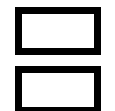

c. Entre 30 e 40 anos

d. Acima de 40 anos

34. Tempo de Empresa:

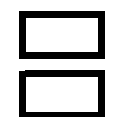

a. Abaixo de 1 ano

b. De 1 a 2 anos

c. Entre 2 e 4 anos

35. Tempo no cargo atual:

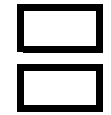

a. Abaixo de 1 ano

b. De 1 a 2 anos

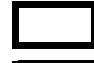

d. Acima de 4 anos

36. Escolaridade:

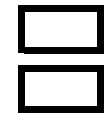

a. Ensino Médio

c. Pós-Graduação

c. Entre 2 e 4 anos

d. Acima de 4 anos

Autoria: Ferreira et al. (2002), com adaptações. 